\title{
SOLOS E BIOCONSTRUÇÕES: MORFOLOGIA E GEOQUÍMICA DOS CUPINZEIROS E DOS SOLOS ASSOCIADOS NA REGIÃO DE HUMAITÁ (SUL DO ESTADO DO AMAZONAS)
}

\section{MÁRCIA TOFFANI SIMÃO SOARES}

Engenheira Agrônoma

Orientador: Prof. Dr. ADOLPHO JOSÉ MELFI

Dissertação apresentada à Escola Superior de Agricultura "Luiz de Queiroz", Universidade de São Paulo, para obtenção do título de Mestre em Agronomia, Área de Concentração: Solos e Nutrição de Plantas.

PIRACICABA

Estado de São Paulo - Brasil

Dezembro - 1999 
Dados Internacionais de Catalogação na Publicação (CIP)

DIVISÃO DE BIBLIOTECA E DOCUMENTAÇÃO - Campus "Luiz de Queiroz"/USP

Soares, Márcia Toffani Simão

Solo e bioconstruçōes: morfologia e geoquímica dos cupinzeiros e dos solos associados na região de Humaitá (sul do Estado do Amazonas) / Márcia Toffani Simão Soares. - Piracicaba, 1999.

$129 \mathrm{p}$.

Dissertação (mestrado) - - Escola Superior de Agricultura Luiz de Queiroz, 1999. Bibliografia

1. Biologia do solo 2. Ciclagem de nutriente 3. Ciclo biogeoquímico 4. Cupim-demontículo 5. Ecologia do solo 6. Fertilidade do solo 7. Morfologia do solo 8. Relação inseto-ecossistema I. Titulo

CDD 631.46

"Permitida a cópia total ou parcial deste documento, desde que citada a fonte - O Autor" 


\begin{abstract}
À Deus, que nos legou este infindável campo de estudos e de cuidados- o Planeta Terra
\end{abstract}

Aos meus pais, Melchor e Amiltes, os maiores colaboradores de minhas realizações e felicidades

Dedico. 


\section{AGRADECIMENTOS}

Apenas palavras não são suficientes para manifestar meu sentimento de gratidão a tantos que contribuíram para a realização deste trabalho. Alguns nomes são imprescindíveis serem citados:

Ao meu orientador, Prof. Dr. Adolpho José Melfi, que confiou-me este trabalho e a oportunidade de amadurecer cientificamente, profissionalmente e como ser humano.

Ao Pesquisador Dr. Vincent Eschenbrenner (CENA/USP e IRD (ex ORSTOM), pelos ensinamentos transmitidos nestes últimos 2 anos, com paciência e dedicação, e por ter me guiado nos domínios do conhecimento científico.

Aos pesquisadores do Núcleo de Pesquisa em Geoquímica da Litosfera (NUPEGEL/USP), em especial à Professora Célia Regina Montes-Lauar (Depto. Solos e Nutrição de Plantas, ESALQ/USP), e ao Dr. Boris Volkoff (IRD - ex ORSTOM), pelo apoio logístico, sugestões e atenção nos momentos de dúvidas.

Aos Professores Miguel Cooper (Depto. Solos e Nutrição de Plantas, ESALQ/USP), Carlos Tadeu S. Dias (Depto. de Matemática e Estatística, ESALQ/USP) e ao doutorando Álvaro Luís Mafra (Depto. Solos e Nutrição de Plantas, ESALQ/USP), pelas valiosas contribuições a este trabalho.

À Coordenação do Curso de Pós Graduação em Solos e Nutrição de Plantas, por possibilitar a realização do Mestrado.

À CAPES e ao IRD (ex ORSTOM) pelo auxílio financeiro.

Aos funcionários da ESALQ (são tantos os quais sou grata!), em especial aos da Biblioteca Central e do Depto. de Solos e Nutrição de Plantas (Bete, Vladimir, Luciano, "Silva", Márcia, Célia, ...), pela convivência sempre harmoniosa e pelo apoio e auxílio nas mais diversas formas.

Aos amigos da Vila Estudantil, Graduação e Pós Graduação, por todos os momentos de alegria que compartilhamos.

Aos funcionários do Laboratório de Biogeoquímica do Solo (CENA), por toda a atenção despendida. 
À Clotilde Maria Batochio, Ney Pinheiro Sampaio e Paulo Sebastião, pelo apoio técnico, pelo carinho recebido, e pelos valiosos momentos vividos em nosso ambiente de trabalho e estudo.

Aos meus colegas de curso, companheiros de trincheiras, cadernos e sorrisos.

Aos amigos Aderbal A. Rocha, Celso Graminha, Norberto C. Noronha e Sonia M. Carpinelli, por não deixarem apagar a sede da descoberta, a partilha do conhecimento e da AMIZADE. 


\section{SUMÁRIO}

RESUMO

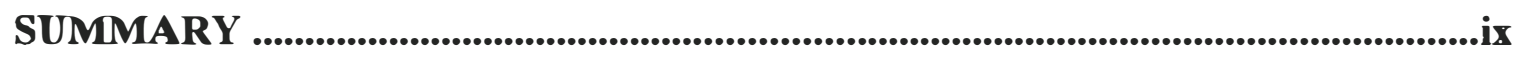

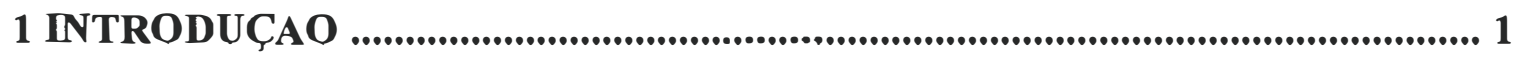

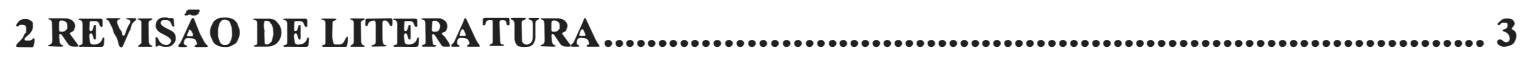

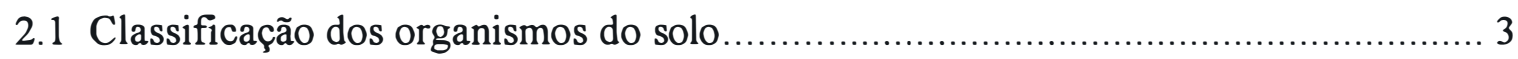

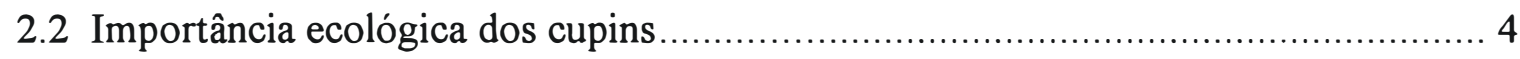

2.3 Cupins, matéria orgânica e ciclagem de nutrientes....................................... 5

2.4 Relação entre propriedades químicas dos cupinzeiros e solos associados................ 5

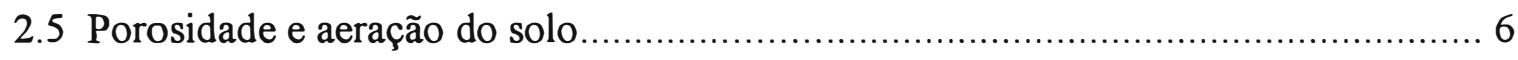

2.6 Individualização de partículas - a formação de pelotas........................................ 6

2.7 Alterações texturais, e diferenciação de material .............................................. 7

2.8 Contribuição ao empobrecimento em argila do horizonte superficial do solo.......... 8

2.9 Alterações morfológicas dos cupinzeiros e do solo ......................................... 8

3 MATERIAL E MÉTODOS...........................................................................10

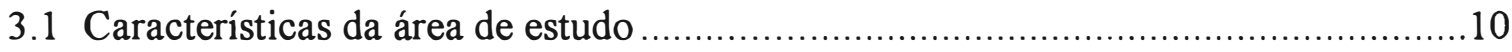

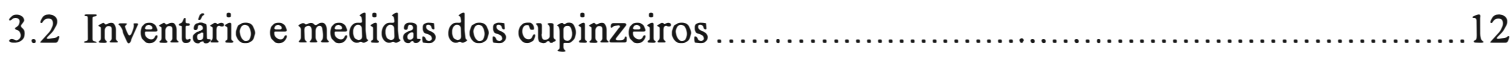

3.3 Escolha dos cupinzeiros para determinação das características morfológicas, fisicas,

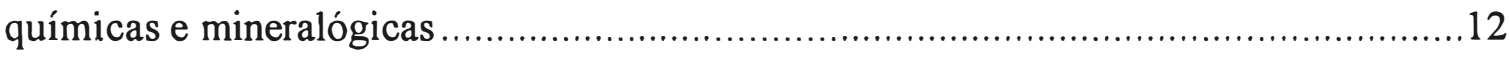

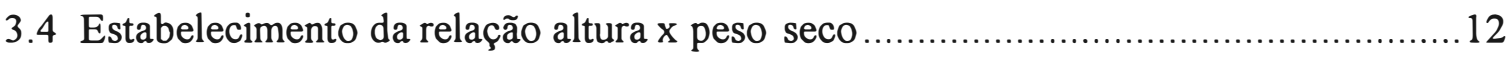

3.5 Escolha dos cupinzeiros para determinação das características morfológicas, fisicas,

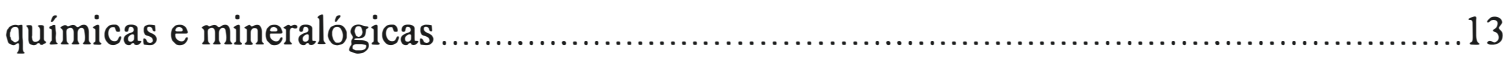

3.5.1 Coleta de amostras homogeneizadas dos cupinzeiros (amostras do tipo $\Sigma$ )..........13

3.5.2 Coleta de amostras das estruturas isoladas dos cupinzeiros e das camadas do solo contíguo a este

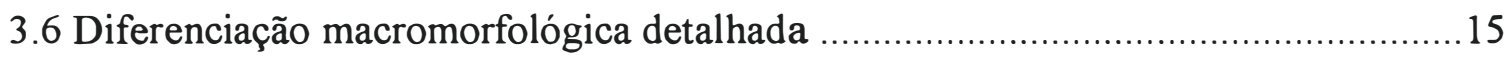

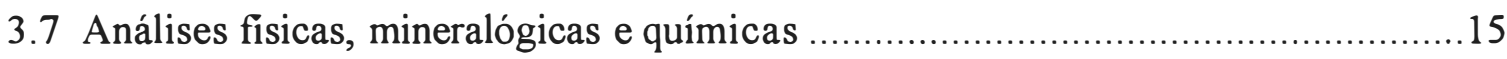




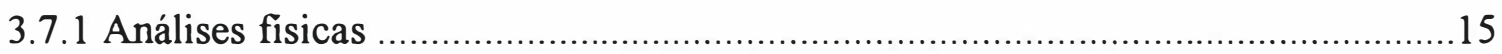

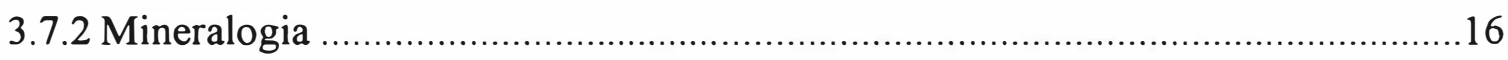

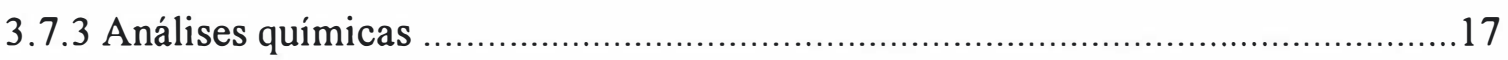

3.7.4 Microscopia eletrônica de varredura (MEV) e microanálise ...............................18

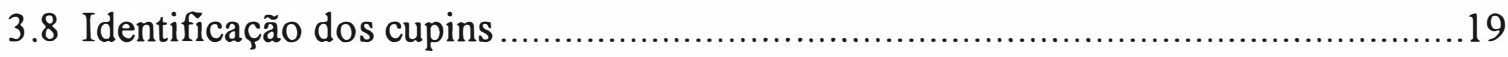

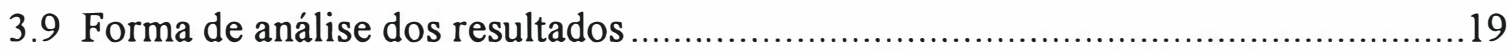

4 RESULTADOS ...........................................................................................................20

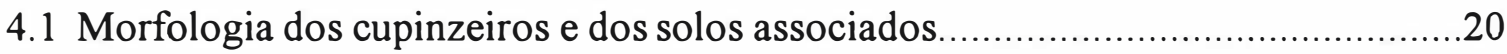

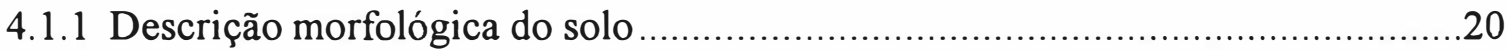

4.1.1.1 Diferenciação macromorfológica vertical detalhada ……..............................21

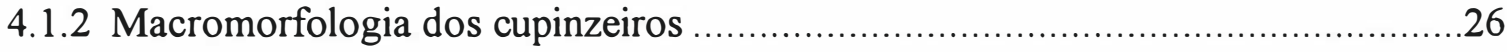

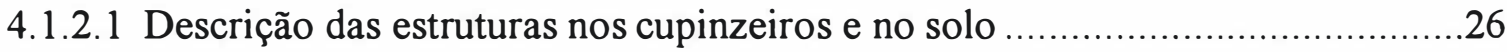

4.1.3 Meso e micromorfologia dos cupinzeiros - tipologia das deposições dos

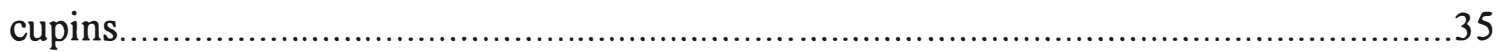

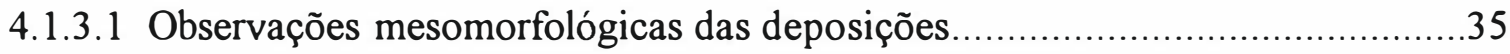

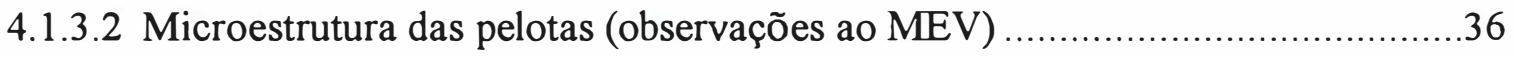

4.2 Dados para a estimativa dos estoques de elementos no solo e nos cupinzeiros .......37

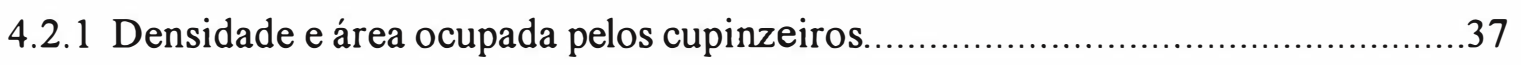

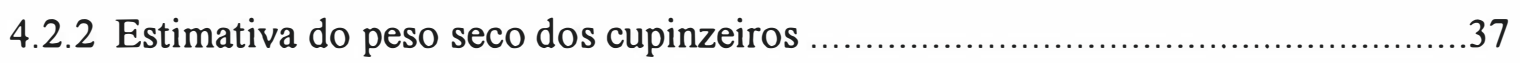

4.2.3 Estimativa da densidade dos cupinzeiros e densidade aparente do solo ...............38

4.3 Composição fisica, mineralógica e química dos cupinzeiros e solos associados.....39

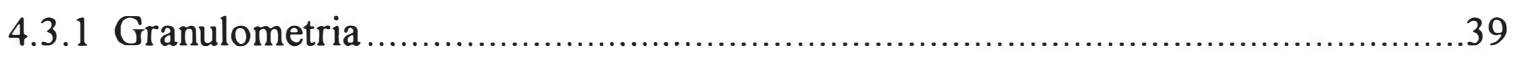

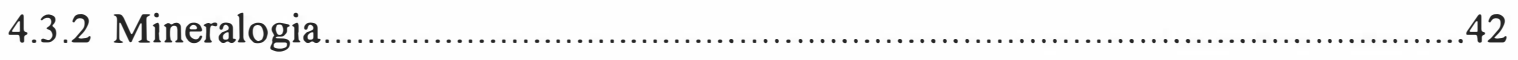

4.3.3 Composição química - $\mathrm{C}$ orgânico, $\mathrm{pH}, \mathrm{P}^{-\mathrm{PO}^{-3}}{ }^{-3}$ e cátions trocáveis .....................45

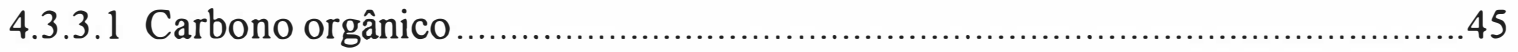

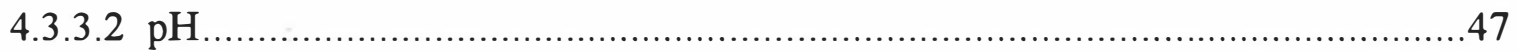

4.3.3.3 $\mathrm{P}_{-\mathrm{PO}_{4}}^{-3}$ (resina)

4.3.3.4 Bases trocáveis $\left(\mathrm{Ca}^{+2}, \mathrm{Mg}^{+2}, \mathrm{~K}^{+}, \mathrm{SB}^{1}, \mathrm{CTC}\right.$ calculada e V\%) .......................48

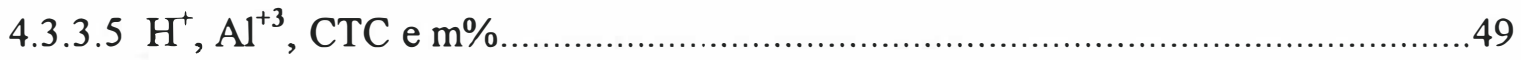

4.3.4 Composição química total: elementos maiores e traços ....................................54

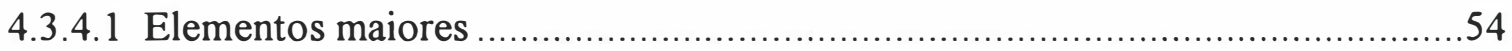

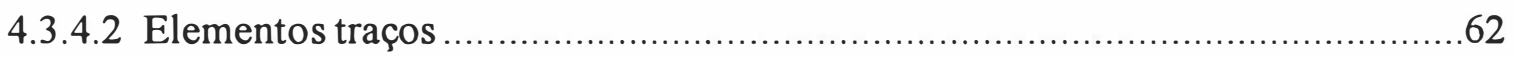


4.3.5 Estimativa dos teores dos principais constituintes mineralógicos do solo, a partir

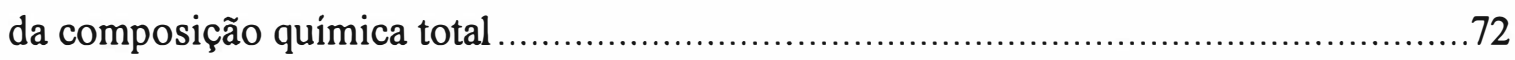

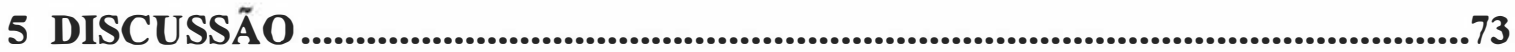

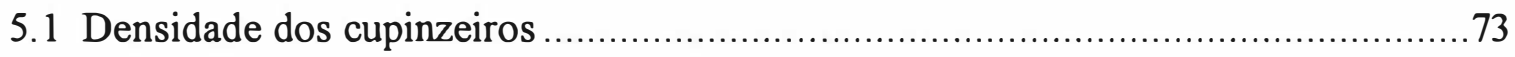

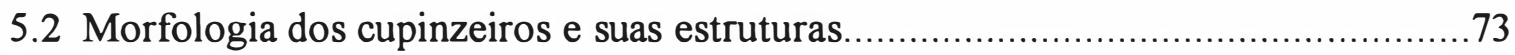

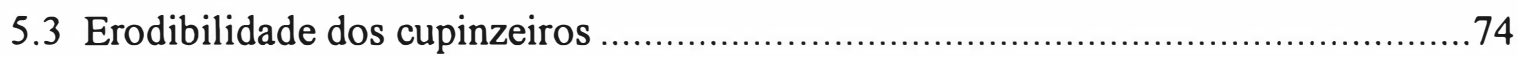

5.4 Evolução do perfil do solo e a atividade biológica .................................... 74

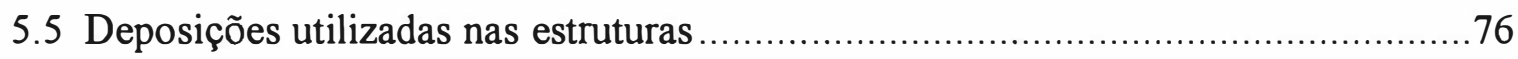

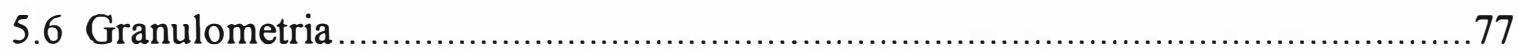

5.7 Argila dispersa em água e grau de floculação ................................................. 78

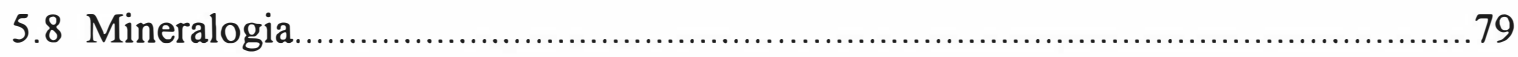

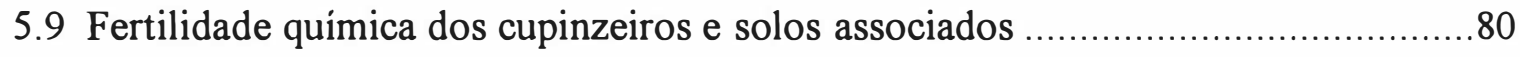

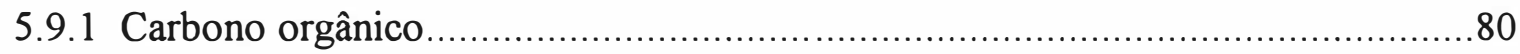

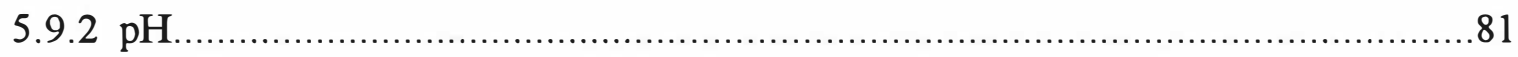

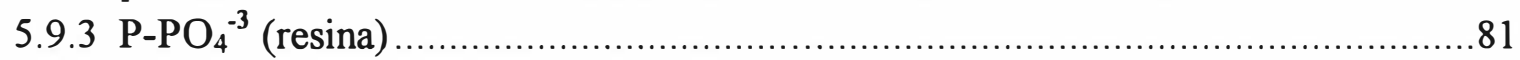

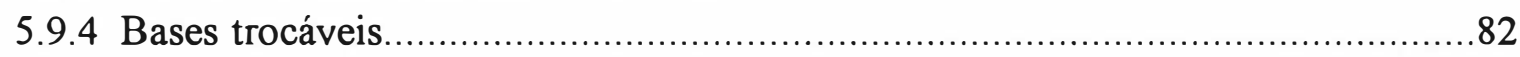

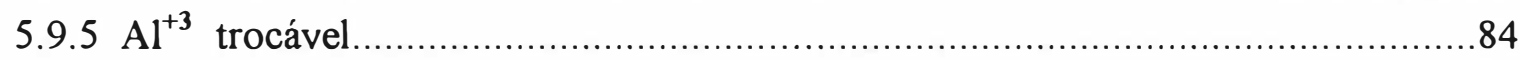

5.10 Ocorrência dos elementos maiores e traços nos cupinzeiros enos solos

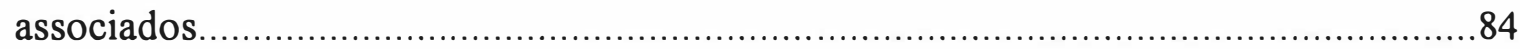

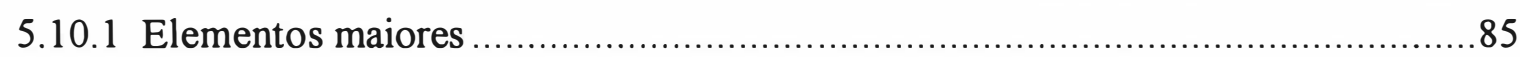

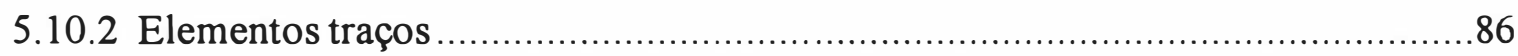

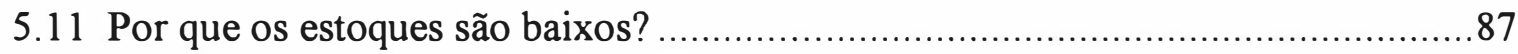

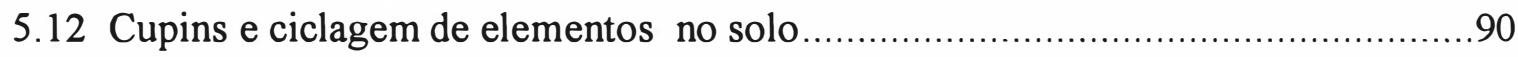

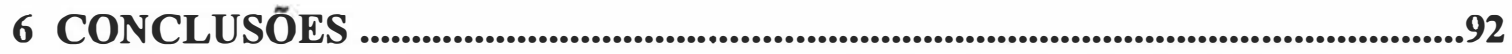

APÊNDICES........................................................................................................93

REFERÊNCIAS BIBLIOGRÁFICAS .............................................................116 


\title{
SOLOS E BIOCONSTRUÇÕES: MORFOLOGIA E GEOQUIMMICA DOS
}

\author{
CUPINZEIROS E DOS SOLOS ASSOCIADOS
}

\author{
NA REGIÃO DE HUMAITÁ (SUL DO ESTADO DO AMAZONAS)
}

\author{
Autor: MÁRCIA TOFFANI SIMĀO SOARES \\ Orientador: Prof. Dr. ADOLPHO JOSÉ MELFI
}

\section{RESUMO}

Nos ecossistemas tropicais, os cupins são considerados como um dos importantes grupos participantes dos ciclos biogeoquímicos. Eles afetam a dinâmica da matéria orgânica, assim como nas características morfológicas, físicas e químicas do solo.

Os objetivos deste estudo são: i) caracterizar cupinzeiros epígeos e solos adjacentes, ii) comparar os estoques de elementos imobilizados nos montículos e no solo.

A área de estudo localiza-se em uma savana herbácea, no sul do Estado do Amazonas. As amostras dos solos e dos cupinzeiros foram submetidas a análises químicas, fisicas, mineralógicas e morfológicas.

Os cupinzeiros apresentam maiores concentrações de $\mathrm{C}$ e nutrientes em relação ao solo adjacente. O mesmo é observado para os teores totais de $\mathrm{Mn}, \mathrm{Ca}, \mathrm{Ba}, \mathrm{Sr}$, $\mathrm{Br}$ e Au. Apesar das concentrações observadas, os estoques de elementos nos montículos são insignificantes quando comparados com o solo adjacente, ainda que a área apresente alta densidade $\left(608 \mathrm{ha}^{-1}\right)$. A pouca contribuição se deve a pequena superficie ocupada pelos montículos $(0,21 \%$ da área total). No entanto, a atividade construtora dos cupins é fundamental para a ciclagem de nutrientes e elementos no solo estudado. 


\title{
SOLS AND BIOCONSTRUCTIONS: MORPHOLOGY AND GEOCHEMISTRY OF TERMITE MOUNDS AND ASSOCIATED SOLS IN HUMAITÁ REGION (SOUTH OF THE AMAZONAS STATE, BRAZI)
}

\author{
Author: MÁRCIA TOFFANI SIMÃO SOARES \\ Adviser: Prof. Dr. ADOLPHO JOSÉ MELFI
}

SUMMARY

In tropical ecosystems, termites are considered as a significant soil fauna group which participate to biogeochemical cycles. They affect soil organic matter dynamics, as well as morphological, physical and chemical characteristics of soils.

The objectives of this study are i) to characterize epigeic termite mounds and adjacent soils, ii) to compare the stocks of elements (organic matter, nutrients, majors and trace elements) immobilized in mounds and soils.

The study area is located in an herbaceous savannah, south of Amazonas State. Chemical, physical, mineralogical and morphological analysis of mounds and soil were performed.

Mounds show higher concentrations of $\mathrm{C}$ and nutrients than the adjacent soils. The same is observed for total $\mathrm{Mn}, \mathrm{Ca}, \mathrm{Ba}, \mathrm{Sr}, \mathrm{Br}$ and $\mathrm{Au}$. But stocks of these elements within the mounds are insignificant when compared to the adjacent soils, although the area presents high mound density $\left(608 \mathrm{ha}^{-1}\right)$. This very low contribution results from the small surface occupied by the mounds $(0,21 \%$ of the total area). However, the building activity of termites is fundamental for nutrients and elements cycling in these soils. 


\section{INTRODUÇÃO}

O fluxo de elementos no solo é decorrente de complexos processos biogeoquímicos, que sofrem interferência da atividade de macro, meso $\mathrm{e}$ microrganismos. Estes seres são fundamentais na manutenção da fertilidade do solo, afetando a morfologia, as propriedades físicas e químicas, a dinâmica da matéria orgânica, a ciclagem de nutrientes e o crescimento das plantas (Wood, 1988).

O solo contém grande diversidade de espécies que apresentam complexas interações. Entre estes seres, os macroinvertebrados, representados principalmente por minhocas, cupins e formigas (Lavelle et al., 1994), participam intensamente dos processos envolvidos na evolução e manutenção dos solos.

Nos ecossistemas tropicais, os cupins (Insecta: Isoptera) são considerados por muitos autores como um dos mais importantes grupos participantes dos ciclos biogeoquímicos (Lee \& Wood; 1971, Wood \& Sands, 1978; Wood, 1988; GarnierSillam \& Harry, 1995). Intensos estudos realizados durante as duas últimas décadas têm indicado o papel desempenhado por cupins em diferentes habitats.

A fertilidade natural dos solos amazônicos é extremamente dependente da ciclagem de compostos orgânicos e minerais. Sendo a biota do solo a maior reguladora destes processos (Barros et al., 1996), e os cupins os maiores representantes da pedofauna no local de estudo, é de extrema importância a compreensão da atividade destes organismos, a contribuição destes para a ciclagem, estoque de elementos e a dinâmica atual do solo.

Este estudo tem por objetivo estimar e comparar os teores e os estoques de elementos químicos e minerais presentes no solo e nos cupinzeiros associados, através do: 
- Levantamento da população de cupinzeiros em área representativa dos campos nativos da região.

- Descrição morfologica dos cupinzeiros e dos solos, através de análises morfológicas em diferentes escalas, em amostras indeformadas de solo e de cupinzeiros.

- Determinação quantitativa (teores e estoques) dos elementos químicos e minerais presentes nos cupinzeiros e nos solos adjacentes.

Espera-se que a atividade dos cupins interfira na morfologia e na ciclagem de elementos no solo. Não se sabe qual a contribuição dos montículos para os estoques de elementos na área de estudo. 


\section{REVISÃO DE LITERATURA}

Os organismos do solo estão diretamente relacionados aos processos de ciclagem de nutrientes, conservação, construção e manutenção da estrutura do solo. Estes agem diretamente na intensa movimentação de partículas do solo, no ciclo de nutrientes e ativação da microbiota, contribuindo desta forma para a transformação dos nutrientes (Hole, 1981; Curry \& Good, 1992).

Pela ativação seletiva da microflora, em diferentes escalas de tempo e de espaço, os invertebrados regulam a mineralização e humificação da serrapilheira. Melhoram a estrutura física do solo aumentando a resistência de macroagregados por ingestão e egestão dos solos, misturando-os com resíduos orgânicos, cavando galerias e transportando terra para a superfície (Lavelle et al., 1988 e 1989). Ainda, são citados como os responsáveis por acelerar ou conter a erosão do solo (Hole, 1981).

A importância da fauna edáfica na dinâmica dos solos começou a se consolidar no final do século XIX (Lopes Assad, 1997). Dokuchaev em 1879, Darwin em 1881, e Drummond em 1887, já destacavam a importância de organismos vivos nos processos que ocorrem nos solos.

\subsection{Classificação dos organismos do solo}

De uma forma geral, os organismos que habitam o solo podem ser divididos entre a flora e a fauna. A flora compreende a macroflora (raízes de vegetais superiores) e microflora (bactérias e fungos). Os elementos da fauna podem ser classificados, em relação ao tamanho, em três categorias (Lavelle et al., 1994): 
- Microfauna: representada principalmente por nematóides e protozoários, com tamanho menor que $0,2 \mathrm{~mm}$, e biomassa média de $100 \mathrm{~g} \mathrm{~m}^{2}$ (Anderson, 1988);

- Mesofauna: representada por enquitreídeos, nematóides, ácaros, colêmbolas e larvas de diversos insetos. $O$ tamanho varia de 0,2 a $2,0 \mathrm{~mm}$ e a biomassa de 0,5 a $100 \mathrm{~g} \mathrm{~m}^{2}$ (adaptado de Lopes Assad, 1997);

- Macrofauna: tem como principais representantes os cupins, formigas e minhocas. O tamanho é superior a 2,0 mm, e a biomassa varia de 0,1 a $200 \mathrm{~g} \mathrm{~m}^{2}$ (adaptado de Lopes Assad, 1997). Estes organismos têm grande mobilidade no solo, constituindo a maior biomassa nos ecossistemas tropicais (Lal, 1987). Neste trabalho, os cupins terão maior destaque, pela grande incidência de suas construções e atividade na área estudada.

\subsection{Importância ecológica dos cupins}

Os cupins existem na Terra pelo menos desde 130 a 135 milhões de anos (Cretáceo Inferior) - (Martinez-Delclos \& Martinell, 1995). Atualmente são catalogadas 7 famílias e aproximadamente 2500 espécies de cupins por todo o mundo (Waller \& La Fage, 1987).

São encontrados entre as latitudes $45^{\circ}$ Norte e $45^{\circ}$ Sul (aproximadamente), com maior ocorrência na região intertropical. Dentro desta faixa, estão presentes em todos os tipos de solos. Vivem em comunidade, compreendendo várias centenas a milhões de indivíduos (Wood, 1988). Os cupinzeiros podem ser arbóreos, epígeos ou subterrâneos. De suas estruturas irradiam uma série de galerias para aquisição de alimentos, água e terra (Wood \& Sands, 1978, Grassé, 1984).

Os cupins podem contribuir de várias formas no funcionamento dos ecossistemas. Em relação aos processos pedológicos, seus hábitos detritivos e consumidores afetam as características químicas do solo, na decomposição de fragmentos de folhas e ciclagem de energia e nutrientes das plantas. Pelo seu hábito construtor, são considerados verdadeiros "engenheiros do solo", alterando suas características fisicas e morfológicas (Eschenbrenner, 1996). 


\subsection{Cupins, matéria orgânica e ciclagem de nutrientes}

Os cupins estão entre os mais importantes decompositores de matéria orgânica (Martius, 1994), podendo reciclar de 1/3 a mais de 1/2 dos detritos orgânicos de origem vegetal (Abe, 1980, citado por Bandeira, 1991). A construção de montes, ninhos e galerias, afeta as características físicas e químicas do material utilizado nestas estruturas. Suas partículas são selecionadas, transportadas, rearranjadas, unidas e misturadas com a matéria orgânica (Lee \& Wood, 1971). Garnier-Sillam \& Harry (1995), observaram que a matéria orgânica encontrada em partículas trabalhadas pelos cupins é mais polimerizada que o solo controle. As espécies que se alimentam de terra misturam material vegetal em decomposição com argila em seu intestino, contribuindo desta forma para a estabilização dos ácidos húmicos recém formados. As fezes enriquecidas com ácidos húmicos são utilizadas para a sustentação de câmaras e galerias. Segundo os autores supracitados, espécies que estabilizam a matéria orgânica são importantes na elaboração de complexos argilo-húmicos no solo, e portanto, contribuem para sua conservação e fertilidade. Uma vez a colônia de cupins morta, esta matéria orgânica torna-se disponível no solo.

\subsection{Relação entre propriedades químicas dos cupinzeiros e solos associados}

Vários estudos têm demonstrado uma tendência geral dos cupins em aumentar a concentração de matéria orgânica e nutrientes em suas estruturas (Wood, 1988; Peres Filho et al., 1990; Garnier-Sillam \& Harry, 1995; Lopes Assad \& Lacerda, 1995). As diferenças entre a composição química dos montículos e o solo ao redor podem variar de acordo com a espécie de cupim, a idade dos montículos, a parte amostrada destas estruturas e o tipo de solo (Nye, 1955).

Segundo Lavelle et al. (1994), as pelotas fecais dos cupins têm baixo conteúdo de elementos minerais, principalmente o nitrogênio. Todavia, sabe-se que o conteúdo intestinal dos cupins contém bactérias fixadoras de nitrogênio (SylvesterBradley et al.,1978; Prestwich \& Bentley, 1981). Basu et al. (1996) verificaram uma 
forte dependência da abundância e biomassa dos cupins na quantidade de matéria orgânica e nitrogênio no solo. Bruyn \& Conacher (1995) observaram significante alteração do pH no revestimento das galerias, associado a elevados teores de carbono. Os autores supracitados sugerem que, em solos de baixa fertilidade, os cupinzeiros podem funcionar como renovadores químicos do solo após sua morte, disponibilizando nutrientes às plantas, imobilizados pelos cupins.

\subsection{Porosidade e aeração do solo}

A atividade destes insetos também altera a porosidade do solo, através da construção de galerias. Nye (1955), estudando a atividade da espécie Macrotermes nigeriensis, observou que abaixo dos ninhos, a uma profundidade de 1 metro, o solo estava repleto de galerias com 0,63 a $1,23 \mathrm{~cm}$ de largura, apresentando manchas negras nas paredes. A maior concentração de galerias aparece entre 15 a 122 centímetros de profundidade. Mando et al. (1996), estudando o potencial dos cupins subterrâneos em evitar a degradação física de solos de regiões semi-áridas, observaram, em campos experimentais, que a porosidade e a infiltração da água são maiores que em solos que não sofreram atividade dos cupins.

\subsection{Individualização de partículas - a formação de pelotas}

Para identificar as alterações no solo provocadas pelos cupins, é importante conhecer os processos de individualização e transporte das partículas. Estes estão bem elucidados em revisão realizada por Eschenbrenner (1996).

Para escavar o solo, construir seus ninhos e transportar materiais, os cupins utilizam suas mandíbulas e o interior da cavidade bucal. As mandíbulas, fortemente quinitizadas, são capazes de dilacerar madeira e partículas do solo. $\mathrm{O}$ hypofarynix, móvel e eréctil órgão da cavidade bucal, é usado para moldar as pelotas dentro do cibarium (parte superior da cavidade bucal). 
O tamanho das partículas ingeridas e subsequente regurgitação ou excreção é controlado pela geometria do cibarium (regurgitação) ou pela geometria do intestino (excreção). As partículas carregadas desta forma estão na fração argila, silte e algumas areias menores que $0,5 \mathrm{~mm}$. A regurgitação é praticada pela maioria das espécies, ao passo que a passagem de solo pelo intestino parece ser limitada aos cupins que se alimentam de húmus.

Dentro do cibarium, partículas finas do solo são misturadas à saliva, moldadas com o hypofarynx e regurgitadas como uma pelota oval ou cilíndrica, 0,2 a 2,0 mm de diâmetro e 0,2 a $3.0 \mathrm{~mm}$ de largura. É a unidade elementar de construção. De acordo com a espécie e a localização na construção, estas pelotas são usadas com ou sem adição de partículas arenosas carregadas nas mandíbulas, com ou sem adição de excrementos, com ou sem adição de solo excretado.

\subsection{Alterações texturais e diferenciação de material}

Os cupins podem alterar a textura do solo através da remoção de partículas finas dos horizontes mais profundos para a superficie, onde são usadas para a construção de montículos e caminhos superficiais (Lee \& Wood, 1971, Wood, 1988), ou são acumuladas em galerias de alimentação em árvores vivas, toras, cepas e estruturas de madeira (Lee \& Wood, 1971). Pinheiro et al. (1993) observaram que os cupins, ao edificarem o cupinzeiro, promovem mistura de partículas das camadas subjacentes às de superficie. Em revisão de Wood (1988), o autor encontrou algumas estimativas para a taxa de acumulação anual de partículas pelos cupins: 0,02 a 1,00 $\mathrm{mm}$ no norte da Austrália, 0,025 $\mathrm{mm}$ na floresta nigeriana e $0,13 \mathrm{~mm}$ em Uganda.

Gamier-Sillam \& Harry (1995), estudando a estabilidade de cupinzeiros na floresta tropical úmida no Congo, observaram que ninhos da espécie Cubitermes fungifaber e Noditermes lamaniamus apresentam uma relação argila/areia diferente do horizonte superior do solo. Estas espécies incorporam mais argila que areia em suas estruturas. Bruyn \& Conacher (1995), estudando cupinzeiros na região semi-árida do oeste da Austrália, observaram que a textura dos cupinzeiros e das galerias possuíam 
grande quantidade de partículas de argila, quando comparada com o solo controle. Em seus estudos, aproximadamente 1/3 do montículo é derivado de argilas do subsolo (30$45 \mathrm{~cm}$ ), e o restante da camada $0-30 \mathrm{~cm}$ do solo.

\subsection{Contribuição ao empobrecimento em argila do horizonte superficial do solo}

Perda de argila dos horizontes superiores dos solos tropicais é um fenômeno comum. De acordo com Eschenbrenner (1986), a perda de plasma pode ser resultante da erosão seletiva superficial de material carregado pela pedofauna, com forte contribuição dos cupins.

A perda do plasma resulta do efeito cumulativo de uma sucessão de quatro processos: 1) cupins e outros organismos retiram partículas do solo e as conduzem aos montículos. 2) A energia cinética das gotas de chuva destas construções levam a dissociação do plasma com os grãos de esqueleto, o plasma fica em suspensão na água. 3) De acordo com a permeabilidade, a intensidade da chuva e o gradiente de declividade, o plasma em suspensão movimenta-se verticalmente no solo (infiltração), ou na superfície do solo (erosão seletiva). Os grãos que constituem o esqueleto do solo se movimentam pouco ou ficam estáticos, mantendo-se na superficie. 4) Os minerais que constituem o esqueleto são então progressivamente incorporados ao horizonte superficial (Eschenbrenner, 1986).

\subsection{Alterações morfológicas dos cupinzeiros e do solo}

Análises morfológicas são utilizadas na caracterização de cupinzeiros e ajudam a compreender a forma de construção de várias famílias e gêneros de cupins (Lee \& Wood, 1971). A análise micromorfológica de cupinzeiros serve para reconhecer o efeito e quantificar a atividade da fauna nos solos (Mermut et al., 1984).

O efeito da atividade de cupins na morfologia e na formação de solos está detalhado na revisão feita por Eschenbrenner (1996). A pedoplasmação (Flach et al., 1968) resulta diretamente da atividade dos cupins (e provavelmente de outros animais do 
solo - como as formigas) e não da evolução in situ do saprólito. Este processo implica dupla transferência de materiais do solo: exportação no momento da escavação e importação no momento do preenchimento das galerias. Portanto, como o material é reunido na forma de grânulos termíticos coalescentes, o processo de pedoplasmação assemelha-se a microagregação (Eschenbrenner, 1996).

Para verificar a ocorrência das transformações ocasionadas por cupins, é importante a realização de análises morfológicas, observando-se a organização dos constituintes do solo e dos cupinzeiros associados, da escala macromorfológica à micromorfológica. 


\section{MATERIAL E MÉTODOS}

\subsection{Características da área de estudo}

\section{Localização}

A área de estudo localiza-se na parte ocidental da Amazônia, fronteira sul

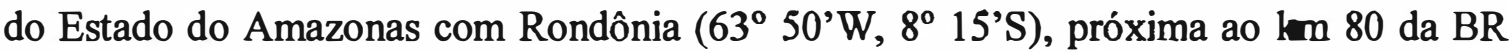
319 (Figura 1). A área experimental tem 16 hectares. No local está sendo desenvolvido o Projeto Temático da FAPESP (processo 96/1447-1), intitulado "Organização e Funcionamento Hidrobiogeoquímico das Coberturas Lateríticas da Amazônia", sob coordenação do Prof. Dr. Adolpho José Melfi.
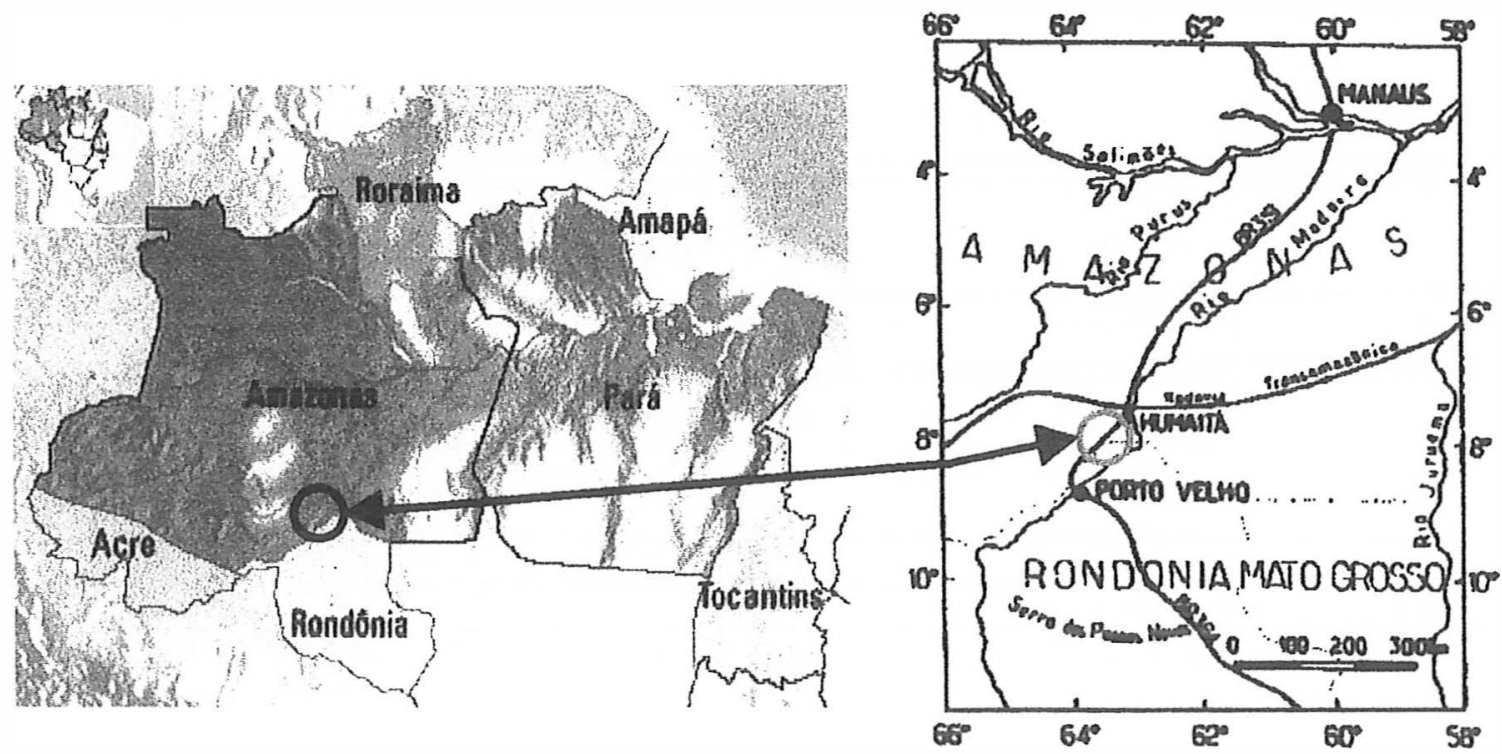

Figura 1 - Localização da área de estudo. 
Geologia

Afloram na região sedimentos siltosos e argilosos da Formação Solimões (TQs) de idade pleistocênica. Os solos desenvolvidos a partir desses sedimentos são classificados como Podzólicos Vermelho-Amarelos álicos plínticos e Lateritas Hidromórficas de elevação (Amaral Filho et al., 1978).

Clima

O clima da região é classificado como Amwi: quente e úmido, com curta estação seca, sem grande variação sazonal (Amaral Filho et al., 1978). A precipitação média anual é de 2353 mm (BRASIL, 1992).

Vegetação

A vegetação é classificada como área de tensão ecológica savana/floresta (Amaral Filho et al., 1978). A área experimental está inserida em um campo nativo ("Campos de Humaitá") - (Figura 20). Neste local predominam as espécies herbáceas geófitas ciperáceas, gramíneas, xiridáceas e epífitas orchidáceas, que indicam ambiente encharcado com impedimento de drenagem (Doi et al., 1978).

Macrofauna do solo

A área possui atividade intensa de macroorganismos do solo, em especial cupins dos gêneros Armitermes (dominante) e Conitermes, formigas dos gêneros Acromyrmex e Atta, e minhocas do gênero Megascolex. A ação destes organismos no solo pode ser observada pelos montículos e coprólitos presentes na superficie e pelas alterações provocadas no perfil do solo. 


\subsection{Inventário e medidas dos cupinzeiros}

O inventário dos cupinzeiros evidenciou a predominância de uma espécie da sub-família Nasutitermitinae, gênero Armitermes, na área de savana (Figuras 20 e 21), onde, em uma superficie homogênea, escolheu-se a unidade de estudo. Numa área de $50 \times 50 \mathrm{~m}$, cada cupinzeiro da espécie dominante, de forma cônica, foi numerado, localizado em relação à quadrícula de referência $(x, y)$ e submetido à determinação da altura e do perímetro máximo.

\subsection{Escolha dos cupinzeiros para determinação das características morfológicas, fisicas, químicas e mineralógicas}

Os cupinzeiros referenciados e medidos foram divididos em três diferentes categorias. Estas divisões foram realizadas a partir da curva de freqüência das alturas observadas. Os cupinzeiros de alturas inferiores ao primeiro quartil $\left(Q_{1}\right)$ foram classificados como pequenos (P). Da mesma forma, os cupinzeiros de alturas superiores ao terceiro quartil $\left(\mathrm{Q}_{3}\right)$ foram classificados como grandes $(\mathrm{G})$. A classe intermediária (I) foi definida a partir da altura correspondente a moda.

\subsection{Estabelecimento da relação altura x peso seco}

Esta relação possibilita a estimativa do peso seco de todos os cupinzeiros demarcados. Para a escolha representativa das estruturas para pesagem, foram estabelecidas classes amostrais, a partir da divisão da amplitude total da altura (altura máxima - altura mínima) em 20 intervalos iguais. Para cada classe foi escolhido, fora da área mapeada (a fím de não alterar a área de amostragem), cupinzeiros para determinação do peso e do teor de umidade. O montículo foi coletado e pesado no próprio local. 


\subsection{Amostragem dos cupinzeiros}

\subsection{Coleta de amostras homogeneizadas dos cupinzeiros}

Estas amostras representam a totalidade do cupinzeiro e foram realizadas na seguinte seqüência: a) corte vertical-axial do cupinzeiro e escavação da trincheira até $70 \mathrm{~cm}$ de profundidade (Figura 2a); b) recuperação da totalidade da metade "b" sob uma lona plástica (Figura $2 b$ ); c) rompimento do material em pedaços menores que $2 \mathrm{~cm}$; d) homogeneização do material; e) quartear, até obter-se uma amostra de aproximadamente $1 \mathrm{~kg}$, representativa do cupinzeiro inteiro.
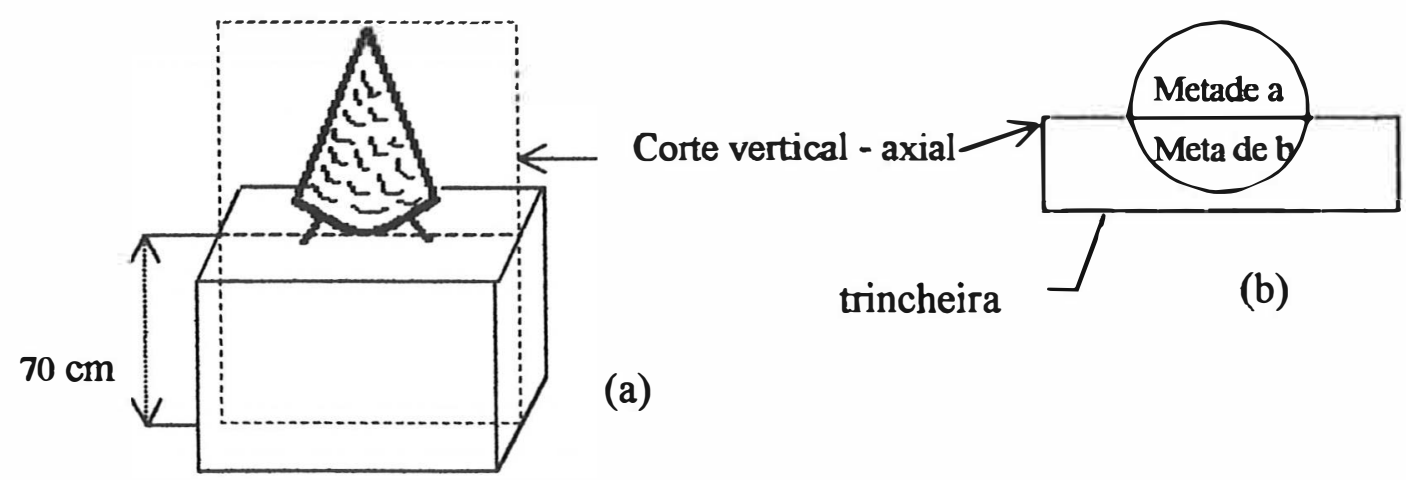

(a)

Figura 2 - (a) Vista geral com localização do corte vertical - axial de um cupinzeiro; (b) plano com localização do corte vertical - axial de um cupinzeiro e da trincheira.

3.5.2 Coleta de amostras das estruturas isoladas dos cupinzeiros e das camadas do solo contíguo a estes

Para a realização destas amostragens, o trabalho de campo ocorreu na seguinte seqüência: a) Descrição da macromorfologia do cupinzeiro e do solo, a partir da metade "a" não tombada e da parede vertical da trincheira; b) amostragem do cupinzeiro e do solo, segundo a Figura 3. 


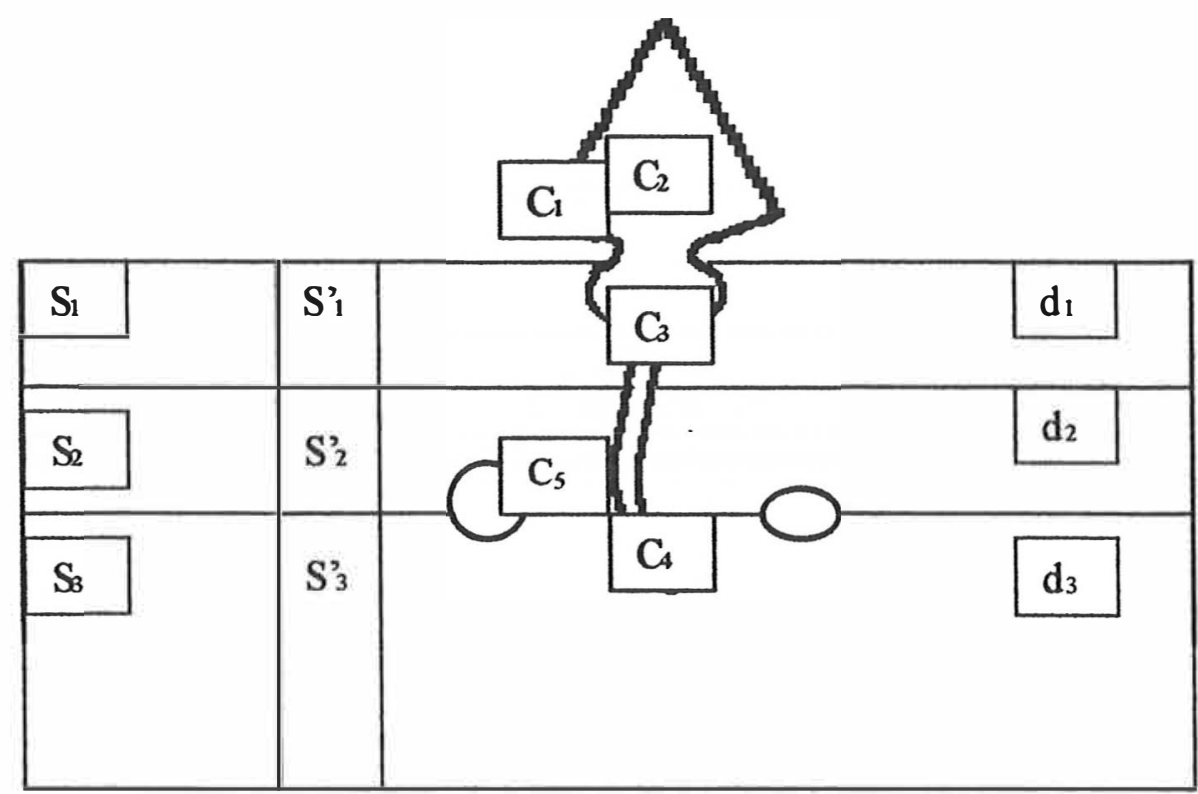

\section{Legenda:}

$\mathrm{S}$ e $\mathrm{C}$ - Amostras indeformadas para meso e micromorfolgia S'- Amostras para análises químicas, fisicas e mineralógicas d-Amostras indeformadas (anéis volumétricos) para densidade aparente. Locais definidos:

$\mathrm{S}_{1}, \mathrm{~S}_{1}{ }_{1}$ e d $\mathrm{d}_{1}$ : camada 0-15 cm

$\mathrm{C}_{1}$ : muralha externa

$\mathrm{S}_{2}, \mathrm{~S}_{2}{ }_{2}$ e d $\mathrm{d}_{2}$ : camada $15-30 \mathrm{~cm}$

$\mathrm{C}_{2}$ : zona intermediária epígea

$\mathrm{S}_{3}, \mathrm{~S}_{3}{ }_{3}$ e d $\mathrm{d}_{3}$ : camada $30-50 \mathrm{~cm}$

$\mathrm{C}_{3}$ : zona intermediária hipógea

$\mathrm{C}_{4}$ : galeria hipógea

$\mathrm{C}_{5}$ : câmara hipógea

Figura 3 - Corte vertical-axial de um cupinzeiro e do solo, e localização das amostras. 


\subsection{Diferenciação Macromorfológica Vertical Detalhada do Solo}

Amostras indeformadas representativas do perfil foram retiradas de uma trincheira, fora da zona de atividade do cupinzeiro, e a cada 5 centímetros de profundidade. A seguir, foram armazenadas no pedocomparador a fim de realizar a descrição morfológica no laboratório. Também foram retiradas amostras indeformadas para análises meso e micromorfológicas. A coleta foi realizada da base para o topo da trincheira. Os monólitos foram submetidos a análise descritiva, de acordo com Lemos \& Santos (1982), adaptado. Observou-se cor, textura, estrutura (tipo, tamanho, grau estruturação), cerosidade, manchas e concreções (cor, dimensões, quantidade, localização, limite, contraste, grau endurecimento), raízes (dimensões, orientação, abundância) e poros (tipo, dimensões, abundância, predominância).

\subsection{Análises físicas, mineralógicas e químicas}

\subsubsection{Análises fisicas (Figura 22)}

Foram realizadas no Laboratório de Física e Mineralogia do Solo do Departamento de Solos e Nutrição de Plantas, ESALQ/USP. As determinações foram as seguintes:

- Granulometria e umidade: as frações areia muito fina, areia fina, areia média, areia grossa e areia muito grossa foram determinadas por peneiramento. Para os teores de silte e argila, utilizou-se dispersante, pelo método de Bouyoucos (EMBRAPA, 1997). O teor de umidade foi determinado segundo Kiehl (1979).

- Densidade aparente: a densidade aparente foi determinada pelo método do cilindro volumétrico, com capacidade para $100 \mathrm{~cm}^{3}$ de terra. 


\subsubsection{Mineralogia}

Amostras representativas do solo, coletadas em diferentes profundidade, $\mathrm{e}$ dos cupinzeiros, foram submetidas à destruição da matéria orgânica por $\mathrm{H}_{2} \mathrm{O}_{2} 30 \%$ à quente. A seguir, foram lavadas com acetado de sódio $1 \mathrm{~N}$ a pH 5,0 para remoção dos cátions liberados.

A fração areia total e silte grosso foram separadas por peneiramento (peneiras de 50 e $20 \mu \mathrm{m}$, respectivamente). Para a separação da fração argila $(<2 \mu \mathrm{m})$, utilizou-se o hexametafosfato de sódio como dispersante e decantação por 8 horas em tubo de proveta com suporte para 1 litro e remoção por sifonamento. A fração silte fino (20 a $2 \mu \mathrm{m}$ ), restante no tubo, foi centrifugada por 3 minutos a $700 \mathrm{rpm}$, por diversas vezes, para depuração da amostra.

Uma parte da fração argila foi separada para preparação de lâminas; outra parte foi submetida a remoção de óxidos de ferro por adição de ditionito de sódio, para possibilitar a concentração de silicatos e favorecer a orientação preferencial dos colóides do solo. Esta orientação é útil na intensificação dos feixes difratados dos espaçamentos basais, que caracterizam os diferentes tipos de argilominerais.

As amostras de argila deferrificada foram saturadas com $\mathrm{KCl}$ e $\mathrm{MgCl}_{2}$, a fim de identificar os minerais expansíveis. As amostras saturadas com $\mathrm{K}$ foram transferidas com espátula para a lâmina e orientadas. Após secas, foram aquecidas a $350^{\circ} \mathrm{C}$ por 2 horas, a fim de decompor os óxihidróxidos de $\mathrm{Fe}$ e $\mathrm{Al}$, transformando-os em óxidos. Após analisadas por difração de raios - $\mathrm{X}$, as mesmas lâminas foram aquecidas a $550^{\circ} \mathrm{C}$, para a destruição da caulinita e novamente analisadas.

As amostras saturadas com $\mathrm{Mg}$ foram transferidas para lâminas, orientadas, saturadas com etileno glicol a $10 \%$ e analisadas. As frações siltes foram submetidas a análise em amostras não orientadas (método do pó).

O equipamento utilizado foi um difratômetro Phillips PW 3710 Based com tubo de cobre (radiação $\mathrm{K} \alpha$ de 0,154060 a 0,154439 nm) e filtro de níquel. Para as frações silte grosso e silte fino, as amostras foram irradiadas a maior velocidade $\left(1,72^{\circ}\right.$ $\left.2 \theta \mathrm{min}^{-1}\right)$, para análise exploratória do material; argila sem tratamento, argila saturada 
com $\mathrm{K}$ e aquecida a $350^{\circ} \mathrm{C}$, argila saturada com $\mathrm{Mg}$ e argila saturada com $\mathrm{K}$ e aquecida a $550^{\circ} \mathrm{C}$, a $1^{\circ} 2 \theta \mathrm{min}^{-1}$, velocidade que propicia análise mais acurada das amostras.

A identificação dos minerais foi realizada pela observação dos espaçamentos basais (Jackson, 1969). Os principais espaçamentos estão compilados na Tabela 1.

Tabela 1 - Principais espaçamentos iterplanares utilizados na identificação dos minerais.

\begin{tabular}{|c|c|c|c|c|}
\hline \multirow[t]{2}{*}{ Mineral } & \multicolumn{4}{|c|}{ Tratamento } \\
\hline & Seca ao ar & Etileno glicol & $K-350^{\circ} \mathrm{C}$ & $K-550^{\circ} \mathrm{C}$ \\
\hline $\begin{array}{l}\text { Caulinita }(\AA) \\
\left({ }^{\circ} 2 \theta \mathrm{CuK} \alpha\right)\end{array}$ & $\begin{array}{lrr}7,15 & 1,49 & 3,58 \\
(12,3 & 62,32 & 24,87)\end{array}$ & $\begin{array}{c}7,15 \\
(12,3)\end{array}$ & $\begin{array}{c}7,15 \\
(12,3)\end{array}$ & - \\
\hline $\begin{array}{l}\text { Vermiculita }(\AA) \\
\left({ }^{\circ} 2 \theta \mathrm{CuK} \alpha\right)\end{array}$ & $\begin{array}{lrr}14 & 12,5 & 4,5 \\
(5,89 & 7,0 & 19,7)\end{array}$ & $\begin{array}{c}14 \\
(5,89)\end{array}$ & $\begin{array}{c}10,0 \\
(8,84)\end{array}$ & $\begin{array}{l}10,0 \\
(8,84)\end{array}$ \\
\hline $\begin{array}{l}\text { Muscovita 3T }(\AA) \\
\left({ }^{\circ} 2 \theta \mathrm{CuK} \alpha\right)\end{array}$ & $\begin{array}{rrr}9,97 & 3,33 & 4,99 \\
(8,87 & 26,77 & 17,77)\end{array}$ & $\begin{array}{r}10,0 \\
(8,84)\end{array}$ & $\begin{array}{r}10,0 \\
(8,84)\end{array}$ & $\begin{array}{c}10,0 \\
(8,84)\end{array}$ \\
\hline $\begin{array}{c}\text { Mica - vermiculita }(\AA) \\
\left({ }^{\circ} 2 \theta \mathrm{CuK} \alpha\right)\end{array}$ & $\begin{array}{c}22-24 \\
(4,02-3,68)\end{array}$ & $\begin{array}{c}22-24 \\
(4,02-3,68)\end{array}$ & $\begin{array}{c}22-24 \\
(4,02-3,68)\end{array}$ & $\begin{array}{l}10,00 \\
(8,84)\end{array}$ \\
\hline $\begin{array}{l}\text { Quartzo }(\AA) \\
\left({ }^{\circ} 2 \theta \operatorname{CuK} \alpha\right)\end{array}$ & $\begin{array}{ccc}3,34 & 4,26 & 1,82 \\
(26,69 & 20,85 & 50,12)\end{array}$ & & & \\
\hline
\end{tabular}

\subsubsection{Análises químicas}

As análises químicas para fins de fertilidade foram realizadas pelo Laboratório de Química do Solo do Departamento de Solos e Nutrição de Plantas, ESALQ/USP. O carbono total foi analisado no Laboratório de Biogeoquímica do Solo, no Centro de Energia Nuclear na Agricultura (CENA/USP), e os elementos maiores e menores foram analisados no "Activation Laboratories Ltd.", Canadá. As seguintes análises foram realizadas:

- $\mathrm{pH}$ : determinação pelo potenciômetro, relação solo: líquido (água, $\mathrm{CaCl}_{2} \mathrm{e} \mathrm{KCl}$ ) 1:2,5 (Raij \& Quaggio, 1983);

- Carbono orgânico: determinado com um analisador LECO CR - 412;

- Cátions trocáveis (Raij \& Quaggio, 1983; Vitti, 1988; EMBRAPA, 1997): $\mathrm{Ca}^{2+} \mathrm{e}$ $\mathrm{Mg}^{2+}$ trocáveis, através da extração com resina trocadora de íons, e determinação por 
espectrofotometria de absorção atômica; $\mathrm{K}^{+}$e $\mathrm{Na}^{+}$trocáveis, através da extração com resina trocadora de íons e determinação por fotometria de emissão de chama; $\mathrm{Al}^{3+}$ trocável, através da extração com $\mathrm{KCl} 1 \mathrm{~N}$, e determinação por volumetria de neutralização;

- CTC efetiva, CTC potencial, V\%, m\%, $\Delta \mathrm{pH}$ : parâmetros obtidos a partir dos resultados analíticos ${ }^{1}$.

- $\mathrm{H}^{+}+\mathrm{Al}^{3+}$ trocável: determinado através da extração pelo $\mathrm{KCl} 1 \mathrm{~N}$, e determinação volumétrica com solução diluída de $\mathrm{NaOH}$ (EMBRAPA, 1997);

- $\mathrm{PO}_{4}^{-3}$ : método da resina trocadora de ânions, e determinação por espectrofotômetro com transmissão máxima a $720 \mathrm{~nm}$ ou 885 nm (EMBRAPA, 1997);

- Composição química total (Elementos Maiores e Menores): determinado por espectrometria de plasma acoplado (ICP), espectroscopia de massa e fluorescência de raio $\mathrm{X}$.

\subsubsection{Microscopia Eletrônica de Varredura (MEV) e Microanálise}

Amostras de paredes de câmaras de cupinzeiros foram recobertas com carbono, a fim de se identificar, por microanálise, os elementos presentes nas estruturas analisadas. Amostras da fração areia da camada $30-50 \mathrm{~cm}$ do solo foram recobertas com ouro, para melhor nitidez das imagens. Para o recobrimento com carbono e ouro foi utilizado o Evaporador Danton Vacuum Desk II. As observaç̃̃es e microanálises foram realizadas no MEV - JEOL KGM 5600LV, acoplado ao EDS Noran, com detector de fluoreto de lítio. Todo o procedimento foi executado no NUPEGEL/USP.

\footnotetext{
${ }^{1} \mathrm{CTC}=$ capacidade de troca catiônica; V\% = saturaço por bases $\left(\mathrm{Ca}^{2}+\mathrm{Mg}^{2+}+\mathrm{K}^{+} \times 100\right)$; $\mathrm{m} \%=$ saturação por alumínio $\left(\frac{\mathrm{Al}}{\mathrm{Ca}^{2+}+\mathrm{Mg}^{2+}+\mathrm{K}^{+}} \times 100\right)$. 


\subsection{Identificação dos cupins}

Em relação aos cupins, exemplares da família Termitidae, sub família Nasutitermitinae foram coletadas e conservadas em álcool, para a posterior classificação taxonômica em nível de gênero e espécie, no Museu de Zoologia USP/SP.

\subsection{Forma de análise dos resultados}

Para a determinação do peso seco de todos os cupinzeiros demarcados na área, foi realizada curva de regressão da relação peso seco $x$ morfologia. A curva possibilita, a partir dos dados analíticos, determinar o conteúdo de elementos químicos e minerais imobilizados pelos cupins.

Para a escolha dos cupinzeiros a serem amostrados para análise química, física, mineral e morfologicamente, as estruturas inicialmente mensuradas foram divididas em três categorias por classes de tamanho: pequenas (" $\mathrm{P}$ "), intermediárias ("T") e grandes (“G”). Os resultados químicos e físicos foram submetidas a análise de variância dos dados, considerando a variável classificatória "tamanho". Em seqüência, foi realizado o teste de comparação de médias, em três etapas: 1) considerando a totalidade dos cupinzeiros e do solo (4 tratamentos com 9 repetições cada); 2) dividindo os cupinzeiros e os solos em diferentes classes de cupinzeiros $(3 \times 4$ tratamentos com 3 repetições cada); 3) comparando as diferentes classes de cupinzeiros (3 tratamentos com 3 repetições cada). As análises comparativas possibilitaram avaliar a contribuição dos elementos químicos contidos nos solos para as estruturas, a interferência da atividade dos cupins da espécie estudada no solo da região e possíveis diferenças entre os conteúdos de elementos químicos nos diferentes estágios de crescimento dos cupinzeiros.

A partir dos dados mineralógicos, foi possível apenas a análise descritiva, comparando a composição mineralógica das diferentes estruturas dos cupinzeiros com o solo. Para as análises macro, meso e micromorfológicas, também foi efetuada apenas a análise descritiva das diferentes estruturas dos cupinzeiros e dos diferentes horizontes do solo. 


\section{RESULTADOS}

\subsection{Morfologia dos cupinzeiros e dos solos associados}

\subsubsection{Descrição Morfológica do Solo (Apêndice 2)}

O solo em estudo foi classificado, de acordo com o mapeamento do Projeto RADAMBRASIL (Amaral Filho et al., 1978) como Laterita Hidromórfica de Elevação, e pela classificação brasileira atual (EMBRAPA, 1999) como Plintossolo.

$\mathrm{O}$ perfil do solo pode ser dividido em três principais horizontes: $\mathrm{O}$ horizonte superficial $(0-14 / 18 \mathrm{~cm})$ é caracterizado pela cor escura, agregados granulares, maior acúmulo de matéria orgânica e intensa atividade biológica. $\mathrm{O}$ horizonte pseudo glei $(14 / 18-30 / 40 \mathrm{~cm})$, é caracterizado pela mudança progressiva de cor, com matizes brunas, amareladas e acinzentadas, e estruturação prismática, com formação de fissuras (Figuras 23 e 24$)$. O horizonte plíntico $\left(30 / 40-70^{+} \mathrm{cm}\right)$ possui matriz acinzentada, com mosqueados vermelhos, e estrutura maciça (ver Anexos).

O lençol freático oscila de 6 metros de profundidade à superficie, em períodos de chuvas intensas. 


\subsubsection{Diferenciação Macromorfológica Vertical Detalhada}

A descrição está subdividida nos seguintes ítens: cor, textura, estrutura, consistência, feições pedológicas, porosidade e raízes.

\section{a. Cor da matriz do solo e dos volumes}

\section{Matriz}

Nos primeiros 3 - $8 \mathrm{~cm}$ prevalecem o cinza escuro - cinza $(2,5$ Y 4,5/1, seco) e preto (2,5 Y 2,5/1, úmido), devido o maior acúmulo de matéria orgânica. De 3/8 a 14/18 cm, ainda existe interferência da matéria orgânica na cor do solo, porém em menor intensidade, com o aumento da profundidade. A cor varia neste horizonte de cinza claro a bruno (10 YR a 2,5 Y 5,5/2, seco) e bruno acinzentado escuro - bruno muito escuro acinzentado (10 YR a 2,5 Y 3,5/2, úmido).

A partir dos 14/18 cm a interferência da matéria orgânica tem menor importância à cor, predominando os tons mais claros. $\mathrm{O}$ bruno claro e o cinza prevalecem com o aumento da profundidade. Até $25 \mathrm{~cm}$ observa-se cinza claro a bruno ( 10 YR a 2,5 Y 5,5/2, seco) e bruno acinzentado escuro - bruno muito escuro acinzentado (10 YR a 2,5 Y 3,5/2, úmido). A $25 \mathrm{~cm}$, o fundo matricial seco torna-se branco - cinza claro - bruno muito claro (10 YR 7,5/1,5) a amarelo claro (2,5 Y 7,5/2), e bruno amarelado claro - bruno amarelado - bruno oliváceo claro (10 YR a 2,5 YR 5,5/4 úmido).

A partir de $50 \mathrm{~cm}$ predominam o branco - cinza claro $(2,5$ Y 7,5/1 seco) e cinza (10YR a 2,5 Y5,5/1 úmido), evidenciando o processo de gleização.

\section{Manchas}

- Alaranjadas

Possuem pouca expressão nos primeiros $5 \mathrm{~cm}$. Apresentam matiz $5 \mathrm{YR}$ 5,5/8 seco e úmido, com diâmetro menor que $1 \mathrm{~mm}$ (difícil observação a olho nú), abundância de 3 a 5\%, localizadas principalmente nos poros tubulares, formados por raízes (região de oxidação do ferro). Observam-se poucas manchas onde não há poros. $\mathrm{O}$ 
limite entre as manchas e a matriz é abrupto, com pouco contraste.

A cor vermelha intensifica-se com o aumento da profundidade, tendendo a matizes vermelho amarelado (5YR 5/8 seco e úmido) a vermelho (2,5YR 6/8 a 5/8, seco, e 2,5YR 4,5/8 úmido), à $25-30 \mathrm{~cm}$. São difusas, com diâmetro $3-4 \mathrm{~mm}$, formadas principalmente nos poros tubulares de radicelas, limite abrupto, contraste difuso.

- Vermelhas

O contraste com o solo passa a ser proeminente a $30 \mathrm{~cm}$, com manchas vermelhas (2,5 YR 5/8 a 4/8 quando seco, e 2,5 YR 5/8 úmido) a alaranjadas (5 YR 5/8, seco e úmido). O limite pode ser difuso ou distinto, a maioria concentrada no fundo matricial, com $10 \%$ de ocorrência. Com a profundidade o contraste das manchas com o solo aumenta, com maior intensidade da cor vermelha e maior tamanho das manchas.

A partir de $40 \mathrm{~cm}$ observam-se manchas maiores, porém de tamanho variável (1,5 cm ou menos). As cores são mais escuras (vermelho escuro 2,5 YR 4/8 seco; 2,5 YR 4/8 a 10 R 4/8 úmido), o contraste com a matriz do solo é forte e o limite é abrupto. Ocupam 15 a $20 \%$ da matriz do solo. Nesta profundidade, ocorrência ocasional de nódulos com $3 \mathrm{~mm}$ de diâmetro, vermelho escuro (10 $\mathrm{R} \mathrm{4/8}$ seco e úmido) é observada.

A partir de $50 \mathrm{~cm}$ prevalecem as manchas vermelhas mais escuras (10 R $4 / 8,3 / 6$ e 3/4, seco e úmido), com $30 \%$ de ocorrência, aumentando a $40 \%$ até $70 \mathrm{~cm}$. Apresentam tamanho variável $(0,6$ a $8 \mathrm{~cm}$ de diâmetro), angulares, limite claro a abrupto, contraste forte.

\section{- Cinzas}

Manchas relativas ao processo de hidromorfismo surgem a partir de 30 $\mathrm{cm}$. A cor varia de $5 Y$ 7/1 quando seco a $5 Y$ 6/1 quando úmido. $O$ limite com a matriz varia de difuso a abrupto. São porosas, de porosidade tubular. Apresentam diâmetro médio $0,5 \mathrm{~cm}$ e ocupam menos que $2 \%$ da matriz. As manchas aumentam com a profundidade, até ocuparem toda a matriz do solo.

Nesta mesma tonalidade ocorrem com freqüência pedotúbulos e 
granotúbulos de cupins e formigas, que estão descritos no item "pedotemas".

\section{b. Textura, Estrutura, Consistência e Cerosidade}

- Textura e Consistência

A textura do solo é argilo siltosa em todo o perfil. Todavia, a consistência passa de não plástico e não pegajoso, no horizonte $\mathrm{A}$, para ligeiramente plástico e ligeiramente pegajoso em subsuperfície, indicando leve incremento de argila em profundidade.

- Estrutura

De 0 a $10 \mathrm{~cm}$, a estrutura é granular bem desenvolvida, formada por agregados irregulares, de aproximadamente $1 \mathrm{~cm}$.

A partir de $10 \mathrm{~cm}$ a estrutura primária passa a ser prismática bem desenvolvida (Figuras 23 e 24) e a secundária, formada por agregados de tamanho médio a pequeno (média $1 \mathrm{~cm}$ de diâmetro), poliédrica subângulosa pouco desenvolvida.

A $30 \mathrm{~cm}$ a estrutura torna-se maciça e localmente poliédrica sub-angulosa a angulosa pouco desenvolvida, de $1,0 \times 2,5 \mathrm{~cm}$.

- Cerosidade

Ausente em todo o perfil.

c. Raizes

O sistema radicular tem maior densidade nos primeiros $5 \mathrm{~cm}$ do solo. As raízes possuem orientação vertical a oblíqua e diâmetro menor ou igual a $1,5 \mathrm{~mm}$.

$O$ volume reduz drasticamente a partir de $5 \mathrm{~cm}$, e as raízes concentram-se principalmente no interior de galerias e câmaras de origem biológica. $\mathrm{Na}$ ausência de bioporos, com o aumento da profundidade observa-se a diminuição do diâmetro das raízes, chegando a $0,5 \mathrm{~mm}$ ou menos à $55-60 \mathrm{~cm}$, e ocupando espaço de alguns poros tubulares. 


\section{d. Porosidade}

Nos primeiros $10 \mathrm{~cm}$, entre agregados formam-se poros de empilhamento complexo, com diâmetro médio $0,5 \mathrm{~mm}$, e poros intragregados, observáveis com o auxílio de lupa.

As fissuras começam a surgir, em média, a $3-10 \mathrm{~cm}$ da superficie (fim do horizonte $A_{1}$ ), tendo suas terminações a $33-57 \mathrm{~cm}$ (início horizonte $B$ plíntico). São $50 \%$ ortoplano, $50 \%$ metaplano. A conformação das fissuras é angulosa, angulosidade de $4 \mathrm{~cm}$. A grande maioria está ocupada por raízes. É comum a ocorrência de câmaras e galerias biológicas entre as fissuras.

Os poros tubulares ocorrem em todas as profundidades. Até $10 \mathrm{~cm}$, são menores que $0,5 \mathrm{~mm}$, com densidade 10 seções $\mathrm{cm}^{-2}$. Nos $25 \mathrm{~cm}$ seguintes, o tamanho médio dos poros tubulares e sua densidade aumentam para $1,5 \mathrm{~mm}$ e 18 seções $\mathrm{cm}^{-2}$, respectivamente. $\mathrm{O}$ diâmetro continua crescente até $65 \mathrm{~cm}$, onde têm diâmetro médio 2,0-3,0 mm. Estes são localizados no fundo matricial, e poucos são preenchidos por radicelas. A partir de $65 \mathrm{~cm}$ têm diâmetro médio de $1 \mathrm{~mm}$ ou menos e densidade 4 a 8 seções $\mathrm{cm}^{-2}$.

Os vazios de atividade biológica estão presentes em todo o perfil, atravessando as estruturas pré-existentes. São dos seguintes tipos:

- Galerias: as galerias dos cupins do gênero Armitermes têm orientação horizontal e sub-vertical, revestidas ou não por pelotas pretas. Têm diâmetro médio 4 a $7 \mathrm{~mm}$ e espessura do revestimento menor que $1,0 \mathrm{~mm}$. Foram observadas em todo o perfil, atingindo profundidade superior a 1 metro.

Galerias de outras espécies de cupins também foram encontradas nos diferentes perfis. Atribui-se às galerias sem revestimento nas paredes, de diâmetro 1,0 mm, a cupins de menor tamanho, de espécie não identificada. Essas galerias são encontradas, além de na matriz do solo, em material granuloso cinza que preenche algumas câmaras de Acromyrmex (ver ítem "Pedotemas"). 
- Câmaras: as construídas pela espécie em estudo são irregulares, elipsoidais, de orientação horizontal ou transversal, com ou sem revestimento. São conectadas às galerias.

As câmaras da espécie não identificada de cupins são regulares, elipsoidais, sem revestimento nas paredes, de largura variável $(1,5 \mathrm{~cm}$ a $4,5 \mathrm{~cm})$, altura constante $(0,5 \mathrm{~cm})$ e diâmetro médio $4,0 \mathrm{~cm}$.

Câmaras de formigas do gênero Acromyrmex são comuns em todo o perfil. São regulares, esferoidais a levemente elipsoidais, com diâmetro ao redor de 10 cm (Figuras 4 a 7 ).

e. Feições pedológicas (pedotúbulos de galeria e de câmara, revestimento de paredes e nódulos)

- Pedotúbulos de galeria e de câmara:

Isotúbulos de galerias, formados a partir da atividade de minhocas, são abundantes na camada $0-30 \mathrm{~cm}$. Possuem $0,5 \mathrm{~cm}$ a $1,0 \mathrm{~cm}$ de diâmetro e são constituídos por material mais escuro que a matriz (cinza muito escuro - 2,5 Y 3/1 seco; preto - 2,5 Y $2,5 / 1$ úmido); abundância $5 \%$ nos primeiros $15 \mathrm{~cm}$, reduzindo a $3-1 \%$ até $30 \mathrm{~cm}$.

Câmaras de formigas do gênero Acromyrmex foram encontradas em todas as profundidades. Algumas estavam preenchidas por material granular cinza, onde se encontrou atividade de cupins de espécie não identificada. Galerias da espécie estudada (gênero Armitermes) também foram encontradas em todo o perfil, alcançando profundidade superior a 1 metro.

- Revestimento de paredes: as paredes das fissuras são revestidas por cutã escuro ou de material preto depositado por cupins. Câmaras de formigas do gênero Acromyrmex possuem revestimento das paredes alaranjado, provavelmente pela oxidação local do ferro. 
- Nódulos: ocorrem a partir de $40 \mathrm{~cm}$, com $3 \mathrm{~mm}$ de diâmetro, sem cortex, consistência ligeiramente dura, macia, ligeiramente plástico, ligeiramente pegajoso. A consistência desses nódulos modifica-se com a profundidade para muito duro e firme.

- Microagregados das câmaras de Acromymmex: Em todo o perfil estão presentes microgrânulos de aproximadamente $1 \mathrm{~mm}$, localizados no interior de galerias, fissuras e, principalmente, de câmaras abandonadas de formigas do gênero Acromyrmex. São formados, provavelmente, pela atividades de cupins de espécie não identificada.

\subsubsection{Macromorfologia dos Cupinzeiros}

\subsubsection{Descrição das estruturas nos cupinzeiros e no solo}

\section{Morfologia geral}

Os cupinzeiros podem ser divididos em três partes (Figura 4):

(1) Zona epígea com maior volume.

(2) Base do cupinzeiro, cilíndrica, não presente em todas as estruturas.

(3) Zona hipógea, região de contato direto com o solo, que sofre interferência de raizes e de outros organismos (evidenciada pela atividade de outros cupins, formigas e abundância de coprólitos).

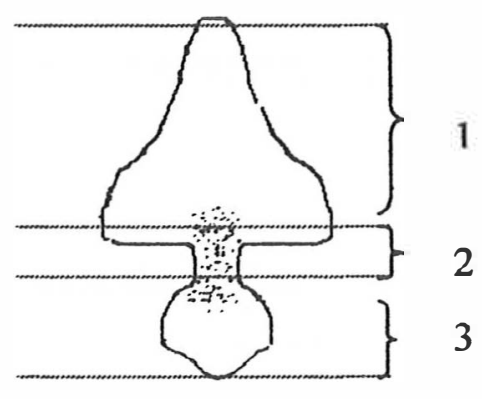

Figura 4. Morfologia interna de um cupinzeiro grande. 
De uma forma geral, os cupinzeiros estudados apresentam superficie preta e rugosa, com formato variando de irregular a regular cônico e base cilíndrica em contato com o solo (aspecto de "guarda-chuva"). Todos os menores ("P") são irregulares, ao passo que os maiores (" $G$ ") apresentam maior simetria. Podem apresentar de 1 a 4 pontas, com altura variando de 1 a $11 \mathrm{~cm}$. A altura da zona epígea varia de 15 a $49,5 \mathrm{~cm}$, o perímetro máximo de 10 a $104 \mathrm{~cm}$, o diâmetro máximo de 6 a $41 \mathrm{~cm}$ e a profundidade da zona hipógea 4 a $12 \mathrm{~cm}$ (Tabela 2). As respectivas estruturas estão ilustradas nas Figuras 5, 6, 7 e 8.

A partir dos cupinzeiros irradiam um conjunto de galerias sub-horizontais e verticais, que podem atingir até 1 metro de profundidade.

Quanto a resistência, os cupinzeiros pequenos são facilmente destruídos com a força das mãos. A fragilidade dos montículos diminui quanto maior o volume, sendo os cupinzeiros grandes muito resistentes à força humana. No entanto, para todas as classes de tamanho observa-se material erodido, no solo, oriundo das estruturas. É importante notar que, independente do tamanho, apresentam uma série de protuberâncias e terminações, que são facilmente destruídas.

Tabela 2 - Morfologia dos cupinzeiros representativos da área total.

\begin{tabular}{|c|c|c|c|c|c|c|c|c|c|}
\hline Cupinzeiro & $P_{1}$ & $P_{2}$ & $P_{3}$ & $I_{1}$ & $I_{2}$ & $I_{3}$ & $G_{1}$ & $G_{2}$ & $G_{3}$ \\
\hline Formato* & I & I & I & I & SI & I & $\mathrm{H}$ & $\mathrm{H}$ & $\mathrm{H}$ \\
\hline $\mathrm{N}^{0}$ de pontas & 4 & 1 & 1 & 3 & 3 & 1 & 4 & 3 & 2 \\
\hline Altura das pontas & $\begin{array}{c}11,0 \\
11,0 ; 7,0 \\
6,0\end{array}$ & 2,0 & - & $\begin{array}{c}10,5 ; 4,5 \\
2,5\end{array}$ & $\begin{array}{c}7,5 ; 5,5 ; \\
1,5\end{array}$ & 1,0 & 7,0 & $\begin{array}{c}6,5 ; 3,5 ; \\
2,5\end{array}$ & $\begin{array}{l}5,0 \\
5,0\end{array}$ \\
\hline Altura zona epígea & 15,0 & 16,5 & 15,5 & 31,0 & 31,5 & 31,0 & 46,5 & 49,5 & 43,0 \\
\hline Profundidade zona hipógea & & & 4,0 & 10,0 & 5,0 & 6,4 & 9,0 & 9,0 & 12,0 \\
\hline Perímetro máximo & 24,0 & 27,0 & 19,0 & 58,0 & 40,0 & 54,0 & 99,5 & 94,0 & 1040 \\
\hline Diâmetro máximo & 10,0 & 10,0 & 6,0 & 20,5 & 14,5 & 17,0 & 41,0 & 32,0 & 36 \\
\hline Diâmetro mínimo & 7,0 & 8,0 & 5,0 & 15,5 & 13,0 & 11,0 & 29,0 & 23,0 & 29 \\
\hline
\end{tabular}

*"I" = irregular; "SI"= semi-irregular; " $\mathrm{H} "=$ orto multi pontas. 


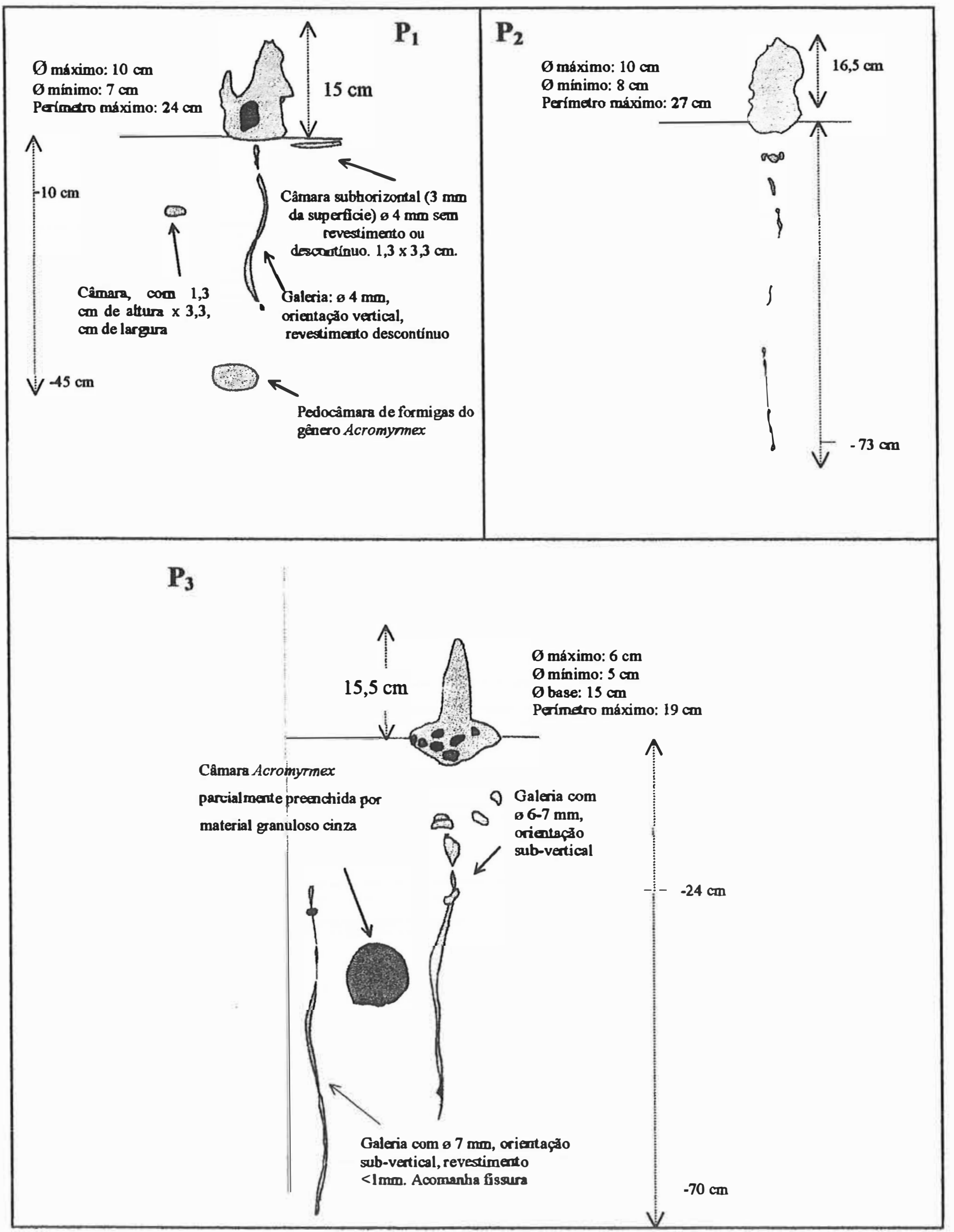

Figura 5. Morfologia dos cupinzeiros $P_{1}, P_{2}$ e $P_{3}$. 


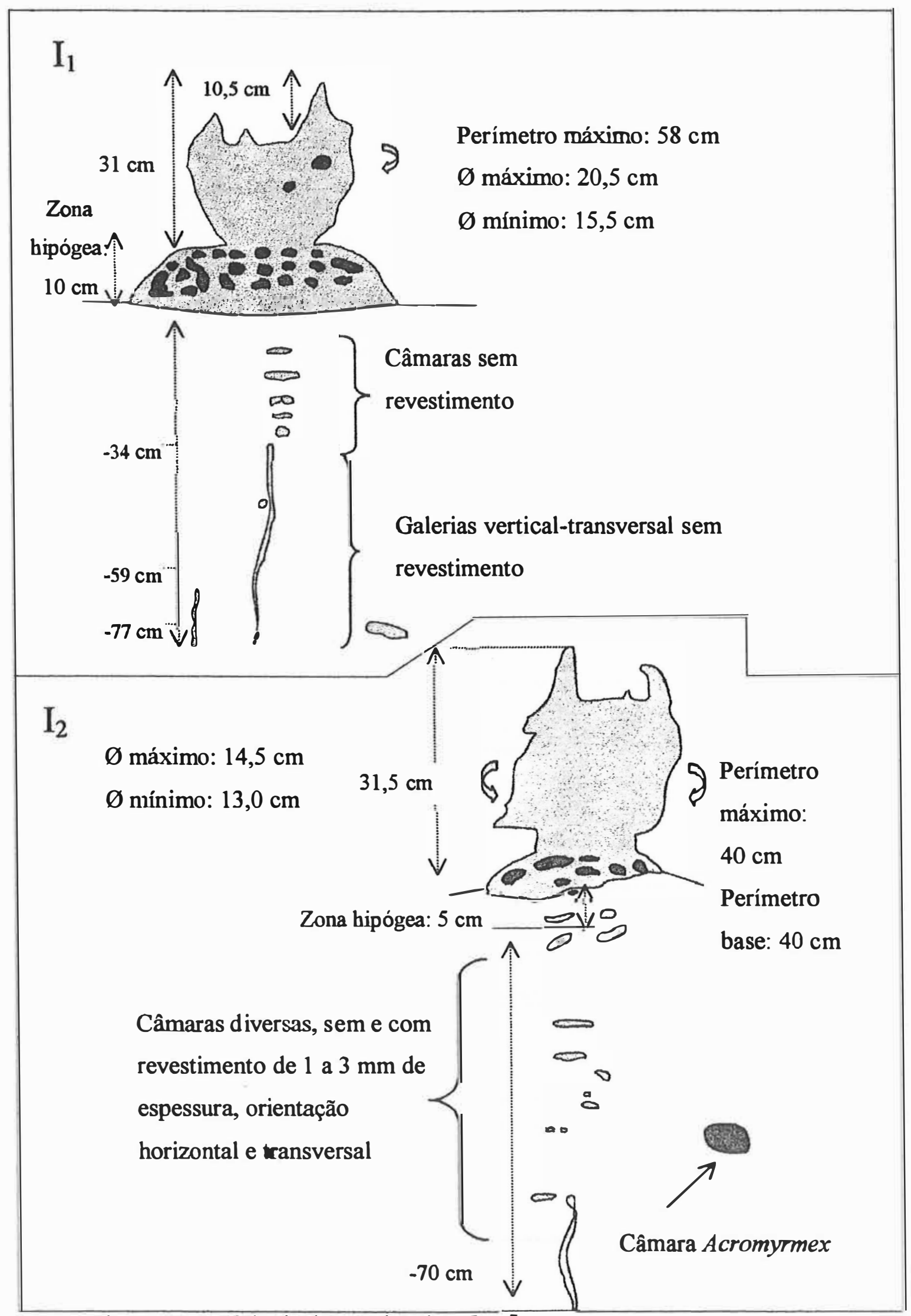

Figura 6. Morfologia dos cupinzeiros $\mathrm{I}_{1}$ e $\mathrm{I}_{2}$ 


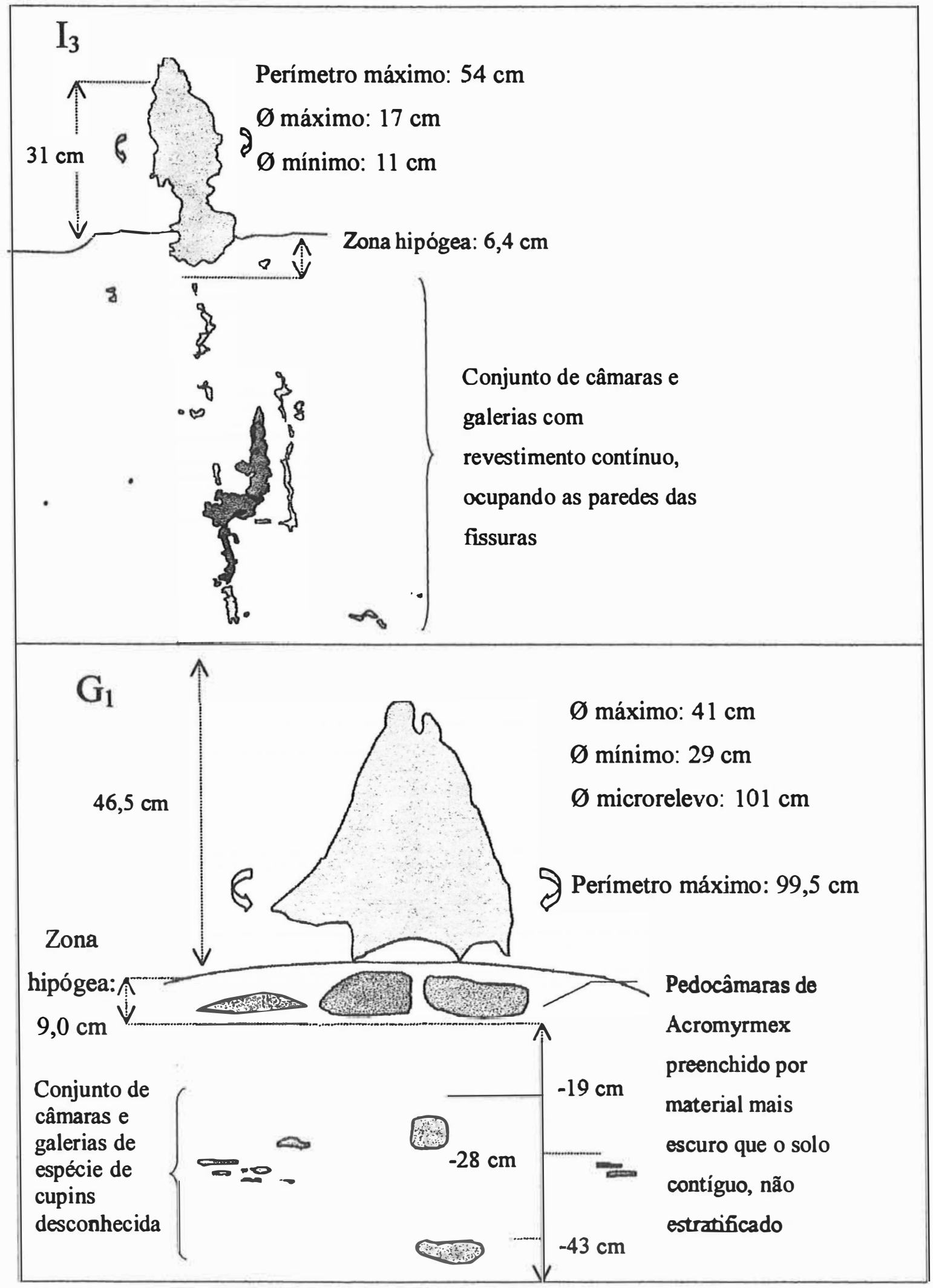

Figura 7. Figura. Morfologia dos cupinzeiros $I_{3}$ e $G_{1}$ 


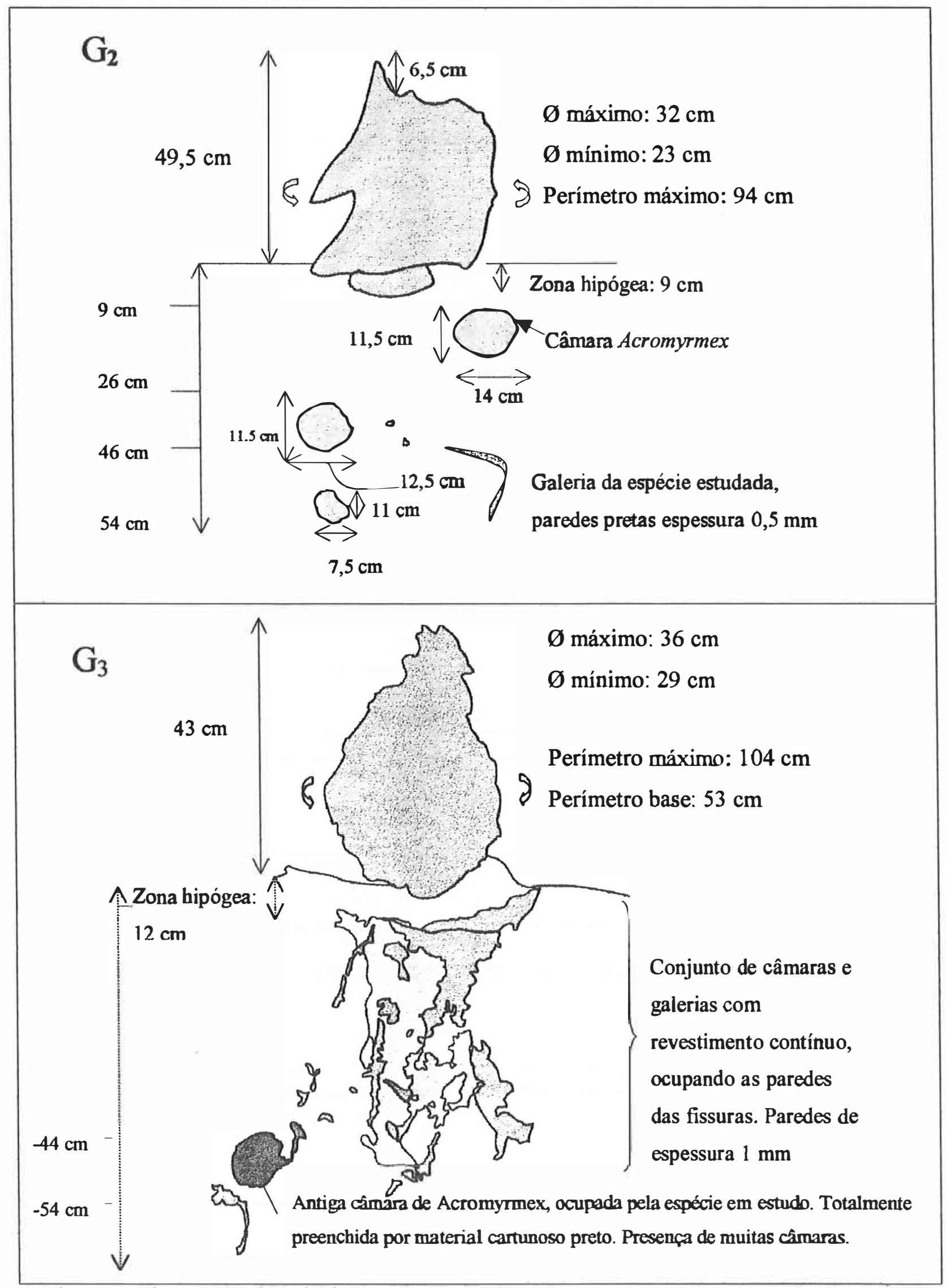

Figura 8. Figura. Morfologia dos cupinzeiros $\mathrm{G}_{2} \mathrm{e}_{3}$ 
Detalhamento das estruturas

Para descrição detalhada, foram observados os seguintes aspectos, nas diferentes regiões dos cupinzeiros (Apêndice 3):

a. Muralha externa: aspecto, espessura, cor;

b. Câmaras: localização, orientação, formato (volume e seção), dimensões, espessura da parede, aspecto da parede (rugosidade e deposições: cor, tipo de material, predominância, formato, dimensões), espessura da parede união dos vértices das paredes, conexões câmaras (localização e dimensões).

\section{c. Galerias}

\section{a. Muralha Externa}

Apresenta aspecto rugoso, de espessura mínima $0,2 \mathrm{~cm}$, média $0,4 \mathrm{~cm}$, podendo chegar a $1,2 \mathrm{~cm}$ nas protuberâncias. Cor variando do cinza escuro (sítios de aspecto liso) ao preto (sítios de maior rugosidade e de aspecto granular).

\section{b. Câmaras - descrição geral}

Entre classes de tamanho, as câmaras apresentam poucas variações em suas formas e dimensões. A orientação geral das câmaras é horizontal, e estão distribuídas descontinuamente, porém com certa simetria, pelos cupinzeiros (Figuras 23 e 27). São elipsoidais em sua maioria, de cor mais escura que a muralha externa.

A orientação das câmaras é horizontal a oblíqua. Apresentam, no mínimo, 2 conexões de formato cilíndrico. A seção é oval achatada, com $1,6 \mathrm{~mm} \times 0,8 \mathrm{~mm}$. Algumas variações são observadas por classe de tamanho e nas diferentes regiões dos cupinzeiros.

Os cupinzeiros da classe "P" possuem câmaras com formatos similares aos "G", todavia de menor tamanho (médias 2,0 cm de largura, $1,0 \mathrm{~cm}$ de altura e $1,3 \mathrm{~cm}$ de seção). As deposições ("pelotas") ocorrem em menor quantidade, predominando as brunas. Nesta classe não existe câmara real. 
As câmaras das classes "I" e "G" têm maior similaridade entre si. A cor predominante das paredes é preta, com deposições de material mineral vermelho, cinza, bruno, branco e preto. Estas deposições estão melhor detalhadas no item "Tipologia das Pelotas".

As seguintes regiões foram descritas:

Região da Muralha externa: a inclinação das câmaras acompanha o contorno da muralha. Possuem formato irregular, cupular, elipsoidal, piramidal (com 4 faces), tetraédrico ( 5 faces) e trapezoidal (ângulo obtuso entre teto/piso e paredes). $\mathrm{O}$ teto e o piso podem ser plano horizontal ou côncavo, irregulares e/ou de 2 faces (triangulares). Estes podem se unir no fundo da câmara, formando uma aresta ou uma pequena concavidade. As câmaras possuem dimensões variáveis. A largura varia de $1,7 \mathrm{~cm} \mathrm{a} \mathrm{4,5}$ $\mathrm{cm}$, altura de 1,0 a $1,8 \mathrm{~cm}$ e diâmetro de $1,2 \mathrm{~cm}$ a $2,5 \mathrm{~cm}$. As paredes têm espessuras que variam de 0,1 a $0,5 \mathrm{~cm}$, média de $0,2-0,3 \mathrm{~cm}$. A espessura entre os vértices das câmaras pode chegar a $1,0 \mathrm{~cm}$.

Região da câmara real: as câmaras são menores que as citadas anteriormente, com 0,8 a $1,5 \mathrm{~cm}$ de largura por 0,5 a 1,2 de altura e seção média de 2,0 cm. A espessura média da parede é $0,5 \mathrm{~cm}$, podendo variar de 0,1 a $0,9 \mathrm{~cm}$. As paredes são lisas com deposições localizadas nos vértices das câmaras. Esta região aparenta maior compacidade, pela maior espessura de paredes e menor tamanho das câmaras.

Especialmente a câmara real tem formato cupular, de teto côncavo e piso horizontal. Possui paredes de 0,3-0,5 cm de espessura, com $1,5 \mathrm{~cm}$ entre vértices (Figura 27). Este tipo de câmara não foi observado nos cupinzeiros pequenos.

Zona Hipógea: a região do cupinzeiro em contato com a superfície do solo apresenta alta rugosidade, com protuberâncias de $0,6 \mathrm{~cm}$ até $1 \mathrm{~cm}$. As câmaras possuem superficie lisa ou pouco rugosa. São irregulares ou denticuladas, elipsoidais ou tronco-tetraédricas, com vértices côncavos. $\mathrm{O}$ teto, o chão e as paredes são côncavos e têm espessura média $0,2 \mathrm{~cm}$. 
Câmaras no Solo: são encontradas em todo o perfil, em tamanhos que variam de 1 a 2 $\mathrm{cm}$ de largura por $1 \mathrm{~cm}$ de altura, diâmetro $0,4 \mathrm{~cm}$ a $1 \mathrm{~cm}$, com ou sem revestimento de paredes, conectadas às galerias (Figuras 21, 25 e 26).

Especificamente na trincheira referente ao cupinzeiro $G_{3}$ (Figura 21), à 44 cm da superficie, observa-se a ocorrência de uma câmara formada por formigas do gênero Acromyrmex, de formato semicircular e diâmetro $10 \mathrm{~cm}$. Está preenchida por um conjunto de câmaras de cupins estudados. As câmaras de Armitermes estão dispostas horizontalmente, são elipsoidais, regulares, com $2,9 \mathrm{~cm}$ de comprimento por $0,6 \mathrm{~cm}$ de altura. São pretas, de aspecto cartunoso, com pouca rugosidade e limite abrupto com o solo. As paredes têm espessura mínima 0,016 e máxima $0,12 \mathrm{~cm}$. Nestas, observam-se deposições de material mineral de cores diversas e orifícios de conexão entre câmaras, regulares, com formato elipsoidal, de seção $0,28 \mathrm{~mm} \times 0,32 \mathrm{~mm}$.

\section{c. Galerias}

A orientação predominante é vertical, no entanto ocorrem galerias subhorizontais próximas à superfície. São tubulares, com diâmetro que varia de 0,4 a 0,7 $\mathrm{cm}$. O revestimento das paredes pode ser preto, com espessura média $0,1 \mathrm{~cm}$, cinza escuro, descontínuo ou "ausente" (com deposições discóides, de mesma cor que o solo, observáveis apenas com o auxílio de lupa). O limite com o solo pode ser difuso, gradual ou abrupto, dependendo da espessura e do tipo de revestimento. A maioria das galerias superficiais apresentam revestimento, ao passo que as localizadas no horizonte plíntico têm revestimento descontínuo de mesma cor que o solo. Foram encontradas em até 1 metro de profundidade.

É comum encontrar no perfil conjunto de câmaras e galerias interconectadas, anastomose de galerias (Figuras 21 e 25) e pedotúbulos.

Algumas fissuras estão parcialmente revestidas por material preto ou cinza, de superfície ondulada e espessura média $0,03 \mathrm{~cm}$. A transição da maior para a menor cimentação do material preto ou cinza é gradual. $O$ revestimento é constituído por deposições de diferentes formatos e espessuras (ver ítem 5.1.3). O limite da fissura com 
o solo é abrupto ou gradual. Observou-se poros com 0,024 cm, e muitas radicelas de seção $0,027 \mathrm{~cm}$, formando uma trama sobre a superficie trabalhada pelos cupins.

\subsubsection{Meso e Micromorfologia dos Cupinzeiros - Tipologia das deposições dos cupins}

\subsubsection{Observações mesomorfológicas das deposições}

As "pelotas termíticas", quando regurgitadas ou excretadas, são liberadas na forma pastosa. Nesta condição, os operários são capazes de moldar as deposições de acordo com a pressão exercida com o hypofarynx. Desta forma, podem ser esferoidais, elipsoidais, ovoidais, cupulares, discóides, regulares ou irregulares, de superficie lisa ou ondulada. Especialmente as discóides são de maior tamanho, pela forte pressão exercida pelos cupins, apresentando superfície rugosa. As dimensões variam com o formato das deposições (Figuras 29 a 38).

Quanto a coloração, podem ser cinzas, brancas, brunas, vermelhas de diferentes tonalidades, e pretas.

As deposições "coloridas" (todas as cores excetuando as pretas), discóides (bem amassadas à parede), têm diâmetros que variam de 0,07 a 0,12 cm, algumas com pequena espessura de 0,01 a $0,03 \mathrm{~cm}$ (Figuras 30 e 31).

As deposições coloridas esferoidais, elipsoidais, ovoidais, ou cupulares ("pelotas") apresentam diâmetro médio de 0,04 cm, e espessura de 0,02 a 0,05 cm (Figuras 32, 33 e 34).

As deposições pretas apresentam formato esferoidal, com diâmetro de 0,05 a 0,08 cm (Figura 36), ou não são perceptíveis, formando a quase totalidade das paredes de câmaras e galerias.

A organização das pelotas condiz com a classificação de Eschenbrenner (1986): justapostas, sem ou com poucos pontos de contato entre as pelotas (Figura 31); fortemente soldadas (coalescentes), formando numerosas cavidades mamelonadas, com muitas interconecções; coalescente com formação de poucas cavidades mamelonadas (Figura 38); coalescência completa, sem formação de cavidades (Figura 37). Esta última é a organização básica de todas as estruturas dos cupinzeiros. 
Nos cupinzeiros pequenos observou-se predominância de deposições brunas, ao passo que nos intermediários e grandes as deposições são das mais diversas cores. A quantidade aumenta quanto mais próximas estão as câmaras da câmara real. Deposições "coloridas" estão concentradas principalmente nos vértices das câmaras, geralmente com forte coalescência (Figuras 29 e 30). As pelotas pretas, pouco deformadas, são encontradas em estruturas em processo de obstrução (Figura 36). As observações condizem com Grassé (1984) e Eschenbrenner (1988).

Portanto, as pelotas escuras são elementos básicos para todas as construções dos cupinzeiros, desde a zona epígea até as câmaras e galerias encontradas no solo.

\subsubsection{Microestrutura das Pelotas (observações ao MEV)}

As pelotas com predominância de material mineral têm superficie lisa, constituída principalmente por empacotamento de caulinitas e micas (Figuras $41 \mathrm{~A}_{1} \mathrm{e}$ $\mathrm{A}_{2}$ ). $\mathrm{O}$ aspecto compacto é atribuído à organização das partículas pelo aparelho bucal dos cupins e revestimento por saliva (Figuras $39 \mathrm{~B}_{1}$ e $\mathrm{B}_{2}$ ). Apesar de algumas pelotas apresentarem coloração vermelha, geralmente atribuída à presença de óxidos de ferro, não foram observados cristais de hematita ou goethita. No entanto a presença do ferro é indicada, em pequenas concentrações, nas microanálises (Figura $39 \mathrm{~B}_{3}$ ). $\mathrm{O}$ ferro pode estar presente na forma amorfa, ou microcristalina, não possível de ser observado em microscopia de varredura.

As pelotas de origem orgânica e, consequentemente, as paredes das diversas estruturas têm superficie com maior rugosidade, devido a menor organização dos seus constituintes e maior quantidade aparente de grãos de quartzo (Figuras $39 A_{1}$, $A_{2}$ e $40 B_{2}, B_{3}$ ). Da mesma forma, observam-se grãos de quartzo nas paredes das câmaras, o que explica a maior rugosidade de ambas (Figura $40 \mathrm{~A}_{1}$ ).

As microanálises das pelotas escuras e das paredes das câmaras não acusam diferenças de composição. Têm predominância de sílica e alumínio, com pequenas quantidades de potássio, oriundo da muscovita (Figuras $40 \mathrm{~B}_{2}$ e $\mathrm{B}_{4}$ ). 
4.2. Dados para a estimativa dos estoques de elementos no solo e nos cupinzeiros

\subsubsection{Densidade e área ocupada pelos cupinzeiros}

Dentro da área mapeada, foram encontrados 152 cupinzeiros ativos, da espécie dominante, o que eqüivale a uma densidade de 608 por hectare. Ocupam apenas $5,12 \mathrm{~m}^{2}$ em $2500 \mathrm{~m}^{2}$, ou seja, $20,48 \mathrm{~m}^{2} \mathbf{h a}^{-1}(\mathbf{0 , 2 1} \%$ da área total).

\subsubsection{Estimativa do peso seco dos cupinzeiros}

A partir dos cupinzeiros pesados fora da área de amostragem, buscou-se a combinação dos dados morfológicos de melhor ajuste ao peso dos cupinzeiros. Dentro desta condição, o índice escolhido foi o produto da altura pelo perímetro máximo, que será chamado de Índice Morfológico (Im).

A estimativa do peso seco foi realizada pela equação de regressão "peso seco = $\mathrm{f}\left(\right.$ Índice Morfológico)" (Figura 9), cuja melhor equação $\left(\mathrm{r}^{2}=0,952\right)$ é:

$$
\text { Peso } \operatorname{seco}(g)=0,013(\mathrm{Im})^{1,5925}
$$

Os valores dos pesos secos individuais dos 152 cupinzeiros calculados com essa equação variam de $18 \mathrm{~g}$ (altura: 12,5 cm; perímetro: 7,5 cm) até 15,2 kg (altura: 49,7 cm; perímetro: $130 \mathrm{~cm}$ ). No total, estimou-se que os cupinzeiros concentram $445,8 \mathrm{~kg}$ de material, o que eqüivale a $1,78 \mathbf{t ~ h a}^{-1}$. A partir deste valor será estimado o estoque de todos os elementos presentes nos cupinzeiros. 


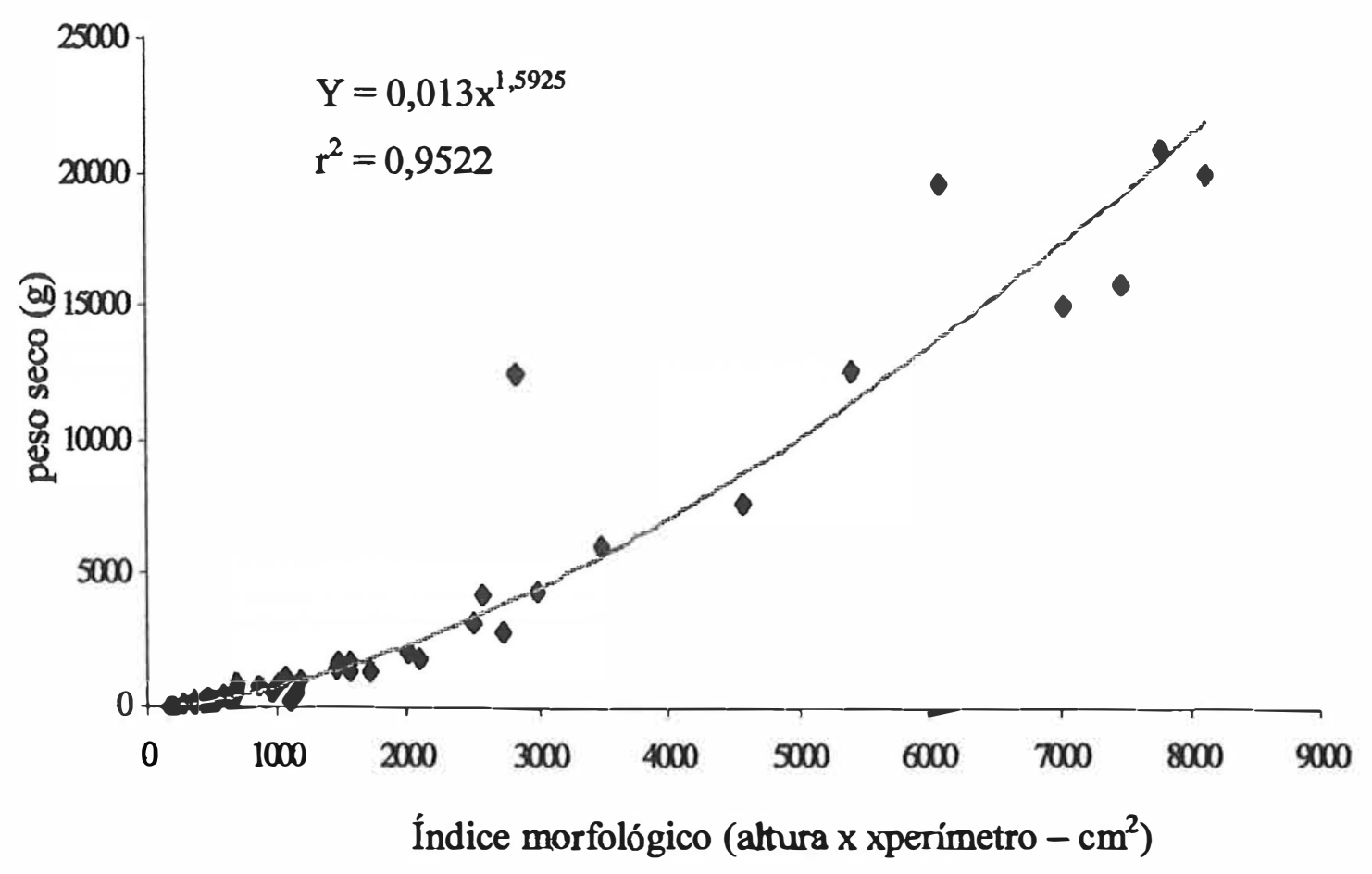

Figura 9. Relação altura x peso seco dos cupinzeiros.

\subsubsection{Estimativa da densidade dos cupinzeiros e densidade aparente do solo}

Para os cupinzeiros, a densidade aparente foi estimada através do peso seco e do volume dos montículos retirados fora da área de amostragem. Para a estimativa dos volumes, utilizou-se para todos os cupinzeiros a fórmula do volume de um cone $V=h \cdot \pi \cdot r^{2} / 3$. São estruturas pouco densas, devido sua morfologia interna, repleta de cârnaras (Tabela 3).

No solo, observa-se aumento da densidade aparente com a profundidade (Tabela 3). A menor densidade aparente da superfície explica-se pela abundância de raízes e maior teor de matéria orgânica.

A densidade aparente das diferentes profundidades do solo é a base para os cálculos das estimativas do estoque de elementos. 
Tabela. 3 - Densidade aparente das camada 0-15, 15-30 e 30-50 cm do solo, e estimativa da densidade aparente dos cupinzeiros.

\begin{tabular}{lcccc}
\hline & \multicolumn{4}{c}{ Profundidade $(\mathrm{cm})$} \\
Média $\left(\mathrm{g} \mathrm{cm}^{-3}\right)$ & $0-15$ & $15-30$ & $30-50$ & Cupinzeiros \\
\cline { 2 - 5 } $\mathrm{sd}^{*}$ & 1,12 & 1,39 & 1,42 & 0,74 \\
$\mathrm{~N}^{*}$ & $( \pm 0,05)$ & $( \pm 0,08)$ & $( \pm 0,06)$ & $( \pm 0,10)$ \\
\hline
\end{tabular}

*sd: desvio padrão da média; N: número de amostras.

\subsection{Composição Física, Mineralógica e Química dos Cupinzeiros e Solos Associados}

\subsubsection{Gramulometria}

No solo, a fração silte $(0,002-0,05 \mathrm{~mm})$ é predominante, compreendendo 45,0 a 49,4\% da totalidade do solo. A parcela correspondente à argila $(<0,002 \mathrm{~mm})$ compreende 29,7 a $39,6 \%$, seguida de areia total $(50 \mu \mathrm{m}-2 \mathrm{~mm})(15,0$ a $18,7 \%)$.

As areias foram separadas em 5 frações: muito grossa $(2-1 \mathrm{~mm})$, grossa (1-0,5 mm), média $(0,5-0,25 \mathrm{~mm})$, fina $(0,25-0,1 \mathrm{~mm})$ e muito fina $(0,1-0,05 \mathrm{~mm})$. Dentre as areias, a maior contribuição vem da fração muito fina $(10,8$ a $11,7 \%)$. O solo ainda apresenta uma pequena porção de areia fina $(3,3$ a 7,0 \%), com maiores teores na superficie do solo. Apenas a camada $0-15 \mathrm{~cm}$ possui fração grossa e média $(0,9$ e 2,2\%, respectivamente). Partículas de 2 a $1 \mathrm{~mm}$ (fração muito grossa) são ausentes no solo (Tabela 4, Figura 10).

A fração areia total $(2,0-0,05 \mathrm{~mm})$ e silte $(0,05-0,002 \mathrm{~mm})$ estão igualmente distribuídas nas diferentes profundidades do solo, a $p<0,05$. A fração areia fina tem maior concentração na camada $0-15 \mathrm{~cm}$. Em contrapartida, observa-se aumento progressivo nos teores de argila com a profundidade, diferindo estatisticamente a $5 \%$ de probabilidade. 
Quanto aos cupinzeiros, todas as frações apresentam teores próximos aos encontrados na camada $0-15 \mathrm{~cm}$ do solo.

Para as diferentes classes, o estudo dos cupinzeiros da classe "P" não foi realizado devido a escassez de material para análises granulométricas.

Comparando-se os cupinzeiros das diferentes classes ("I" e "G") aos solos associados, observa-se que o teor de argila nos cupinzeiros "I" é superior à camada 0-15 $\mathrm{cm}$, a $\mathrm{p}<0,05$ (Tabela 5). Os resultados evidenciam tendência a acúmulo de argila nos cupinzeiros em relação à camada $0-15 \mathrm{~cm}$.

Para a argila dispersa em água, maiores valores são encontrados na camada 0-15 cm. Em seguida, os cupinzeiros apresentam altos valores, mas diferindo da camada superficial, a $p<0,05$. Consequentemente, a superficie do solo tem o menor grau de floculação (Tabela 4).

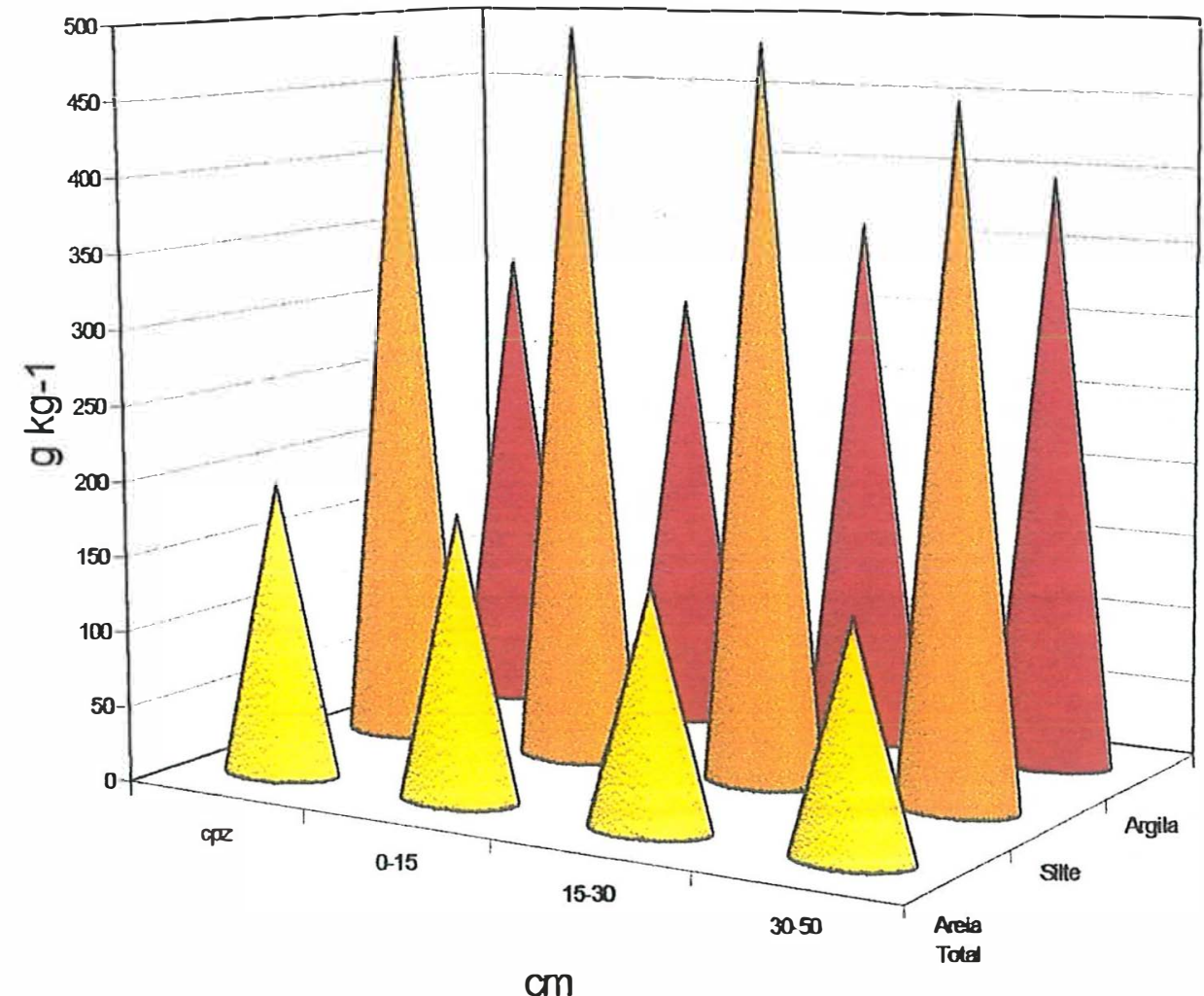

Figura 10 - Granulometria dos cupinzeiros (cpz) e nas diferentes profundidades do solo 
Tabela 4 - Granulometria dos cupinzeiros e nas diferentes profundidades do solo (média seguida do desvio padrão, $\mathrm{p}<0,05$ ).

\begin{tabular}{|c|c|c|c|c|c|c|c|c|c|c|}
\hline & \multicolumn{6}{|c|}{ Areia* } & \multirow[t]{2}{*}{ Silte } & \multicolumn{2}{|c|}{ Argila } & \multirow[t]{2}{*}{ Floc. } \\
\hline & $M G$ & $G$ & $M$ & $F$ & $M F$ & Total & & Total & $\begin{array}{l}\text { Dipora } \\
\text { em Ágga }\end{array}$ & \\
\hline & \multicolumn{6}{|c|}{$g k^{-1}$} & & & & $\%$ \\
\hline \multirow[t]{2}{*}{ Cupinzeiro } & 0,0 & $13,3 \mathrm{a}$ & $20,0 a$ & $61,1 a b$ & $101,1 a$ & $195,6^{\circ}$ & $485,6 a$ & 318,9 & 10676 & 66,96 \\
\hline & 8 & $\pm 7,1$ & & $\pm 14,5$ & $\pm 16,6$ & $\pm 21,9$ & $\pm 16,7$ & $\pm 10,5$ & $\pm 10,5$ & $\pm 2,3$ \\
\hline \multirow[t]{2}{*}{$0-15 \mathrm{~cm}$} & 0,0 & $8,9 a$ & $22,2 \mathrm{a}$ & $70,0 \mathrm{a}$ & $107,8 \mathrm{a}$ & $186,7^{\mathrm{a}}$ & $494,4 a$ & $296,7 b c$ & $173,3 a$ & $41,7 \mathrm{c}$ \\
\hline & & $\pm 9,3$ & $\pm 13,0$ & $\pm 11,2$ & $\pm 22,2$ & $\pm 70,0$ & $\pm 19,4$ & $\pm 23,5$ & $\pm 17,3$ & $\pm 3,1$ \\
\hline \multirow[t]{2}{*}{$15-30 \mathrm{~cm}$} & 0,0 & $0,0 \mathrm{~b}$ & $0,0 \mathrm{~b}$ & $45,6 \mathrm{bc}$ & $108,9 a$ & $154,4^{\mathrm{a}}$ & $487,8 \mathrm{a}$ & 357,86 & $57,8 \mathrm{c}$ & $83,7 \mathbf{a}$ \\
\hline & & & & $\pm 15,1$ & $\pm 14,5$ & $\pm 20,1$ & $\pm 21,7$ & $\pm 23,3$ & $\pm 12,0$ & $\pm 3,7$ \\
\hline \multirow[t]{2}{*}{$30-50 \mathrm{~cm}$} & 0,0 & $0,0 \mathrm{~b}$ & $0,0 \mathrm{~b}$ & $33,3 \mathrm{c}$ & $116,7 a$ & $150,0^{\mathrm{a}}$ & $454,4 \mathrm{~b}$ & $395,6 a$ & $44,4 \mathrm{c}$ & $88,8 \mathrm{a}$ \\
\hline & & & & $\pm 11,2$ & $\pm 20,0$ & $\pm 18,0$ & $\pm 24,5$ & $\pm 29,6$ & $\pm 29,6$ & $\pm 6,3$ \\
\hline
\end{tabular}

*MG= muito grossa; $\mathrm{G}=$ grossa; $\mathrm{M}=$ média; $\mathrm{F}=$ fina; $\mathrm{MF}=$ =muito fina; Total= areia total;

** médias seguidas da mesma letra não diferem pelo teste Tukey a 5\%.

Tabela 5 - Granulometria das diferentes classes de cupinzeiros e dos solos associados (média seguida do desvio padrão, $\mathrm{p}<0,05$ ) .

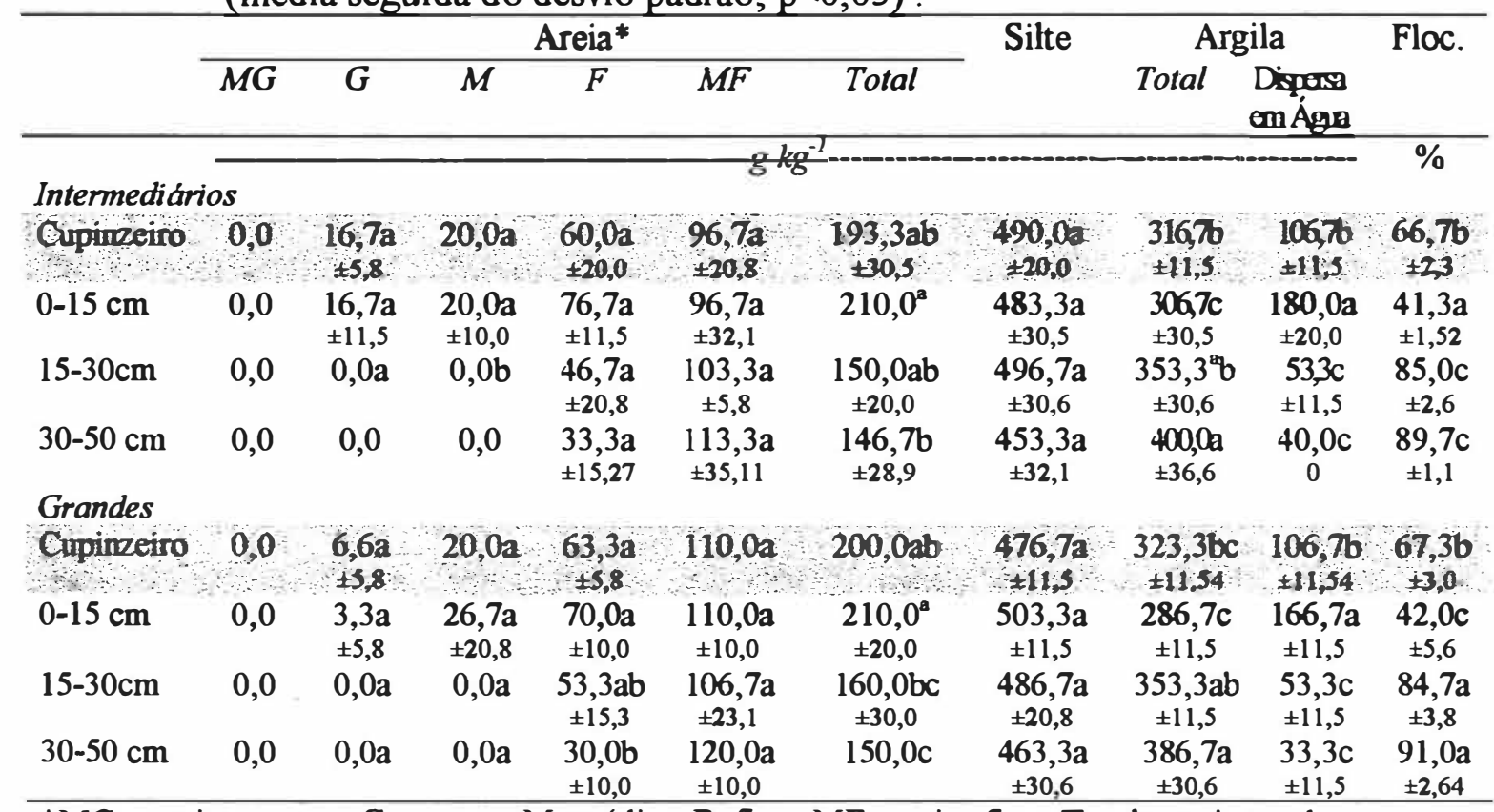

* $\mathrm{MG}=$ muito grossa; $\mathrm{G}=$ grossa; $\mathrm{M}=$ média; $\mathrm{F}=$ fina; $\mathrm{MF}=$ muito fina; Total= areia total;

** médias seguidas da mesma letra, entre classes (na vertical), não diferem pelo teste Tukey a $5 \%$. 


\subsubsection{Mineralogia}

As observações em lupa binocular da fração areia indicam a predominância do quartzo nos cupinzeiros e no solo, associado a pequenas quantidades de concreções de ferro, micas (muscovita) e anatásio.

A difratometria de raios - $X$, das frações silte grosso $(0,02-0,05 \mathrm{~mm})$ e silte fino $(0,002-0,02 \mathrm{~mm})$ indica a predominância de quartzo em todas as amostras, identificado pelos picos principais 4,26 e 3,34 $\AA$. A elevada intensidade dos picos do quartzo mascaram a ocorrência de outros minerais, no entanto há traços de goethita, ilita, muscovita e anatásio. Para a fração argila $(<0,002 \mathrm{~mm})$, em todas as profundidades e no cupinzeiro, houve predominância de caulinita, identificada pelos picos 7,22 - 7,23 e 3,59 Å. Em seguida, verificou-se a ocorrência de quartzo, muscovita ( espaçamento basal ao redor de $10 \AA$ ), vermiculita (14 - 14,6 $\AA$ ), e mineral interestratificado mica-vermiculita $(22-24 \AA)-($ Figuras 11 e 12).

A caracterização mineralógica global não indica seleção preferencial de minerais pelos cupins, nas diferentes profundidades do solo. No entanto, observa-se menor intensidade do pico de caulinita não tratada da camada $0-15 \mathrm{~cm}$, em relação às camadas $15-30,30-50 \mathrm{~cm}$ e cupinzeiros. 

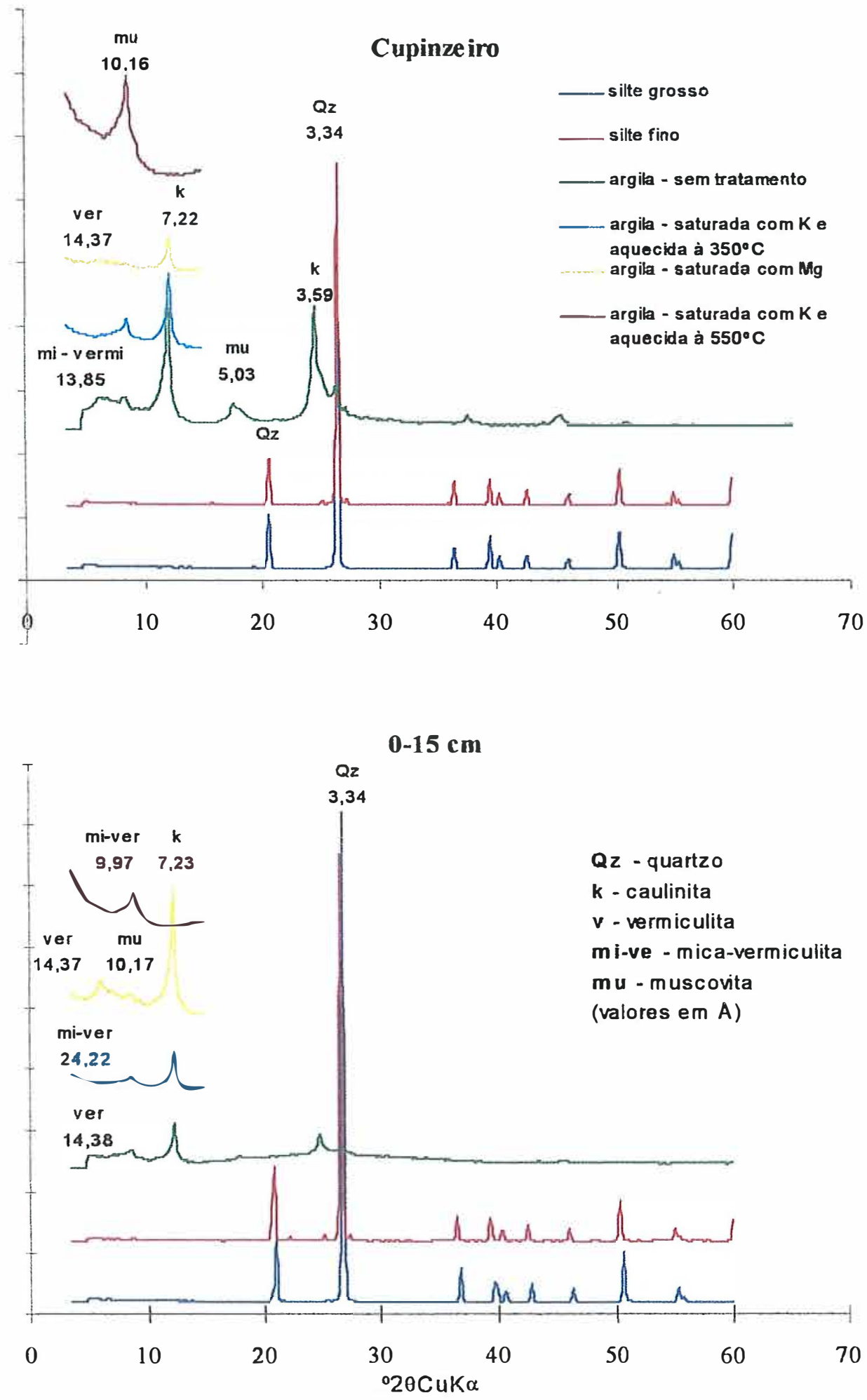

Figura 11 - Difratogramas de raios - $\mathrm{X}$ das frações silte grosso, silte fino e argila, dos cupinzeiros e da camada $0-15 \mathrm{~cm}$ do solo. 

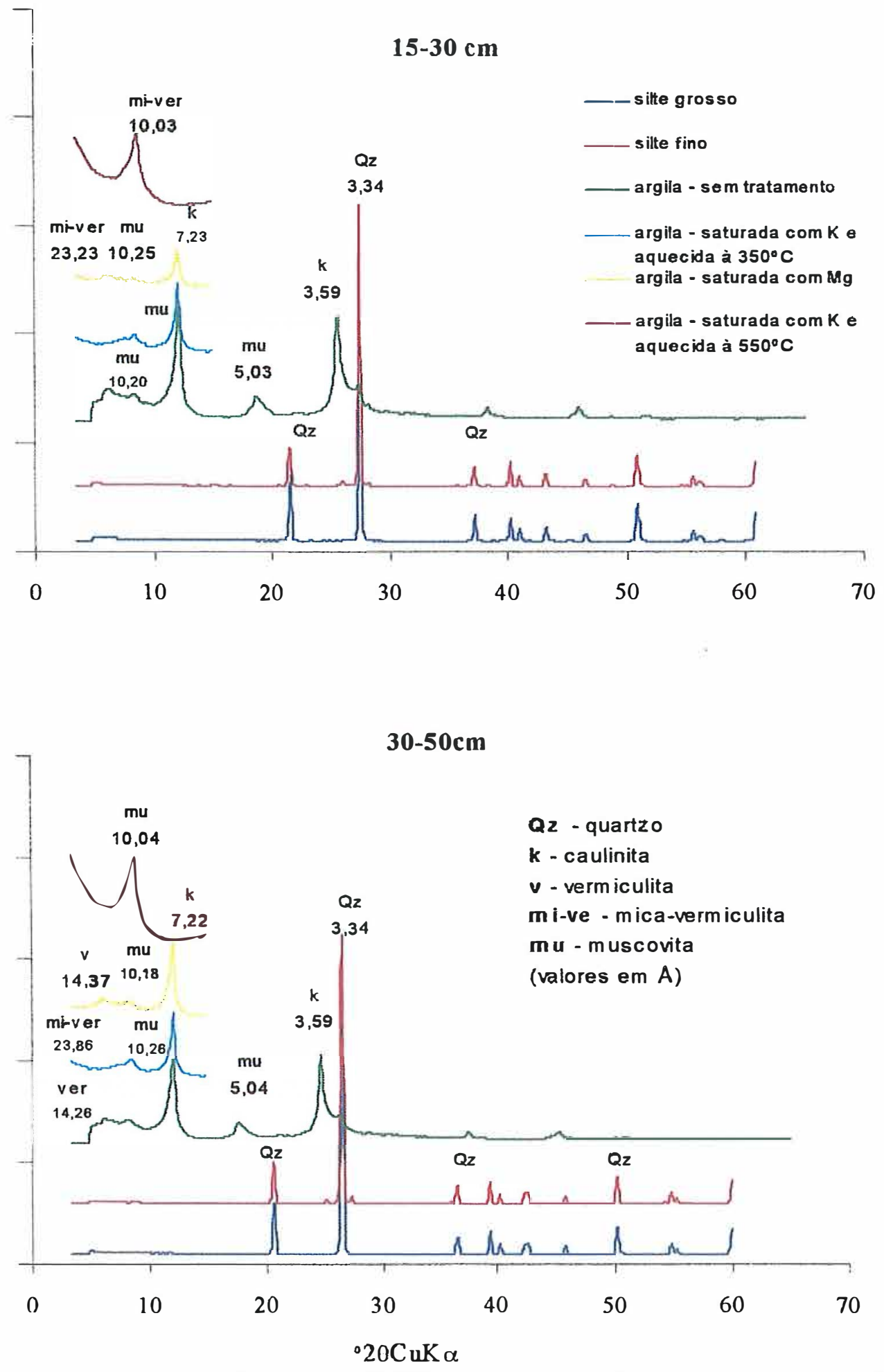

Figura 12 - Difratogramas de raios - $\mathrm{X}$ das frações silte grosso, silte fino e argila das camada $15-30$ e $30-50 \mathrm{~cm}$ do solo. 


\subsubsection{Composição Química - C orgânico, $p H, P-P O 4^{-3}$ e cátions trocáveis}

\subsubsection{Carbono Orgânico}

Os teores médios no solo variam de 5,39 a $23,08 \mathrm{~g} \mathrm{~kg}^{-1}$, sendo maior o acúmulo na camada $0-15 \mathrm{~cm}$ do solo a $\mathrm{p}<0,05$. Em subsuperfície, o acúmulo de $\mathrm{C}$ é menor, não havendo diferença estatística entre as camadas $15-30$ e $30-50 \mathrm{~cm}$. O mesmo é observado quando é considerado o solo por classes de altura ("P", " $\mathrm{T}$ " " $\mathrm{G}$ "),

Em relação aos cupinzeiros, o teor de carbono é 3,3 vezes superior ao da camada superficial do solo (Tabela 6, Figura 13).

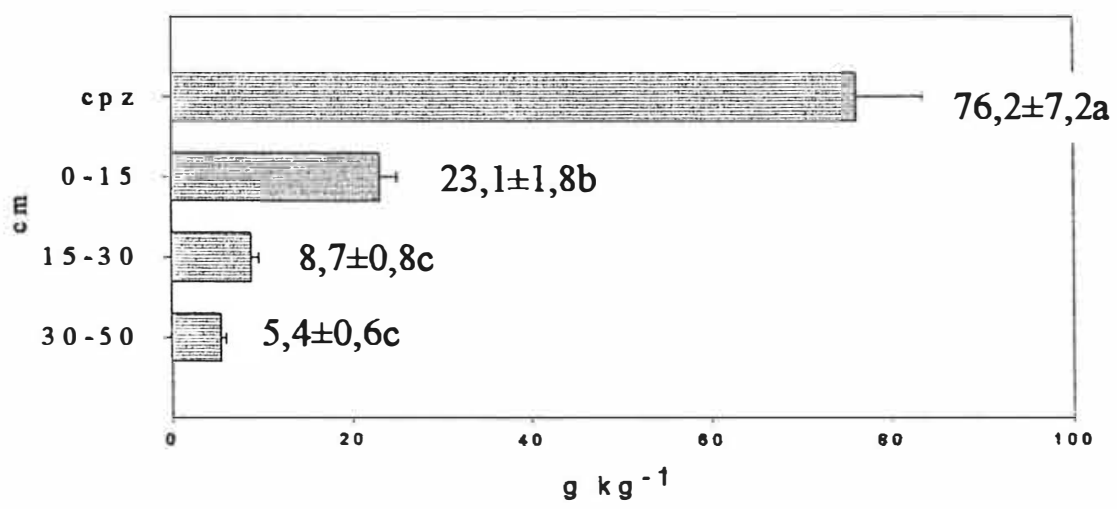

Figura 13 - Teores de carbono nos cupinzeiros e no solo (amostra total)

Os cupinzeiros das diferentes classes de tamanho não diferem entre si no teor de $\mathrm{C}$ a $\mathrm{p}<0,05$, porém observa-se a tendência a maior acúmulo nos cupinzeiros grandes (Figura 14). 
Tabela 6. Teores de carbono nas diferentes classes de cupinzeiros e solos*.

\begin{tabular}{|c|c|c|c|c|}
\hline & $0-15 \mathrm{~cm}$ & $15-30 \mathrm{~cm}$ & $30-50 \mathrm{~cm}$ & Cupinzeiros \\
\hline & \multicolumn{4}{|c|}{ - } \\
\hline Pequenos & $24,5 \pm 1,32 b$ & $8,38 \pm 0,68 c$ & $5,41 \pm 0,48 c$ & $69,63 \pm 5,93 a A$ \\
\hline Intermediários & $21,83 \pm 1,82 b$ & $8,99 \pm 1,14 \mathrm{c}$ & $5,65 \pm 0,97 c$ & $77,63 \pm 4,72 \mathrm{aA}$ \\
\hline Grandes & $22,9 \pm 1,73 b$ & $8,35 \pm 0,70 c$ & $5,11 \pm 0,27 \mathrm{c}$ & $81,47 \pm 6,44 a A$ \\
\hline
\end{tabular}

*Médias seguidas pela mesma letra minúscula, na horizontal, e maiúscula, na vertical, não diferem pelo teste de Tukey a $5 \%$.

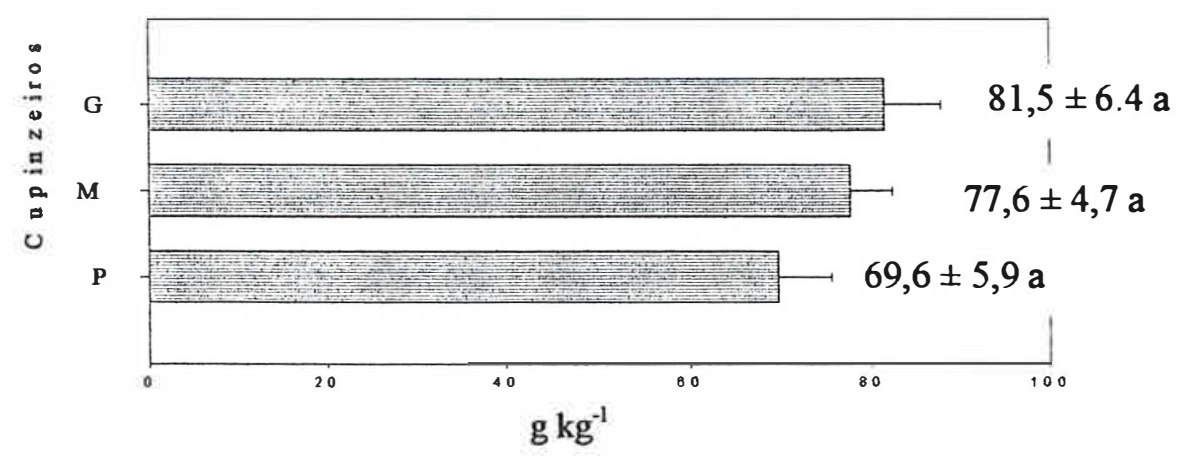

Figura 14 - Teores de carbono nos cupinzeiros e no solo, segundo as classes definidas: pequenos ("P"), intermediários (" $\mathrm{T}$ ") e grandes (“G”). Médias seguidas pela mesma letra não diferem pelo teste de Tukey a $5 \%$.

Apesar do acúmulo de $\mathrm{C}$ nos montículos, a contribuição dos cupinzeiros para o estoque global de carbono é mínimo $\left(13,6 \mathrm{~g} \mathrm{~m}^{-2}\right.$ ou $\left.136 \mathrm{~kg} \mathrm{ha}^{-1}\right)$ em comparação a do solo (7240 $\mathrm{g} \mathrm{m}^{-2}$ ou 72,4 ton ha ${ }^{-1}$ na camada $0-50 \mathrm{~cm}$ ) - (Tabela 7).

Os estoques encontrados nos cupinzeiros foram relacionados à camada 0 $15 \mathrm{~cm}$ do solo, considerando esta homogênea para todos os elementos estudados. Os cálculos simplificados expressam os estoques em milímetros de terra pertencente a esta camada. Os estoques de carbono dos cupinzeiros correspondem, portanto, a $1,9 \mathrm{~mm}$ da camada $0-15 \mathrm{~cm}$ do solo. 
Tabela 7. Estoque e balanço de carbono nos cupinzeiros e no solo.

\begin{tabular}{cccccccc}
\hline & \multicolumn{3}{c}{ Estoque de C } & & \multicolumn{2}{c}{ Balanço de C } \\
$0-15 \mathrm{~cm}$ & $15-30 \mathrm{~cm}$ & $30-50 \mathrm{~cm}$ & $0-50 \mathrm{~cm}$ & $\mathrm{Cpz}^{*}$ & & Cpz. & Solo $-0-50 \mathrm{~cm}$ \\
\hline 3,89 & 1,82 & 1,53 & 7,24 & 0,0136 & & 0,187 & 99,812 \\
\hline
\end{tabular}

${ }^{*} \mathrm{cpz}$ : cupinzeiro

\subsubsection{2 pH (Tabela 8, Figura 15)}

O solo apresenta $\mathrm{pH} \mathrm{CaCl}$ variando de 3,85 a $3,78 . \mathrm{O} \mathrm{pH}$ em $\mathrm{KCl}$ tem valores próximos aos determinados em $\mathrm{CaCl}_{2}$, e o $\mathrm{pH}$ em água, com valores de aproximadamente 1 unidade acima dos encontrados em $\mathrm{CaCl}_{2}$ e $\mathrm{KCl}$. Constitui-se, portanto, num solo de elevada acidez. A diferença entre o $\mathrm{pH}$ em $\mathrm{KCl}$ e $\mathrm{H}_{2} \mathrm{O}$ (valores negativos) indica a predominância de cargas negativas no solo.

Os cupinzeiros apresentam $\mathrm{pH}$ 's de menor acidez que o solo $\left(\mathrm{pHCaCl}_{2}=\right.$ 4,$51 ; \mathrm{pH} \mathrm{KCl}=4,51$ e $\mathrm{pH} \mathrm{H}_{2} \mathrm{O}=5,45$ ).

\subsubsection{3 $\mathrm{P}_{-} \mathrm{PO}_{4}^{-3}$ (resina)}

No solo, os teores $\mathrm{P}_{-} \mathrm{PO}_{4}{ }^{-2}$ diminuem com a profundidade, variando de 3,22 a $1,45 \mathrm{mg} \mathrm{kg}^{-1}$.

Nos cupinzeiros, $\mathrm{P}_{-\mathrm{PO}_{4}}^{-2}\left(4,78 \mathrm{mg} \mathrm{kg}^{-1}\right)$ é 1,48 vezes superior à camada 0 $15 \mathrm{~cm}$ do solo (Tabela 9). Entre as diferentes classes de cupinzeiros, não se observou diferenças estatísticas dos teores de $\mathrm{P}_{-} \mathrm{PO}_{4}{ }^{-2}$.

Apesar dos maiores teores de $\mathrm{P}$ nos cupinzeiros, estes contribuem muito pouco para o estoque global de $\mathrm{P}$ (Tabela 10). Estocam $0,85 \mathrm{mg} \mathrm{m}^{-2}$ (ou $8,5 \mathrm{~g} \mathrm{ha}^{-1}$ ), enquanto que a camada $0-15 \mathrm{~cm}$ contém $540 \mathrm{mg} \mathrm{m}^{-2}$ (ou $5,4 \mathrm{~kg} \mathrm{ha}^{-1}$ ). Os cupinzeiros correspondem, portanto, a $\mathbf{0 , 2 3} \mathrm{mm}$ da camada $0-15 \mathrm{~cm}$ do solo. 
4.3.3.4 Bases Trocáveis $\left(\mathrm{Ca}^{+2}, \mathrm{Mg}^{+2}, \mathrm{~K}^{+}, S B^{1}, \mathrm{CTC}\right.$ calculada e V\%)

No solo, os teores de $\mathrm{K}^{+}$variam de 0,65 a 0,97 $\mathrm{mmol}_{\mathrm{c}} \mathrm{kg}^{-1}, \mathrm{Ca}^{++}$de 1,44 a 2,33 $\mathrm{mmol}_{\mathrm{c}} \mathrm{kg}^{-1}, \mathrm{Mg}^{+2}$ de 1,00 a 1,22 $\mathrm{mmol}_{\mathrm{c}} \mathrm{kg}^{-1}$. A soma de bases varia de 2,77 a 4,21 mmol $_{\mathrm{c}} \mathrm{kg}^{-1}$, CTC calculada de 56,32 a 79,97 mmol $\mathrm{kg}^{-1} \mathrm{e}$ V\% de 4,56 a 7,33\% . Consiste, portanto, num solo de baixíssima fertilidade, com teores de nutrientes disponíveis principalmente pela presença de matéria orgânica na camada superficial, e minerais $2: 1$, de alta superficie específica, nas camadas subsuperficiais do solo. $\mathrm{K}^{+} \mathrm{e}$ CTC calculada são maiores em 0-15 cm, diferindo de $15-50 \mathrm{~cm}$ a p<0,05. Já $\mathrm{Ca}^{+2}$ e $\mathrm{Mg}^{+2}$ têm maiores concentrações na camada $30-50 \mathrm{~cm}$, indicando a contribuição da mineralogia do solo para os teores trocáveis destas bases (presença de muscovita, vermiculita e mineral interestratificado) e/ou translocação para subsuperficie. Por estas, a V\% do solo é maior em subsuperficie que em superficie, apesar desta diferença não ser estatisticamente confirmada.

Nos cupinzeiros observam-se as maiores concentrações de nutrientes. $\mathrm{O}$ teor de $\mathrm{K}^{+}\left(3,33 \mathrm{mmol}_{\mathrm{c}} \mathrm{kg}^{-1}\right)$ é 3,43 vezes superior que a camada $0-15 \mathrm{~cm}$ do solo, $\mathrm{Ca}^{+2}$ $\left(4,00\right.$ mmol $\left._{\mathrm{c}} \mathrm{kg}^{-1}\right)$ 2,78 vezes e $\mathrm{Mg}^{++}\left(4,56\right.$ mmol $\left._{\mathrm{c}} \mathrm{kg}^{-1}\right) 4$ vezes maior que na camada superficial do solo, diferindo desta a p<0,05 (Tabela 9, Figura 16).

Entre as diferentes classes de cupinzeiros, não se observou diferenças estatísticas dos teores de $\mathrm{Ca}^{+2}, \mathrm{Mg}^{+2}, \mathrm{SB}, \mathrm{T}$ e V\%. Os cupinzeiros grandes têm tendência ao acúmulo de $\mathrm{Ca}^{+2}, \mathrm{Mg}^{+2}$, tendo como conseqüência maior soma de bases.

Apesar dos maiores teores dos elementos nos cupinzeiros, estes contribuem muito pouco para o estoque global das bases trocáveis (Tabela 8 e 10). Os cupinzeiros correspondem, para o $\mathrm{K}^{+}, \mathbf{0 , 5 4} \mathbf{m m}$ da camada $0-15 \mathrm{~cm}$ do solo, para o $\mathrm{Ca}^{+2}$ $0,44 \mathrm{~mm}$ e para o $\mathrm{Mg}^{+2} 0,72 \mathrm{~mm}$.

\footnotetext{
${ }^{1}$ SB: Soma de bases
} 


\subsubsection{5 $\mathrm{H}^{+}, \mathrm{Al}^{+3}$ e $\mathrm{m} \%$}

No solo, $\mathrm{H}^{+}$é o íon dominante no complexo de troca, seguido de $\mathrm{Al}^{+3}$. Os teores de $\mathrm{H}^{+}$diminuem em profundidade, variando de 46,67 a $15,89 \mathrm{mmol}_{\mathrm{c}} \mathrm{kg}^{-1}$. Já $\mathrm{Al}^{+3}$ aumenta com a profundidade, variando de 29,78 a 36,22 mmol $_{\mathrm{c}} \mathrm{kg}^{-1}$.

Os teores de $\mathrm{Al}^{+3}$ nos cupinzeiros diferem estatisticamente do solo, sendo 2,7 vezes inferior à camada $0-15 \mathrm{~cm}$ e 6 vezes inferior à camada $30-50 \mathrm{~cm}$.

Entre as 3 classes de cupinzeiros, os teores de $\mathrm{Al}^{+3}$ e $\mathrm{m} \%$ também diferem a $\mathrm{p}<0,05$, tendo menor acúmulo do cátion trocável nos cupinzeiros grandes (Tabela 11). Entre as diferentes classes de cupinzeiros, não se observou diferenças estatísticas dos teores de $\mathrm{H}^{+}+\mathrm{Al}^{+3}$. No entanto, $\mathrm{Al}^{+3}$, e consequentemente $\mathrm{m} \%$ diminuem com o tamanho dos cupinzeiros, a $\mathrm{p}<0,05$ (Tabela 11).

\section{Síntese dos resultados químicos}

Observou-se acúmulo de $\mathrm{C}$, bases trocáveis e fósforo nos cupinzeiros As concentrações são 1,5 até 4,6 superiores a camada $0-15 \mathrm{~cm}$ do solo. $\mathrm{O}$ pH nos cupinzeiros acompanha o aumento dos teores, sendo superior em 1 unidade da camada $0-15 \mathrm{~cm}$ do solo. Já os teores de $\mathrm{Al}^{+3}$ são 2,7 vezes menores nos cupinzeiros, em relação à camada $0-15 \mathrm{~cm}$ do solo. Quanto aos estoques, os cupinzeiros contém quantidade ínfima de nutrientes quanto comparados ao solo (Tabela 12). 
Tabela 8 - Média dos valores de $\mathrm{pH}$ e dos teores de nutrientes, no solo e na totalidade dos cupinzeiros*.

\begin{tabular}{|c|c|c|c|c|c|}
\hline & \multicolumn{3}{|c|}{ Profundidade $(\mathrm{cm})$} & \multirow[t]{2}{*}{ Cupinzeiros } \\
\hline & & $0-15$ & $15-30$ & $30-50$ & \\
\hline \multicolumn{2}{|c|}{$\mathrm{pH} \mathrm{H}{ }_{2} \mathrm{O}$} & $4,82 \pm 0,23 b$ & $4,56 \pm 0,28 b$ & $4,67 \pm 0,21 b$ & $5,45 \pm 0,17 a$ \\
\hline \multicolumn{2}{|c|}{$\mathrm{pH} \mathrm{KCl}$} & $3,80 \pm 0,08 b$ & $3,75 \pm 0,07 b$ & $3,71 \pm 0,09 b$ & $4,51 \pm 0,16$ \\
\hline \multirow{2}{*}{\multicolumn{2}{|c|}{$\begin{array}{l}\mathrm{pH} \mathrm{CaCl} \\
\mathrm{P}^{-\mathrm{PO}_{4}}{ }^{-3}\left(\mathrm{mgkg}^{-1}\right)\end{array}$}} & $3,85 \pm 0,03 b$ & $3,85 \pm 0,05 b$ & $3,78 \pm 0,03 b$ & $4,51 \pm 0,11 a$ \\
\hline & & $3,22 \pm 0,44 b$ & $2,00 \pm 0,57 b$ & $1,45 \pm 0,34 c$ & $4,78 \pm 1,30 \mathrm{a}$ \\
\hline \multicolumn{2}{|c|}{$\mathrm{K}^{+}$} & $0,97 \pm 0,15 b$ & $0,54 \pm 0,08 c$ & $0,65 \pm 0,08 c$ & $3,33 \pm 0,23 a$ \\
\hline $\mathrm{Ca}^{++}$ & \multirow{2}{*}{ Top } & $1,44 \pm 0,47 a b$ & $1,22 \pm 0,29 b$ & $2,33 \pm 1,46 a b$ & $4,00 \pm 0,86 a$ \\
\hline $\mathrm{Mg}^{++}$ & & $1,00 \pm 0,22 b$ & $1,11 \pm 0,33+b$ & $1,22 \pm 0,44 b$ & $4,56 \pm 0,87 a$ \\
\hline $\mathrm{Al}^{3+}$ & \multirow{6}{*}{ 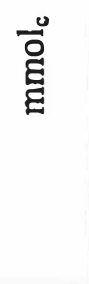 } & $29,78 \pm 0,91 \mathrm{ab}$ & $24,5 \pm 7,02 b$ & $36,22 \pm 1,45 a$ & $11,11 \pm 4,21 \mathrm{c}$ \\
\hline $\mathrm{H}^{+}$ & & $46,67 \pm 2,09 b$ & $30,61 \pm 8,39 c$ & $15,89 \pm 2,56 \mathrm{c}$ & $88,89 \pm 5,71 a$ \\
\hline SB & & $3,52 \pm 0,64 b$ & $2,77 \pm 0,33 b$ & $4,21 \pm 1,94 b$ & $11,89 \pm 1,59 \mathrm{a}$ \\
\hline $\mathrm{T}$ & & $79,97 \pm 2,06 b$ & $57,88 \pm 2,86 c$ & $56,32 \pm 3,01 \mathrm{c}$ & $111,89 \pm 5,42 \mathrm{a}$ \\
\hline$V(\%)$ & & $4,56 \pm 0,93 b$ & $4,78 \pm 0,71 b$ & $7,33 \pm 3,01 \mathrm{ab}$ & $10,56 \pm 1,43 a$ \\
\hline $\mathrm{m}(\%)$ & & $89,44 \pm 2,70 a$ & $89,78 \pm 5,38 a$ & $89,67 \pm 6,56 a$ & $44,78 \pm 20,50 b$ \\
\hline
\end{tabular}

*médias seguidas pela mesma letra, em cada linha, não diferem pelo teste de Tukey a $5 \%$ de probabididade.

Tabela 9. Concentração dos nutrientes nos cupinzeiros (totalidade) em relação a camada $0-15 \mathrm{~cm}$ do solo $(\mathrm{p}<0,05 ; \mathrm{n}=18)$

\begin{tabular}{cccccc}
\hline $\mathrm{P}-\mathrm{PO}_{4}^{-3}$ & $\mathrm{Ca}^{+2}$ & $\mathrm{Mg}^{+2}$ & $\mathrm{~K}^{+}$ & $\mathrm{SB}^{*}$ & $\mathrm{~V} \%$ \\
\hline 1,48 & 2,78 & 4,56 & 3,43 & 3,38 & 4,56 \\
\hline
\end{tabular}

*SB: soma de bases; V\%: saturação por bases.

Tabela 10 - Estoques de elementos no solo e nos cupinzeiros (totalidade).

\begin{tabular}{|c|c|c|c|c|c|}
\hline & \multicolumn{4}{|c|}{ Profundi dade $(\mathrm{cm})$} & \multirow[t]{2}{*}{ Cupinzeiros } \\
\hline & $0-15$ & $15-30$ & $30-50$ & $0-50$ & \\
\hline $\mathrm{P}-\mathrm{PO}_{4}^{-3}\left(\mathrm{~g} \mathrm{~m}^{-2}\right)$ & 0,54 & 0,42 & 0,41 & 1,37 & $8,5 \times 10^{-4}$ \\
\hline $\mathrm{K}^{+} \mathrm{T}$ & 163,68 & 112,63 & 184,9 & 461,21 & 0,59 \\
\hline $\mathrm{Ca}^{++} \mathrm{E}$ & 242,99 & 254,47 & 662,79 & 1160,25 & 0,71 \\
\hline $\mathrm{Mg}^{++}$ & 168,74 & 231,53 & 347,04 & 747,31 & 0,81 \\
\hline $\mathrm{Al}^{+3}$ & 5025,13 & 5110,25 & 10274,7 & 20410,07 & 1,98 \\
\hline $\mathrm{H}^{+}$ & 7890,36 & 6384,68 & 4520,07 & 18795,11 & 15,85 \\
\hline
\end{tabular}




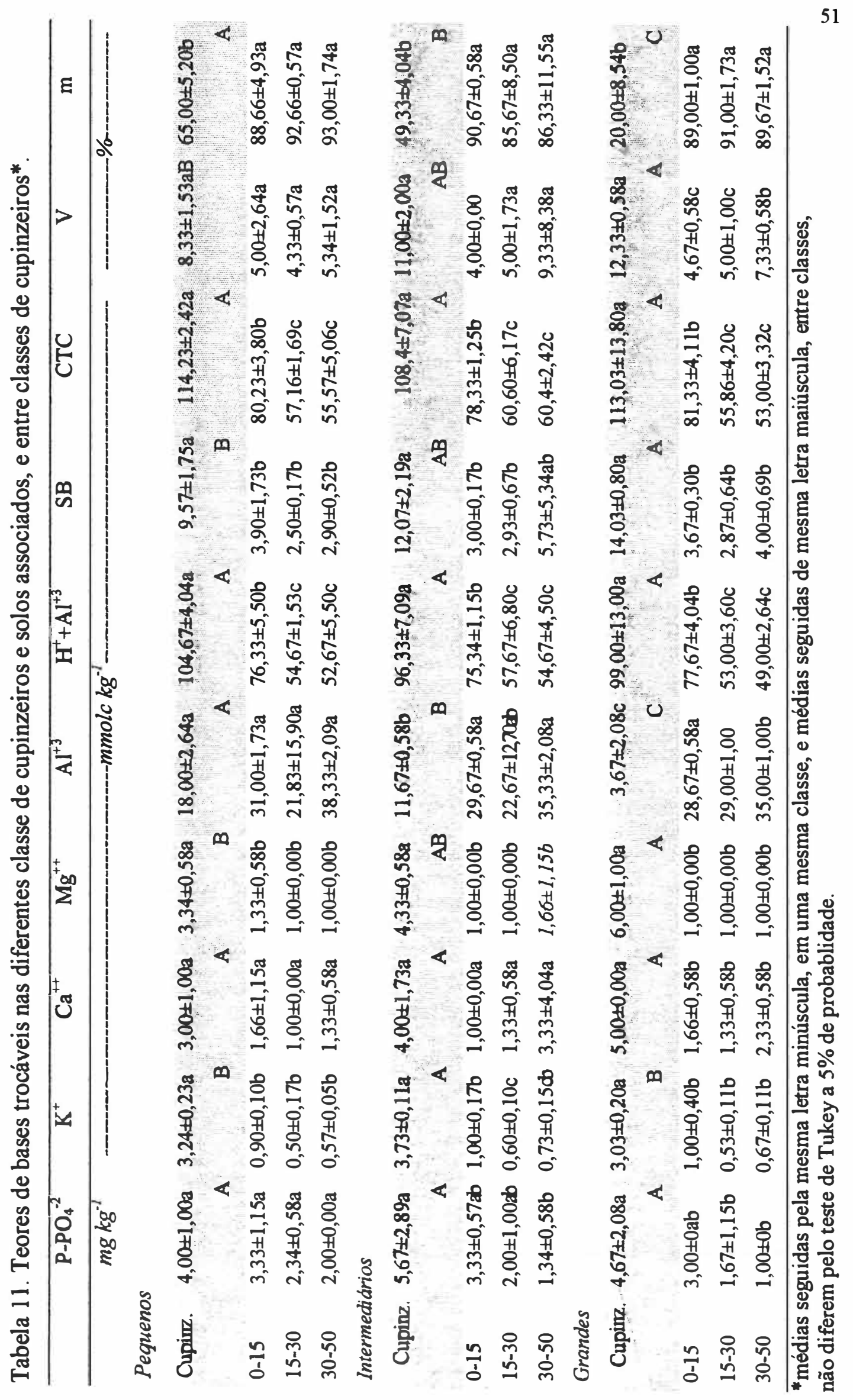


Tabela 12 - Balanço de elementos entre os cupinzeiros e o solo na profundidade 0-50 $\mathrm{cm}$.

\begin{tabular}{lcc}
\hline \multicolumn{2}{c}{ Cupinzeiros } & Solo 0-50 cm \\
& & $\%$ \\
\hline${\mathrm{P}-\mathrm{PO}_{4}^{--}}^{-{ }^{+}}$ & 0.062 & 99.938 \\
$\mathrm{~K}^{++}$ & 0.128 & 99.872 \\
$\mathrm{Ca}^{++}$ & 0.061 & 98.939 \\
$\mathrm{Mg}^{++}$ & 0.108 & 99.892 \\
$\mathrm{Al}^{+3}$ & 0.010 & 99.990 \\
$\mathrm{H}^{+}$ & 0.084 & 99.916 \\
\hline
\end{tabular}

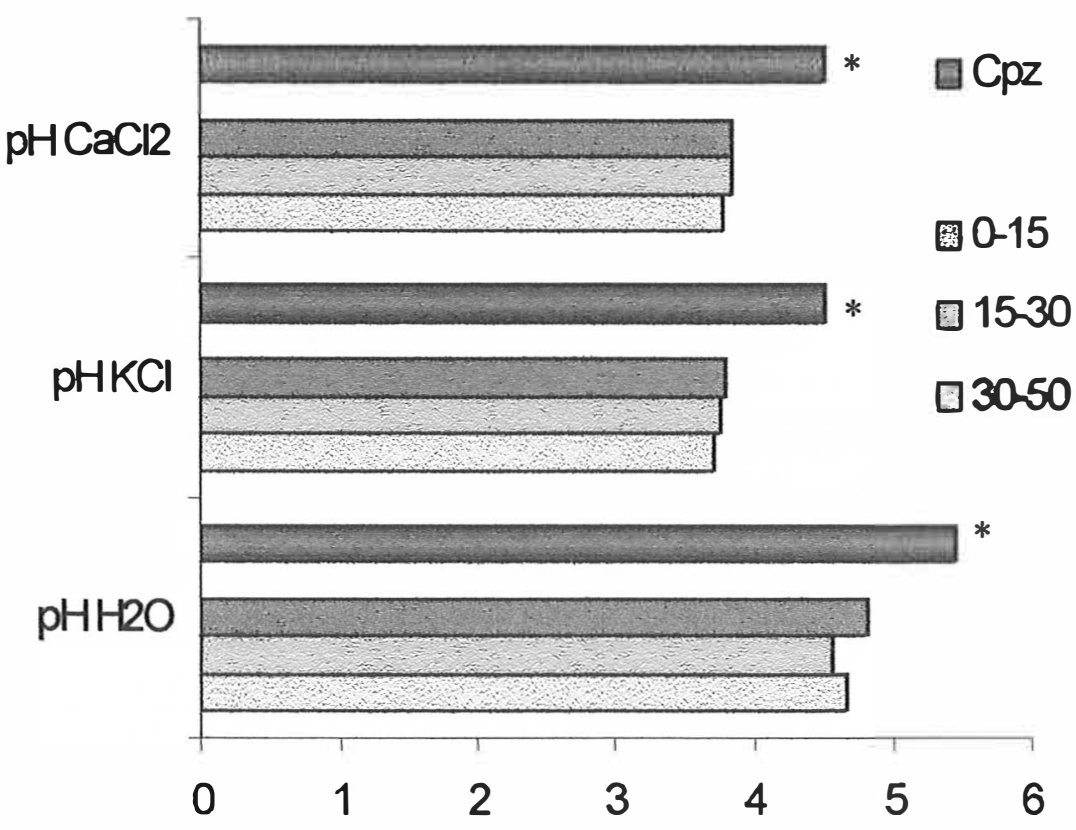

Figura $15-\mathrm{pH}, \mathrm{CaCl}_{2}, \mathrm{KCl}$ e $\mathrm{H}_{2} \mathrm{O}$ nos cupinzeiros e no solo.

* - singnificantemente superior nos cupinzeiros; 

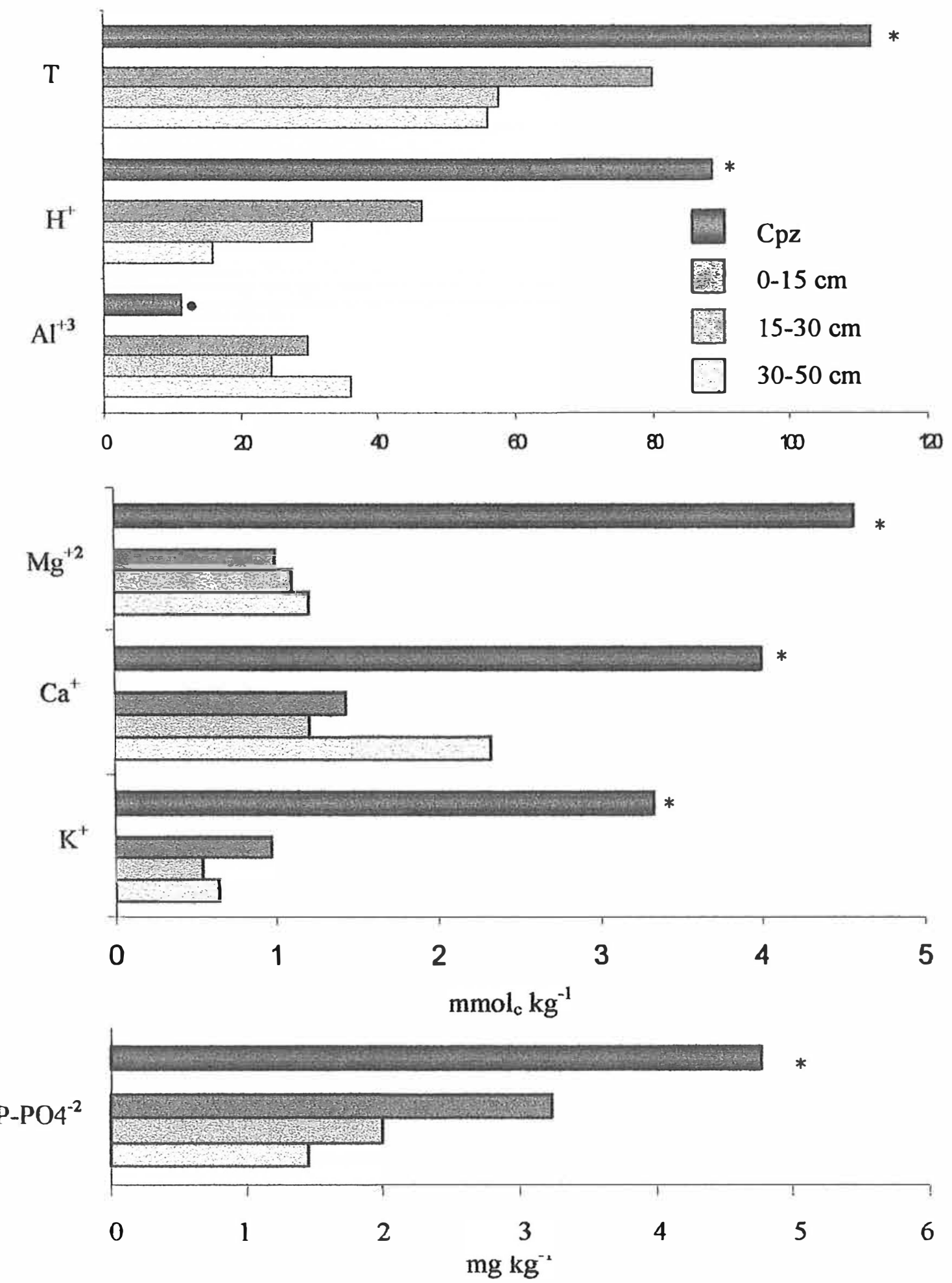

Figura 16 - Teores de bases trocáveis, CTC e $\mathrm{P}_{-} \mathrm{PO}_{4}{ }^{-2}$ nos cupinzeiros e no solo * - significantemente superior nos cupinzeiros;

- - significantemente inferior nos cupinzeiros. 


\subsubsection{Composição Quimica Total: Elementos Maiores e Traços}

A fim de realizar um balanço geoquímico dos elementos nos cupinzeiros e no solo, determinou-se a composição química total dos elementos maiores e elementos traços, obtendo-se os seguintes resultados:

\subsubsection{Elementos Maiores (Tabelas 13, 14 e 15, Figura 17)}

$\mathrm{SiO}_{2}$

A sílica é o elemento preponderante tanto nos solos como nos cupinzeiros (Tabela 13). Nos solos, varia de 773 a $786 \mathrm{~kg} \mathrm{~m}^{-2}$, não havendo diferenças significativas entre as camadas, a $\mathrm{p}<0,05$.

Nos cupinzeiros, corresponde a $675 \mathrm{~kg} \mathrm{~m}^{-2}$ dos teores totais, valor estatisticamente menor que todo o perfil analisado (Tabela 13, Figura 17). Entre as diferentes classes de cupinzeiros, "P" apresenta maior teor do elemento (690 $\left.\mathrm{kg} \mathrm{m}^{-2}\right)$, a $\mathrm{p}<0,05$ (Tabela 15).

Em relação ao estoque de silício, os cupinzeiros contribuem para apenas $0,12 \mathrm{~kg}$ $\mathrm{m}^{-2}$ (ou 1,2 ton ha ${ }^{-1}$ ), o que corresponde a $\mathbf{0 , 1 4} \mathrm{mm}$ da camada $0-15 \mathrm{~cm}$. Já os solos apresentam $51 \mathrm{~kg} \mathrm{~m}^{-2}$ (ou 510 ton ha ${ }^{-1}$ ) de $\mathrm{SiO}_{2}$ de 0 a $50 \mathrm{~cm}$ (Tabela 14).

$\mathrm{Al}_{2} \mathrm{O}_{3}$

É o segundo elemento em abundância, perfazendo 87 a $104 \mathrm{~kg} \mathrm{~m}^{-2}$ dos teores totais no solo. Apresenta aumento dos teores com a profundidade, a $p<0,05$ (Tabela 13).

Os teores nos cupinzeiros não diferem estatisticamente da camada $0-15$ cm (86 e $87 \mathrm{~kg} \mathrm{~m}^{-2}$, respectivamente), e são menores que a subsuperficie $(\mathrm{p}<0,05)$. Entre as classes de cupinzeiros, não há diferença entre médias (Tabela 15).

$\mathrm{O}$ estoque de $\mathrm{Al}_{2} \mathrm{O}_{3}$ nos cupinzeiros $\left(20 \mathrm{~g} \mathrm{~m}^{-2}\right.$, ou $\left.200 \mathrm{~kg} \mathrm{ha}^{-1}\right)$, é ínfimo quando comparado ao solo $\left(63 \mathrm{~kg} \mathrm{~m}^{-2}\right.$, ou 630 ton ha ${ }^{-1}$, de 0 a $\left.50 \mathrm{~cm}\right)$ e corresponde a 0,21 mm da camada 0-15 cm (Tabela 14). 
$\mathrm{Fe}_{2} \mathrm{O}_{3}$

Os teores no solo variam de 23 a $30 \mathrm{~kg} \mathrm{~m}^{-2}$, com tendência a aumento dos valores com a profundidade. $\mathrm{O}$ maior acúmulo se dá na camada $30-50 \mathrm{~cm}$, a p<0,05.

Nos cupinzeiros, os teores não diferem estatisticamente da camada 0-15 e 15-30 cm (Tabela 13). Entre as classes de cupinzeiros, não há diferença estatística entre as médias (Tabela 15).

Em relação ao estoque, os cupinzeiros contém $3,91 \mathrm{~g} \mathrm{~m}^{-2}$ (ou $39,1 \mathrm{~kg} \mathrm{ha}^{-1}$ ) de $\mathrm{Fe}_{2} \mathrm{O}_{3}$, o que equivale a $\mathbf{0 , 1 5} \mathrm{mm}$ da camada $0-15 \mathrm{~cm}$ do solo. Já o solo, de 0 a $50 \mathrm{~cm}$, compreende $17,8 \mathrm{~kg} \mathrm{~m}^{-2}$ (ou 178,5 ton $\mathrm{ha}^{-1}$ ) - (Tabela 14).

$\mathrm{TiO}_{2}$

No solo, varia de 1,6 a $1,8 \%$. A concentração aumenta com a profundidade, a $\mathrm{p}<0,05$.

Assim como o $\mathrm{Fe}_{2} \mathrm{O}_{3}$ e o $\mathrm{Al}_{2} \mathrm{O}_{3}$, os cupinzeiros apresentam os menores teores $(15 \%)$, diferindo, inclusive, da camada $0-15 \mathrm{~cm}$ do solo $(\mathrm{p}<0,05)$ (Tabela 13). As classes de cupinzeiros não diferem entre si a p<0,05 (Tabela 15).

Os cupinzeiros têm contribuição mínima para o a totalidade do elemento no solo $\left(2,68 \mathrm{~g} \mathrm{~m}^{-2}\right.$, ou $\left.26,8 \mathrm{~kg} \mathrm{ha}^{-1}\right)$, correspondendo a $\mathbf{0 , 1 5} \mathbf{m m}$ da camada $0-15 \mathrm{~cm}$ (Tabela 14).

$\mathrm{K}_{2} \mathrm{O}$

Os teores médios nos solos variam de 0,49 a 0,65\%, apresentando aumento da concentração com a profundidade, a $\mathrm{p}<0,05$.

A média dos cupinzeiros não difere da camada $0-15 \mathrm{~cm}, \mathrm{a} p<0,05$. As médias também não diferem entre as classes pré estabelecidas (Tabelas 13 e 15).

Os cupinzeiros estocam $849 \mathrm{mg} \mathrm{m}^{-2}$ de $\mathrm{K}_{2} \mathrm{O}$ (ou 8,49 $\mathrm{kg} \mathrm{ha}^{-1}$ ) - (Tabela 14), correspondente a $\mathbf{0 , 1 6} \mathrm{mm}$ da camada $0-15 \mathrm{~cm}$ do solo. 
$\mathrm{MgO}$

A camada 0-15 $\mathrm{cm}$ apresenta os menores teores $\left(1,5 \mathrm{~kg} \mathrm{~m}^{-2}\right)$, diferindo apenas de $30-50 \mathrm{~cm}\left(1,8 \mathrm{~kg} \mathrm{~m}^{-2}\right)$ a $\mathrm{p}<0,05$. Há tendência a aumento dos teores com a profundidade, com maior concentração na argila manchada $(30-50 \mathrm{~cm})$.

A média dos teores dos cupinzeiros $\left(1,6 \mathrm{~kg} \mathrm{~m}^{-2}\right)$ não difere estatisticamente de qualquer profundidade do solo. Também não se observa diferenças significativas entre as diferentes classes de cupinzeiros (Tabelas 13 e 15).

O estoque nos cupinzeiros compreende $288 \mathrm{mg} \mathrm{m}^{-2}$ (ou $2,9 \mathrm{~kg} \mathrm{ha}^{-1}$ ), que eqüivale a $0,17 \mathrm{~mm}$ da camada $0-15 \mathrm{~cm}$, enquanto que o solo $(0-50 \mathrm{~cm}), 1,10 \mathrm{~kg} \mathrm{~m}^{-2}$ (ou 11 ton. ha $\left.{ }^{-1}\right)$ - (Tabela 14).

$\mathrm{Na}_{2} \mathrm{O}$

No solo, os teores variam de 0,6 a $0,7 \mathrm{~kg} \mathrm{~m}^{-2}$, sem diferenças significativas entre as camadas do solo.

Os cupinzeiros não diferem do solo $(p<0,05)$, no entanto observa-se tendência a menor teor nos cupinzeiros $\left(0,58 \mathrm{~kg} \mathrm{~m}^{-2}\right)$. Entre as classes de cupinzeiros, as médias não diferem a $\mathrm{p}<0,05$ (Tabelas 13 e 15).

Quanto ao estoque, os cupinzeiros, em $1 \mathrm{~m}^{2}$, acumulam $103 \mathrm{mg}$ de $\mathrm{Na}_{2} \mathrm{O}$ (ou 1,03 $\mathrm{kg} \mathrm{ha}^{-1}$ ), o que equivale a $\mathbf{0 , 1 5 m m}$ da camada $0-15 \mathrm{~cm}$ do solo (Tabela 14).

$\mathrm{P}_{2} \mathrm{O}_{5}$

Os teores foram muito baixos para todas as camadas do solo e para os cupinzeiros $\left(0,5\right.$ a $\left.0,6 \mathrm{~kg} \mathrm{~m}^{-2}\right)$. Nos montículos, os valores não diferem estatisticamente do solo. As diferentes classes de cupinzeiros também são iguais, a p<0,05 (Tabelas 13 e 15).

O estoque de fósforo nos cupinzeiros é apenas de $116 \mathrm{mg} \mathrm{m}^{-2}$ (ou $1,16 \mathrm{~kg}$ $\mathrm{ha}^{-1}$ ), correspondente a $0,2 \mathrm{~mm}$ da camada $0-15 \mathrm{~cm}$. No solo, de 0 a $50 \mathrm{~cm}$, o estoque é $0,35 \mathrm{~kg} \mathrm{~m}^{-2}$ (ou 3,5 ton. ha ${ }^{-1}$ ) - (Tabela 14). 
$\mathrm{CaO}$

Os teores no solo são muito baixos, variando de 0,2 a $0,3 \mathrm{~kg} \mathrm{~m}^{-2}$, e não diferindo estatisticamente a $\mathrm{p}<0,05$.

Os cupinzeiros não diferem do solo a $\mathrm{p}<0,05$. No entanto, a comparação numérica (não estatística) indica que a média dos cupinzeiros é equivalente ao dobro dos valores encontrados nas diferentes camadas do solo (Tabela 13). A alta variabilidade dos dados (coeficiente de variação: 61,7\%) não permitiu a deteç̧ão estatística das diferenças entre médias.

Analisando-se os teores para as classes de cupinzeiros, observa-se que a maior variabilidade ocorre para a classe "P" (coeficiente de variação: $70,1 \%$ ). Já nos cupinzeiros grandes o coeficiente de variação é bem menor (13,9\%). A comparação do solo com os cupinzeiros indica, em " $\mathrm{G}$ ", acúmulo de $\mathrm{CaO}$ em relação ao solo, a p<0,05. "P" e "T" não apresentam diferenças significativas entre si, a p<0,05 (Tabela 15).

Apesar da maior concentração do elemento nos cupinzeiros, a contribuição para o estoque global é pequena $\left(83,7 \mathrm{mg} \mathrm{m}^{-2}\right.$, ou $\left.837 \mathrm{~g} \mathrm{ha}^{-1}\right)$ quando comparados com o solo $\left(170 \mathrm{~g} \mathrm{~m}^{-2}\right.$, ou 1,7 ton ha ${ }^{-1}$, de 0 a $50 \mathrm{~cm}$ ) - (Tabela 14). O estoque nos cupinzeiros equivale a $0,31 \mathrm{~mm}$ da camada $0-15 \mathrm{~cm}$ do solo.

$\mathrm{MnO}$

As concentrações no solo são inferiores em nível mínimo de deteç̧ão da análise realizada $(0,01 \%)$. Já os cupinzeiros possuem $0,08 \mathrm{~kg} \mathrm{~m}^{-2}$ do elemento (Tabela 13). Não há diferença significativa de médias entre as classes de cupinzeiros (Tabela $15)$.

Quanto ao estoque (Tabela 14), os cupinzeiros possuem apenas 14,2 mg $\mathrm{m}^{-2} \mathrm{de} \mathrm{MnO}$ (ou $142 \mathrm{~g} \mathrm{ha}^{-1}$ ).

Sintese dos Elementos Maiores

$\mathrm{O}$ elemento predominante nos solos e nos cupinzeiros é o $\mathrm{SiO}_{2}$. No entanto, observam-se menores teores de sílica nos cupinzeiros, em relação ao solo. $\mathrm{Al}$, 
$\mathrm{Fe}, \mathrm{Ti}, \mathrm{K}$ e $\mathrm{Mg}$ aumentam com a profundidade, e $\mathrm{Mn}$ é detectado apenas nos cupinzeiros, indicando concentração do mesmo nos montículos. Dentre os elementos que são nutrientes às plantas, o $\mathrm{K}$ apresenta os maiores teores nos solos e nos cupinzeiros. Atenção especial deve ser dada ao $\mathrm{Ca}$, que apresenta tendência a acúmulo nos cupinzeiros e tem extrema deficiência no solo. 

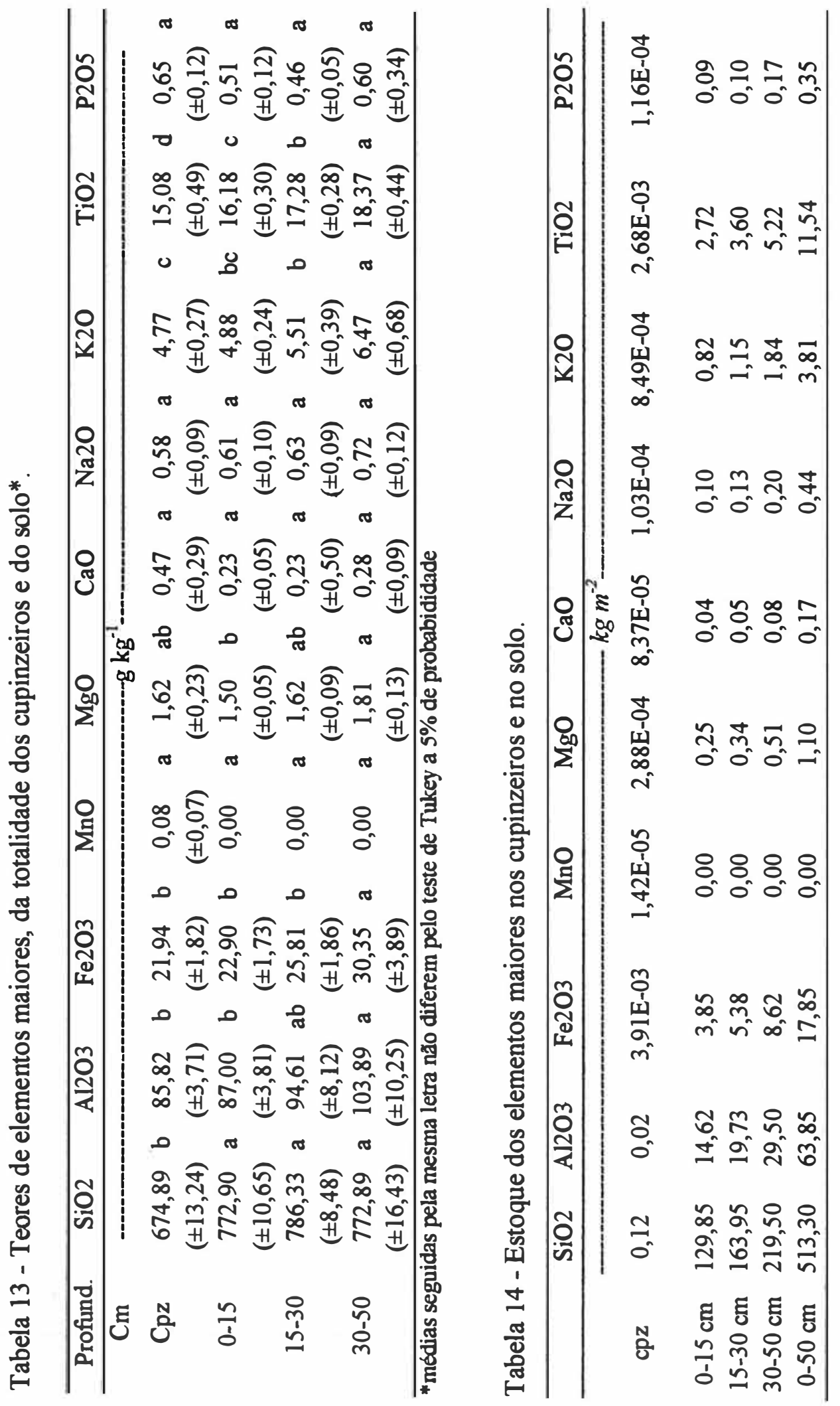


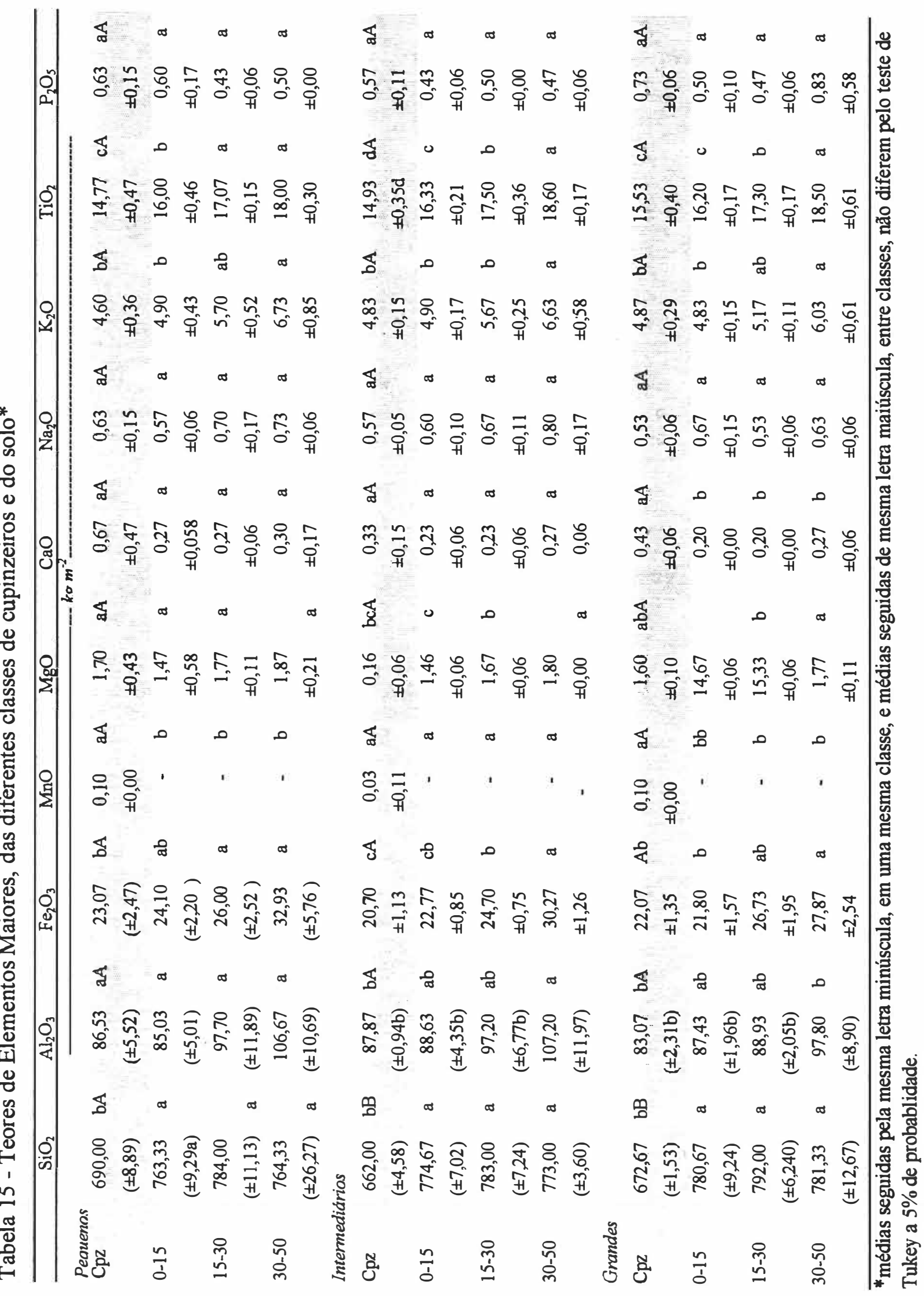



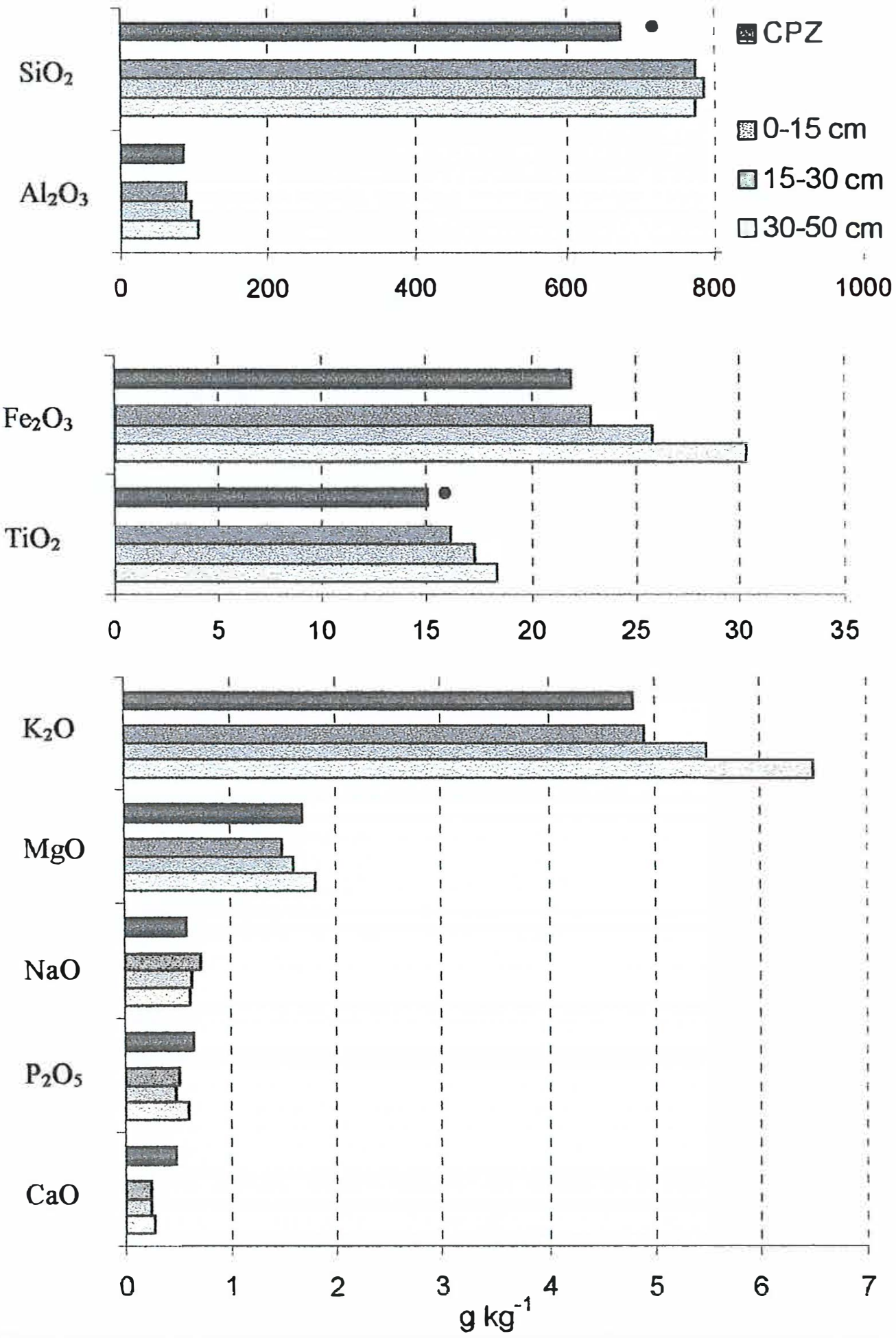

Figura 17 - Teores dos elementos maiores nos cupinzeiros e no solo - - significantemente menor nos cupinzeiros, em relação à camada 0-15 cm do solo. 


\subsubsection{Elementos Traços}

Os elementos traços compreendem os metais alcalinos, alcalinos terrosos, os metais dos grupos VA e VIA, os elementos de transição e as terras raras. Para estes, os seguintes teores foram encontrados:

Alcalinos e Alcalinos Terrosos: Bário (Ba), Estrôncio (Sr), Rubídio (Rb) e Césio (Cs) (Tabela 16)

No solo, os teores de Ba variam de 128 a $163 \mathrm{mg} \mathrm{kg}^{-1}$. Observa-se aumento progressivo dos teores com a profundidade, a $\mathrm{p}<0,05$. Nos cupinzeiros, a média dos teores é estatisticamente superior à camada $0-15 \mathrm{~cm}\left(145\right.$ e $128 \mathrm{mg} \mathrm{kg}{ }^{-1}$, respectivamente).

Para o $\mathrm{Sr}$, os teores médios no solo variam de 43 a $54 \mathrm{mg} \mathrm{kg}^{-1}$. Apresenta o mesmo tipo de distribuição que o $\mathrm{Ba}$, ou seja, aumento dos teores com a profundidade e média para os cupinzeiros superior ao da camada $0-15 \mathrm{~cm}$, a $\mathrm{p}<0,05$.

$\mathrm{O} \mathrm{Rb}$ no solo tem teores que variam de 37 a $47 \mathrm{mg} \mathrm{kg}^{-1}$. Os teores tendem a aumentar com a profundidade, todavia não se observa diferenças significativas entre as médias. Para os cupinzeiros, a média não difere da camada $0-15 \mathrm{~cm}$, a p<0,05.

$\mathrm{O}$ Cs varia de 4,0 a 4,6 mg kg-1 e tem o mesmo comportamento que o $\mathrm{Rb}$ no solo. Os cupinzeiros não diferem da camada 0-30 cm, a p<0,05.

Todos estes valores condizem com as médias mundiais para sedimentos argilosos, reunidas por Kabata-Pendias \& Pendias (1984).

Portanto, pode-se dividir os elementos alcalinos e alcalinos terrosos em 2 grupos: $\mathrm{Ba}+\mathrm{Sr}$ e $\mathrm{Rb}+\mathrm{Cs}$. Para os dois grupos, no solo, os teores aumentam em profundidade. Em relação à camada superior $(0-15 \mathrm{~cm}), \mathbf{B a}$ e $\mathbf{S r}$ têm maiores concentrações nos cupinzeiros (mais de $13 \%$ para $\mathrm{Ba}$ e mais de $7 \%$ para o $\mathrm{Sr}$ ). Por outro lado, $\mathrm{Rb}$ e Cs têm menores teores nos cupinzeiros (menos de 15\% para o Rb, e menos de $5 \%$ para o $\mathrm{Cs}$ ). 
Grupos VA e VI A: Chumbo (Pb), Arsênico (As), Bromo (Br) e Antimônio (Sb) - (Tabela 16)

Para o $\mathrm{Pb}$, os teores no solo estão em torno de $12 \mathrm{mg} \mathrm{kg}^{-1}$, com pequena tendência a aumento com a profundidade. Nos cupinzeiros, a tendência é de diluição do elemento $\left(9,2 \mathrm{mg} \mathrm{kg}^{-1}\right)$, apesar da diferença não ser significativa a $5 \%$.

Os teores de As e Sb, que no solo estão entre 3,7-6,0 e 0,9-1,1 mg kg-1, respectivamente. Aumentam com a profundidade, diferindo a $\mathrm{p}<0,05$ entre as diferentes camadas. Os teores de ambos, nos cupinzeiros, estão mais próximos aos valores da camada superficial, não diferindo entre si a p<0,05.

Os valores médios de $\mathrm{Br}$ no solo variam de 2,3 a 4,8 $\mathrm{mg} \mathrm{kg}^{-1}$. O elemento segue tendência contrária aos até aqui estudados. Nos solos, tem maior acúmulo na superfície, decrescendo em profundidade. Os maiores valores são encontrados nos cupinzeiros $(\mathrm{p}<0,05)$, com média $6,2 \mathrm{mg} \mathrm{kg}^{-1}$.

Elementos de Transição: Zircônio (Zr), Vanádio (V), Ítrio (Y), Cromo (Cr), Hafnio (Hf), Zinco $(\mathrm{Zn})$, Níquel (Ni), Escândio (Sc), Cobre $(\mathrm{Cu})$, Cobalto (Co), Tântalo (Ta), Tungstênio (W) e Au - (Tabela 18)

Deste grupo, o V, Y Cr, Hf, $\mathrm{Zn}$, Ni, Sc e o $\mathrm{Cu}$ aumentam com a profundidade, a $\mathrm{p}<0,05$. $\mathrm{Zr}$, $\mathrm{Co}$, $\mathrm{Ta}$ e $\mathrm{W}$ não tem variação significativa com a profundidade, apesar da tendência deste último em aumento da concentração em subsuperficie.

$\mathrm{O} \mathrm{Zn}$ e o $\mathrm{Cu}$ apresentam tendência a concentração nos cupinzeiros, quando comparados à camada $0-15 \mathrm{~cm}$ do solo.

Au apresenta comportamento atípico. Os teores nos cupinzeiros $(56,56 \mu \mathrm{g}$ $\left.\mathrm{kg}^{-1}\right)$ são maiores e diferem a $\mathrm{p}<0,05$, dos teores encontrados no solo $(22,44$ a $30,89 \mu \mathrm{g}$ $\mathrm{kg}^{-1}$ ). No solo, os teores não diferem a $\mathrm{p}<0,05$, no entanto observa-se tendência a decréscimo dos teores com a profundidade. Importante observar que os valores encontrados para Au estão acima da concentração média para sedimentos argilosos, que 
varia de 3 a $4 \mu \mathrm{g} \mathrm{kg}^{-1}$ (Kabata-Pendias \& Pendias, 1984). A média dos outros elementos correspondem à média para sedimentos argilosos, apresentados pelo mesmo autor.

Terras Raras Rantanídeos: Lantânio (La), Cério (Ce), Neodimio (Nd), Samário (Sm), Európio (Eu), Térbio (Tb), Itérbio (Yb), e Lutércio (Lu); Actinideos: Tório (Th) e Urânio (U) - (Tabela 20)

Para o grupo dos Lantanídeos, todos, com exceção do $\mathrm{Tb}$, apresentam maiores concentrações com o aumento da profundidade, a $\mathrm{p}<0,05$. Os teores de $\mathrm{Tb}$ não diferem a $\mathrm{p}<0,05$, porém, observa-se tendência a maior concentração com a profundidade.

Os cupinzeiros não diferem da camada $0-15 \mathrm{~cm}$ para estes elementos químicos, todavia observa-se para o $\mathrm{Nd}, \mathrm{Yb}, \mathrm{Sm}$ e Lu tendência a menores teores nos montículos.

Em relação ao grupo dos Actinídeos, os teores Th e U aumentam com a profundidade. Nos cupinzeiros, Th é menor em relação à camada $0-15 \mathrm{~cm}$. Já U não difere da mesma a $\mathrm{p}<0,05$.

Com exceção do $\mathrm{Yb}$, que tem concentração superior aos valores indicados por Kabata-Pendias \& Pendias (1984), os teores condizem com as médias mundiais para sedimentos argilosos.

Teores nas diferentes classes de cupinzeiros ("P", "I", $e$ " $G$ ")

Em relação às diferentes classes de cupinzeiros (Tabelas 22, 23 e 24), apenas o $\mathrm{Y}$ apresentou diferença a $\mathrm{p}<0,05$, sendo a maior média encontrada para a classe "G" (Tabela 23).

Para o Au, a comparação entre classes indica a tendência de maior acúmulo do elemento químico nos cupinzeiros pequenos. Nesta mesma classe, os cupinzeiros diferem do solo (maior concentração) a p<0,05. 
Estoque dos elementos traços

Os estoques dos elementos menores nos cupinzeiros são muito pequenos (Tabelas 17, 19 e 21), quando comparado ao solo. Eqüivalem de 0,11 a 0,21 mm da camada $0-15 \mathrm{~cm}$ do solo (exceto o $\mathrm{Au}$, que eqüivale a $0,29 \mathrm{~mm}$ da camada superficial do solo).

Síntese dos elementos traços

Os elementos que têm concentração nos cupinzeiros são o $\mathbf{B a}, \mathbf{S r}, \mathbf{B r}$ e Au. $\mathrm{Zn}$ e $\mathrm{Cu}$ possuem tendência a acúmulo nos cupinzeiros. Quanto ao solo, os elementos que aumentam com a profundidade são: $\mathrm{Sr}, \mathrm{Ba}, \mathrm{Rb}, \mathrm{Cs}, \mathrm{As}, \mathrm{Sb}, \mathrm{V}, \mathrm{Y}, \mathrm{Cr}, \mathrm{Hf}$, $\mathrm{Zn}, \mathrm{Ni}, \mathrm{Sc}, \mathrm{Cu}, \mathrm{La}, \mathrm{Ce}, \mathrm{Nd}, \mathrm{Sm}, \mathrm{Eu}, \mathrm{Yb}$ e Lu. Apesar do acúmulo de alguns elementos nos cupinzeiros, a contribuição para os estoques é muito pequena quando comparados ao solo. 


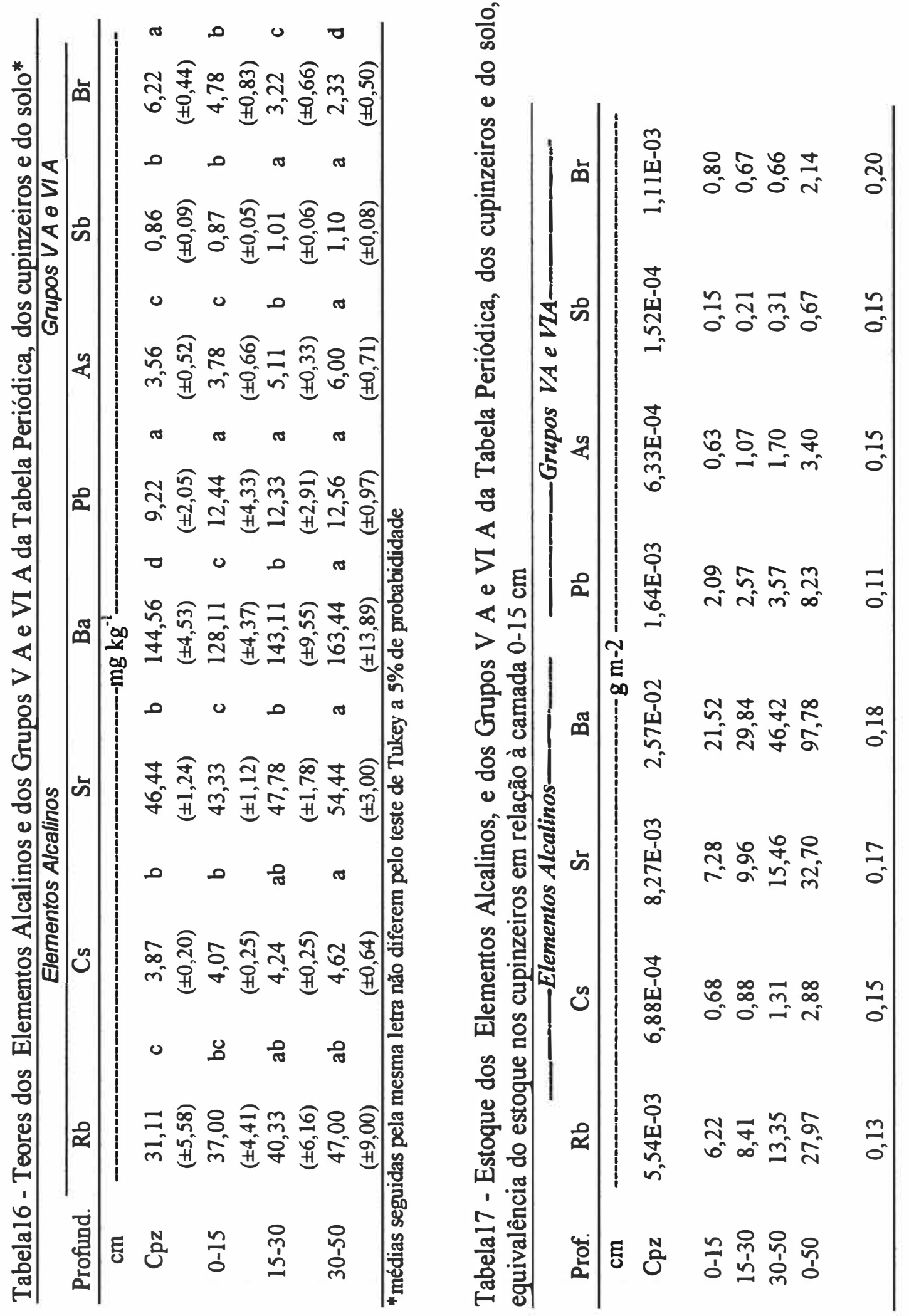




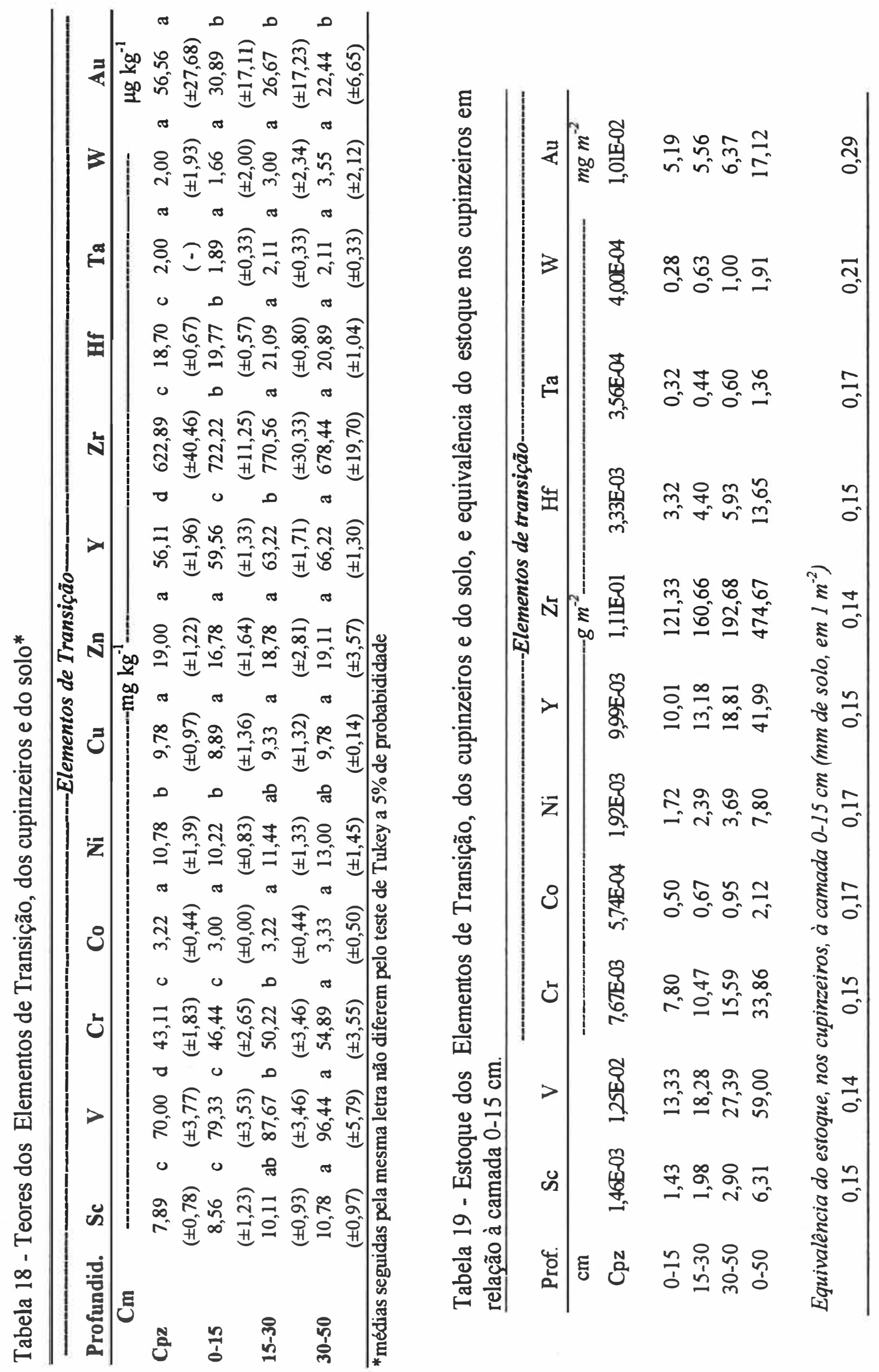



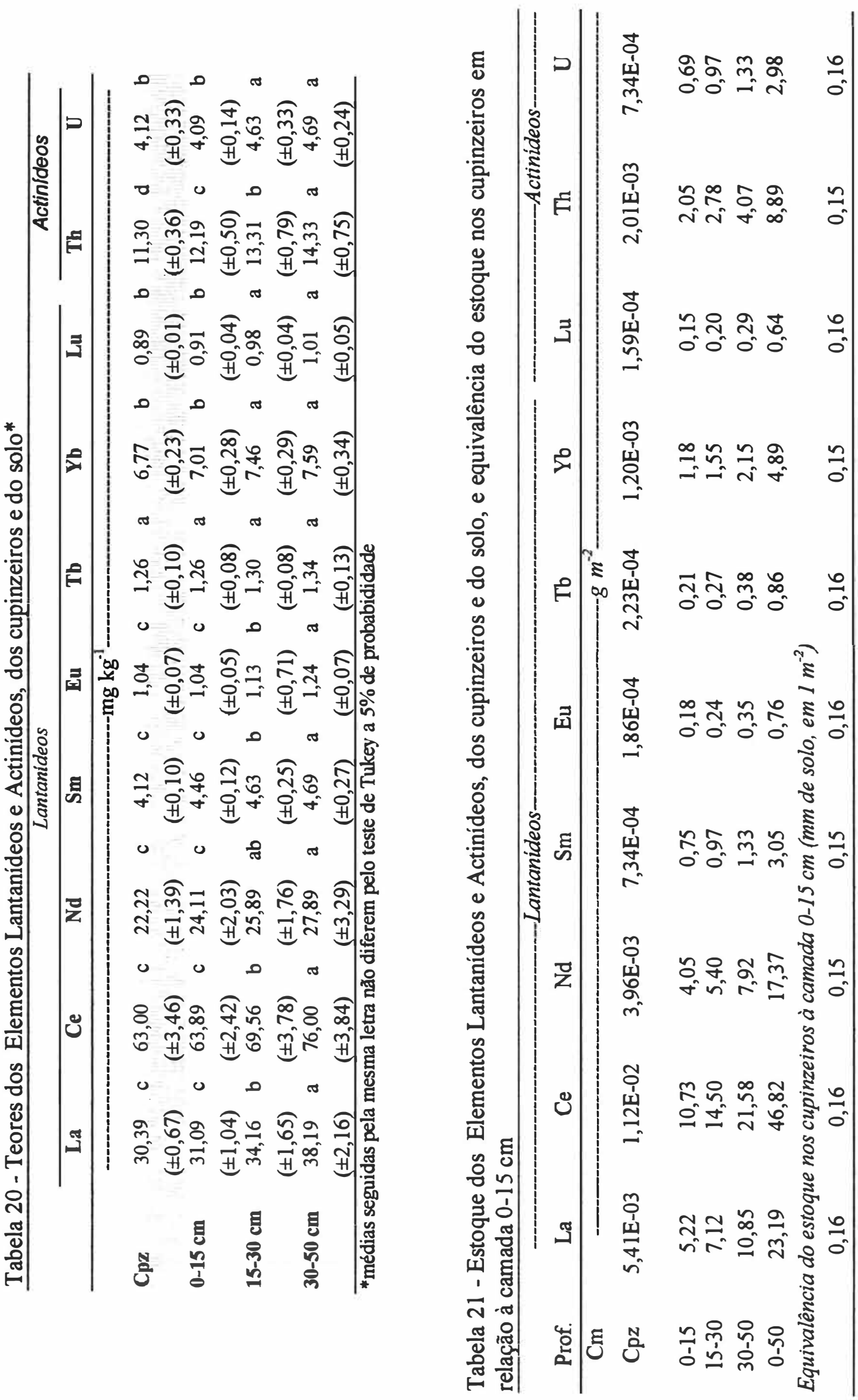


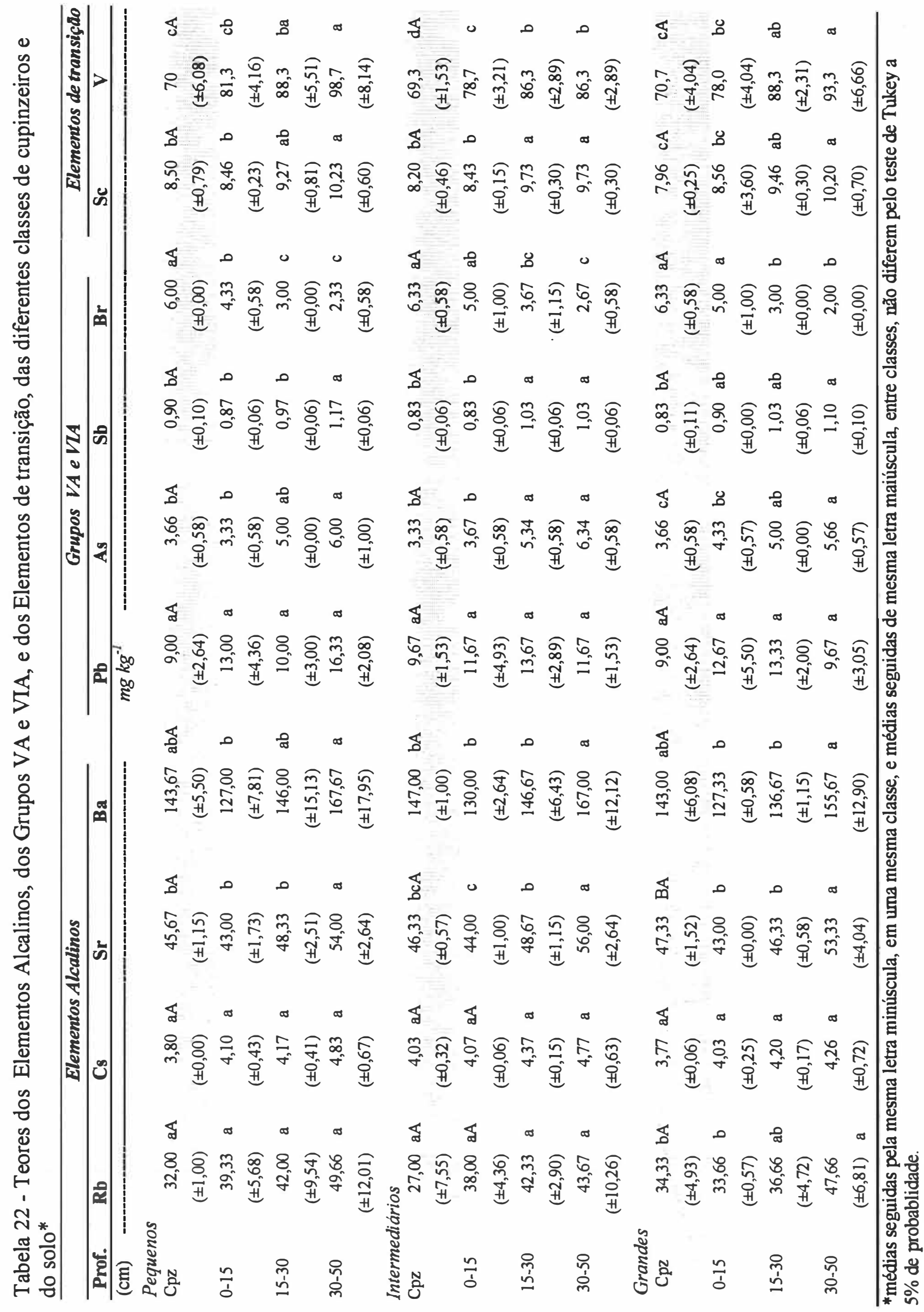




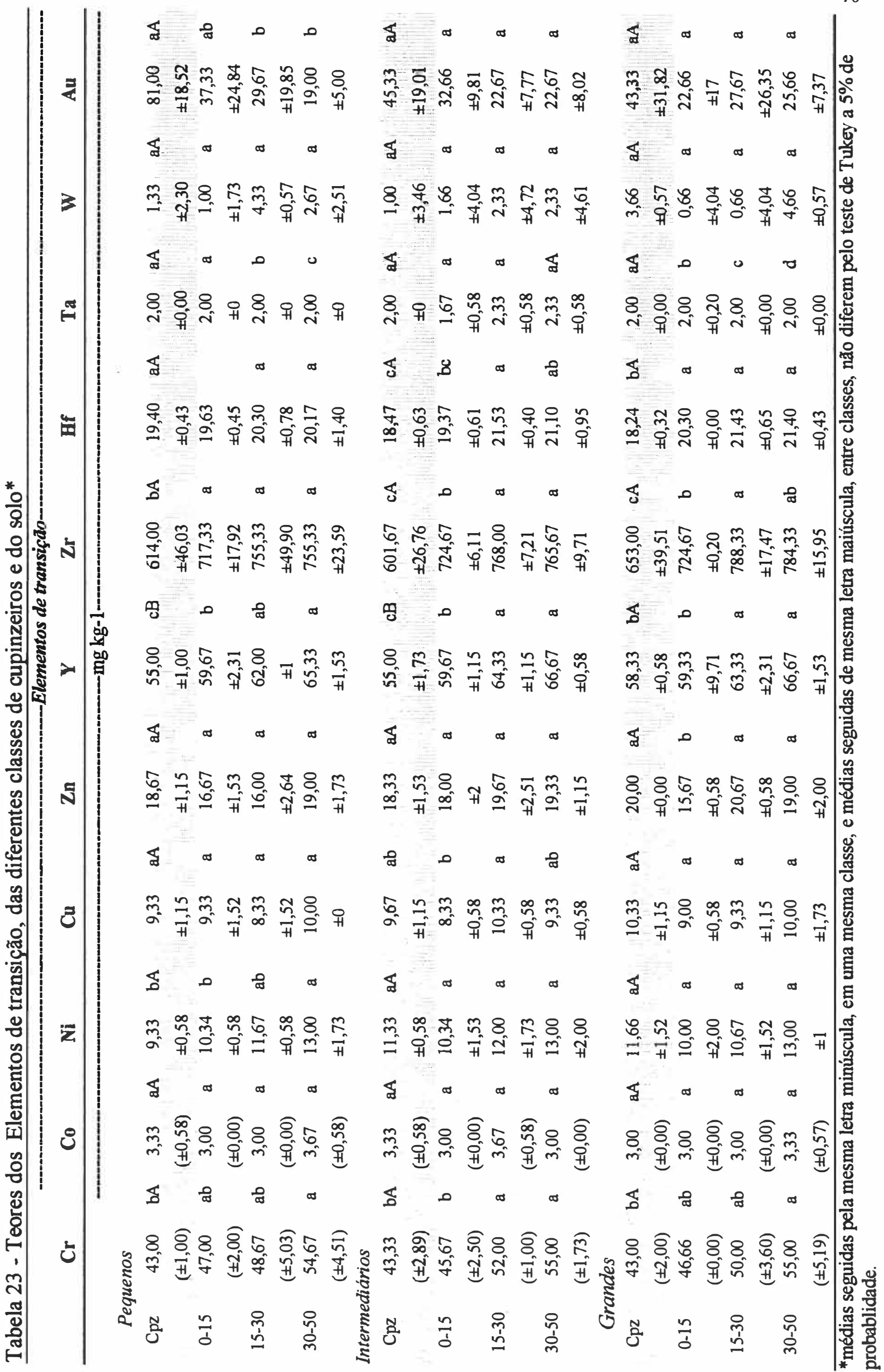




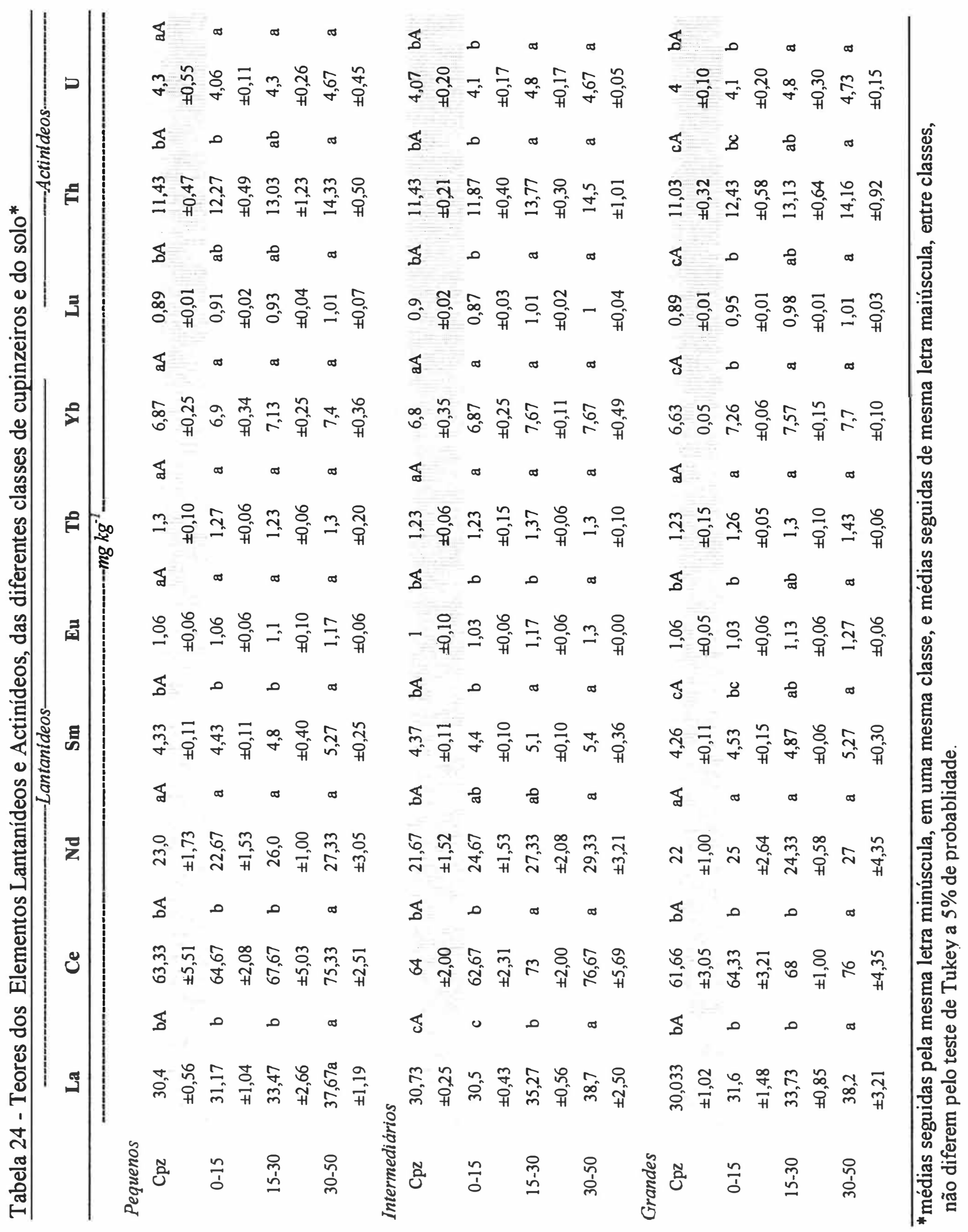


4.3.5 Estimativa dos teores dos principais constituintes mineralógicos do solo, a partir da composição quimica total

A partir dos teores totais de $\mathrm{SiO}_{2}, \mathrm{Al}_{2} \mathrm{O}_{3}$ e $\mathrm{K}_{2} \mathrm{O}$ estimou-se os teores dos principais constituintes minerais do solo. As expressões utilizadas para os cálculos foram:

$\%$ Muscovita $=\mathrm{K}_{2} \mathrm{O} \% \times 8,4564$

$\%$ Caulinita $=\mathrm{Al}_{2} \mathrm{O}_{3} \times 2,5316$

$\%$ Quartzo $=\mathrm{SiO}_{2 \text { total }}-\left(\mathrm{SiO}_{2 \text { Musc. }}+\mathrm{SiO}_{2}\right.$ Caul. $)$

Sendo:

Muscovita $=6 \mathrm{SiO}_{2}, 3 \mathrm{Al}_{2} \mathrm{O}_{3}, 2 \mathrm{H}_{2} \mathrm{O}, \mathrm{K}_{2} \mathrm{O}\left(\mathrm{SiO}_{2}=45,25 \%, \mathrm{Al}_{2} \mathrm{O}_{3}=38,39 \%\right)$;

Caulinita $=2 \mathrm{SiO}_{2}, \mathrm{Al}_{2} \mathrm{O}_{3}, 2 \mathrm{H}_{2} \mathrm{O}\left(\mathrm{SiO}_{2}=46,55 \%, \mathrm{Al}_{2} \mathrm{O}_{3}=39,50 \%\right)$;

Os resultados estão resumidos na Tabela 25.

Tabela 25. Estimativa da quantidade de muscovita, caulinita e quartzo nos cupinzeiros e nas diferentes profundidades do solo.

\begin{tabular}{cccc}
\hline & Muscovita & Caulinita & Quartzo \\
\cline { 2 - 4 } Cupinzeiro & 4,03 & 17,80 & 57,67 \\
$0-15 \mathrm{~cm}$ & 4,12 & 18,02 & 67,04 \\
$15-30 \mathrm{~cm}$ & 4,66 & 19,42 & 67,48 \\
$30-50 \mathrm{~cm}$ & 5,47 & 21,01 & 65,03 \\
\hline
\end{tabular}

Os valores para quartzo conferem com a análise granulométrica, quando comparados com os valores das frações areia + silte (compostas predominantemente por quartzo), e estimativa mineralógica para quartzo. Portanto, consiste num solo com predominância deste último, seguido de caulinita, e apenas uma pequena quantidade de muscovita. 


\section{DISCUSSÃO}

\subsection{Densidade dos cupinzeiros}

De acordo com Lee \& Wood (1971), a quantidade de cupinzeiros pode variar de menos de 1 a 1000 por hectare. Como os autores também consideram cupinzeiros inativos e de diferentes espécies, o valor observado para os cupinzeiros do gênero Armitermes na savana em estudo (608 por hectare) é semelhante à máxima (652 $\mathrm{ha}^{-1}$ ) indicada por Baroni-Ubani et al. (1978).

A área, portanto, é pertinente para o estudo da contribuição dos cupinzeiros para o estoque de elementos em um ecossistema. Deve-se observar que outras espécies de cupinzeiros ocorrem no local (principalmente do gênero Cornitermes), mas em menor quantidade que a espécie estudada. Sendo os valores dos estoques estimados apenas para um gênero de cupim, e não para a totalidade de cupinzeiros da área, estes são subestimados para a savana em estudo.

\subsection{Morfologia dos cupinzeiros e suas estruturas}

O estudo morfológico dos cupinzeiros assinala a contribuição da matéria orgânica para a composição dos montículos, dados suas cores cinza escuro e preto. $\mathbf{O}$ enriquecimento da fração mineral com matéria orgânica dá-se pela adição de saliva, ou de fezes, às unidades de construção.

A presença de pelotas, nos cupinzeiros, de cores similares às encontradas no horizonte plíntico, evidenciam a movimentação de material subsuperficial para a superficie, como veremos adiante. 


\subsection{Erodibilidade dos cupinzeiros}

Apesar de não se conhecer a longevidade dos cupinzeiros estudados, observou-se que são estruturas de relativa fragilidade, fato intensificado pelas condições climáticas do local (chuvas abundantes), e intensa predação por outros organismos (cupins de outras espécis e formigas). De fato, observa-se grande quantidade de material erodido dos cupinzeiros na superfície. Portanto, os cupinzeiros estão intimamente relacionados à dinâmica do solo, ao menos na camada superficial.

\subsection{Evolução do perfil do solo e a atividade biológica}

A evolução do perfil está intimamente relacionada à variação do lençol freático, que propicia condições de hidromorfismo, e conseqüente mobilização de materiais finos (caulinita e óxidos de ferro). Cores cinza e branca, que em profundidade dominam a matriz do solo, correspondem a sítios que sofreram redução e migração de ferro. Já os mosqueados vermelhos são as regiões de acúmulo e precipitação do ferro.

A organização da estrutura em blocos prismáticos é característica de solos sujeitos a variações de umidade e com presença de minerais expansíveis, como a vermiculita. A estrutura do solo também condiciona a porosidade fissural, predominante no horizonte pseudo-glei. Estes poros são os principais responsáveis pela movimentação da água no perfil, a partir de $14 / 18 \mathrm{~cm}$ até $30 / 40 \mathrm{~cm}$.

No entanto, a intensa atividade biológica em todo o perfil do solo, também contribui para a porosidade. Além de vazios formados por cupins de diferentes gêneros (Armitermes, Cornitermes e gêneros não identificados), câmaras de formigas do gênero Acromyrmex foram abundantes em todos os perfis analisados. Há também evidências de atividade de minhocas polihúmicas do gênero Megascolex, que possuem o hábito de escavar o solo até a superficie em busca de alimento. Além de escavar, estes mesmos organismos podem obstruir os vazios (pedotúbulos e granotúbulos). De qualquer forma, são ativos na transformação da porosidade do solo. 
Por ser um solo compacto, de drenagem deficiente, a presença de poros biológicos ainda contribui para a aeração e movimentação da água no perfil. (Nye, 1955; Tano \& Lepage, 1989; Mando et al., 1996). Além disso, facilitam a penetração e o desenvolvimento de raízes, por criar sítios ricos em nutrientes (paredes de estruturas com revestimento), e contribuem para a ciclagem de elementos, principalmente de carbono, no solo.

O hidromorfismo e a atividade biológica estão intimamente relacionados. Vazios de origem biológica revestidos por material orgânico são regiões propícias ao crescimento de organismos redutores do ferro. Durante o período em que o solo fica encharcado, microrrelevos na superficie do solo, geralmente cupinzeiros ativos ou inativos, são refúgios para a vegetação e para a fauna edáfica, pela melhor condição de aeração. Com o abaixamento do nível d'água, estabelece-se intensa atividade da fauna do solo, principalmente em superficie, mas também em subsuperficie.

O comportamento construtor dos cupins também pode ter relação com a oscilação do lençol freático. As galerias, além de conduzirem os cupins ao material utilizado nos montículos, é via de acesso à umidade. Pelas observações realizadas pôdese constatar que as galerias dos cupins alcançam ao menos 1 metro de profundidade. No entanto sabe-se que algumas espécies, em época de seca, buscam água a vários metros de profundidade (Lee \& Wood, 1971; Wood, 1988; Martins, 1993). Na área de estudo o nível d'água pode abaixar até 6 metros nos períodos de seca.

Foram observadas galerias sub-horizontais, localizadas na camada superficial do solo, logo abaixo dos cupinzeiros, e verticais, algumas atingindo ao menos até 1 metro de profundidade. Esta interferência ocorre inclusive no horizonte plíntico, onde fissuras macroscópicas são ausentes, e o solo apresenta regiões mais endurecidas. No entanto a maior concentração das galerias está na camada superficial, o que indica a preferência em buscar material do solo próximo as construções. Entretanto, galerias na argila manchada evidenciam a contribuição da subsuperficie nos montículos. 


\subsection{Deposições utilizadas nas estruturas}

As deposições utilizadas para a construção das diversas estruturas dos cupinzeiros são, em sua grande maioria, originadas da retirada de partículas pelas mandíbulas, enriquecimento com saliva, e posterior regurgitação. As cores das deposições encontradas (pretas, cinzas, brancas, brunas, vermelhas de diferentes tonalidades), indicam a origem do material utilizado para as construções dos cupinzeiros. O formato inicial é sub-esférico (Figura 34), variando de acordo com a pressão exercida com o hypofarynx dos operários de cupular a discóide.

Pelotas com cores características do horizonte pseudo-glei e plíntico (bruna, branco, cinza e vermelho), evidenciam a contribuição da subsuperficie para a formação dos montículos. Estas são em sua grande maioria discóides, devido a pressão exercida pelos operários. As pelotas coloridas ocorrem em menor quantidade, estão localizadas principalmente nos vértices das câmaras e em revestimento das galerias, bem aderidas às paredes. A localização das deposições sugerem que estas conferem maior resistência às estruturas.

As pelotas mais escuras podem ser oriundas da camada superficial do solo e/ou terem sofrido enriquecimento de matéria orgânica pelos cupins. Lee \& Wood (1971) observam que, em alguns casos, a pelota individualizada pelo aparelho bucal fica envolta por uma lâmina de excreta. Os operários retiram pedaços do solo, umedecem com a saliva, e depois excretam um fluído fino e preto no material individualizado. Desta forma, também enriquecem a fração mineral com material orgânico.

A observação de poucas pelotas cilíndricas, de origem fecal, sugere que estas, se não pouco utilizadas, são empregadas como material de cimentação. Mas é certo que as deposições escuras são elementos dominantes para todas as construções dos cupinzeiros, desde a zona epígea até revestimento de câmaras e galerias encontradas no solo. Sendo assim, o tamanho da população pode contribuir para a quantidade de pelotas fecais, e consequentemente para a concentração de matéria orgânica no cupinzeiro. Quanto maior a colônia, maior poderá ser a deposição de pelotas fecais. O fato é comprovado pela tendência a maior concentração de carbono nos montículos maiores. 
A única estrutura bem diferenciada da totalidade dos cupinzeiros refere-se ao conjunto de câmaras pretas, pertencente à câmara abandonada de Acromyrmex, posteriormente ocupada por cupins do gênero Armitermes. $\mathrm{O}$ aspecto de cartão, lenticular, e pouco resistente das paredes das câmaras indica origem fecal destas estruturas (Lee \& Wood, 1971). Estruturas deste tipo são encontradas na região central de alguns montículos, ou algumas vezes na totalidade deste. Em outras espécies, material similar é usado para revestir galerias dentro dos montículos, ou que servem de acesso a suprimento de alimento. No caso do conjunto de câmaras formado por cartão, observado a $44 \mathrm{~cm}$ da superfície, são provavelmente utilizadas como refúgio para os cupins.

\subsection{Granulometria}

As análises granulométricas da totalidade dos cupinzeiros indicam não haver seleção preferencial de partículas pelos cupins. Mas, apesar da argila total nos montículos não diferir estatisticamente da camada superficial do solo, as médias são superiores à camada $0-15 \mathrm{~cm}$ do solo, existindo portanto tendência a acúmulo de argila nos montículos. A maior concentração de argila é evidenciada nos montículos intermediários ('T’), diferentes da camada superficial do solo, a $\mathrm{p}<0,05$. A concentração de argila em cupinzeiros foi observada por Gamier-Sillam \& Harry (1995) e Bruyn \& Conacher (1995) em maior escala, no entanto em solos de granulometria mais grosseira. De fato, a significância das alterações físicas provocadas pelos cupins depende também da natureza do solo escavado (Wood \& Sands, 1978).

Sabe-se que a seleção de partículas se deve principalmente pelo tamanho do cibarium (regurgitação) ou pela geometria do intestino (excreção). As partículas carregadas desta forma são de fração argila, silte e algumas areias menores que $0,5 \mathrm{~mm}$ (limite superior para areia média) (Eschenbrenner, 1996). O fato do solo em estudo ser constituído principalmente por silte e argila e pequenas quantidades de areias médias, finas e muito finas, justifica a similaridade granulométrica entre os cupinzeiros e o solo. No entanto, além da tendência a acúmulo de argila, deve-se observar que são 
encontrados nos cupinzeiros uma pequena fração de areia grossa (1-0,5 mm). Partículas maiores que 0,5 mm (Wood \& Sands, 1978) até 3,0 mm (Eschenbrenner, 1996) são provavelmente transportadas pelas mandíbulas. Estruturas laminares, oriundas de excreta, não incluem esta fração.

\subsection{Argila dispersa em água e grau de floculação}

Comparando-se os diferentes horizontes, observam-se maiores valores de argila dispersa em água nos cupinzeiros, e na superfície do solo, respectivamente. Em subsuperficie a dispersibilidade dos colóides é menor. Os altos teores de $\mathrm{Al}$ trocável (89\%) podem estar favorecendo a floculação do solo em subsuperficie, uma vez que os tipos de estruturas em subsuperfície (prismática e maciça) são característicos de solos com elevada dispersibilidade de colóides, e, no entanto, observa-se 83 a $88 \%$ de floculação na camada $15-50 \mathrm{~cm}$ (Tabela 4). Outros fatores, como a composição mineralógica, o pH e a matéria orgânica também influem na floculação do solo (Seta \& Karathanasis, 1996)

A relação entre carbono orgânico e dispersibilidade dos colóides é dependente da natureza e teor da matéria orgânica. Desta forma, o material erodido oriundo dos cupinzeiros pode tanto estar contribuindo para o menor grau de floculação da camada superficial do solo, como para o aumento da dispersibilidade dos colóides. Substâncias orgânicas podem favorecer o processo de dispersão das partículas no solo (Oades, 1984). Maiores quantidades de frações húmicas de baixo peso molecular aumentam os valores da CTC total e da carga líquida negativa, reduzindo o grau de floculação do solo (Gomes, 1992). Por outro lado, presença de frações húmicas estáveis nos cupinzeiros possibilitam, quando no solo, maior estabilidade dos agregados. De acordo com Gamier-Sillan \& Harry (1995), espécies que enriquecem suas construções com matéria orgânica, especialmente ácidos húmicos estabilizados, contribuem com a conservação do solo. Para saber o processo dominante é necessário conhecer a natureza das frações orgânicas dos cupinzeiros, e também realizar estudos de estabilidade de agregados do solo. 
Independente da natureza da matéria orgânica, sabe-se que 1/4 da composição dos cupinzeiros é argilosa, com elevada dispersão em água. Este fato também explica a perda do material erodido, oriundo dos montículos, por erosão laminar. Outra forma de perda de argila em superficie seria a translocação de solutos e soluções por movimento subsuperficial de água (Buol et al., 1997). A não observação de argila iluviada em subsuperfície (lessivagem) descarta a hipótese de migração vertical de argila (Rosolen, com. pessoal). Predominam, portanto, os processos de perda de material fino (argiloso) em superficie, observados em campo.

\subsection{Mineralogia}

As observações mesoscópicas em lupa e através de raios - $\mathrm{X}$ indicam predominância de caulinita e quartzo, com pequenas quantidades de muscovita, vermiculita, mineral interestratificado mica-vermiculita e indícios de concreções de ferro e anatásio, nos cupinzeiros e solos associados.

Os cupinzeiros e solos associados apresentam mineralogia pouco variável, indicando a homogeneidade do material. Apesar da existência de nódulos vermelhos abaixo de $30 \mathrm{~cm}$ (matizes Munsell entre $5 \mathrm{YR}$ e 7,5 R), as análises mineralógicas mostraram apenas indícios de goethita e ausência de hematita. A ocorrência da cor vermelha é geralmente atribuída a estes minerais (matizes Munsell 2,5 YR e 7,5 YR, respectivamente) - (Eswaran \& Sys, 1970). No entanto, a determinação mineralógica do ferro pode ser dificultada pela pequena quantidade de Fe total (2 a 3\%), e pelo grau de cristalinidade de seus compostos (Brabant, s.d.). Óxidos e hidróxidos de ferro mal cristalizados, ou de tamanhos muito pequenos, podem estar revestindo os principais minerais constituintes do solo, atribuindo cor a estes.

Os cupinzeiros apresentam características mineralógicas similares ao solo, não havendo, portanto, indícios de neoformação mineral, como indicado por Boyer (1982).

Apesar da similaridade mineralógica, os picos da caulinita nos cupinzeiros apresentam maior intensidade do que os picos da camada $0-15 \mathrm{~cm}$ do solo. 
De fato, considerando que a caulinita está presente na fração argila do solo, os dados concordam com a tendência a acúmulo desta fração nos cupinzeiros. Também, a maior concentração de sílica total, de 0 a $15 \mathrm{~cm}$, em relação aos cupinzeiros (Tabela 13), sugere contribuição de grãos de quartzo para a fração argila, na camada superficial do solo, o que explicaria os menores picos encontrados nesta camada. A estimativa mineralógica indica apenas valores de caulinita similares aos cupinzeiros e a camada 0$15 \mathrm{~cm}$ do solo. Os resultados podem evidenciar seleção preferencial da fração argila nos cupinzeiros, mas também os processos erosivos que sofre a superficie do solo (erosão laminar).

Quanto a presença de micas e minerais interestratificados, estes irão explicar a maior ou menor ocorrência de alguns elementos químicos no solo, como veremos adiante.

\subsection{Fertlidade química dos cupinzeiros e solos associados}

\subsubsection{Carbono Orgânico}

Os cupinzeiros acumulam 3,3 vezes mais carbono $\left(76,2 \mathrm{~g} \mathrm{~kg}^{-1}\right)$ que a camada superficial do solo. Este acúmulo se dá principalmente nos montículos grandes $\left(81,5 \mathrm{~g} \mathrm{~kg}^{-1}\right)$, onde a colônia de cupins é maior, e pode contribuir mais intensamente para o aumento do $\mathrm{C}$ orgânico, com a utilização de saliva e fezes nas construções. Nos cupinzeiros pequenos, onde a colônia é pequena, o acúmulo de $\mathrm{C}$ foi menor $(69,6 \mathrm{~g} \mathrm{~kg}$ -

${ }^{1}$ ), constatando-se que é maior a quantidade de material utilizado que não passou pelo trato digestivo.

Com o acúmulo de matéria orgânica nos montículos, os cupins influenciam a distribuição e quantidade de matéria orgânica na savana em estudo. Este acúmulo envolve transferência de fertilidade do solo ao redor para os montículos, criando nichos favoráveis ao desenvolvimento de plantas. É importante notar que a matéria orgânica nos montículos pode representar somente uma fração (menos que metade) do total de matéria orgânica removida do ecossistema, sendo o restante 
metabolizado (Lee \& Wood, 1971). O gênero em estudo pode se alimentar, além de húmus do solo, de material vegetal vivo ou morto (Domingos, 1983), contribuindo portanto para a maior redistribuição da serrapilheira. (Jones, 1990).

A concentração de matéria orgânica pelos cupins nos montículos pode representar outra série de vantagens ao solo em estudo. A mistura de material mineral com o orgânico contribui para a conservação do $\mathrm{C}$ nos montículos, pois partículas de argila protegem o material orgânico contra mineralização (Garnier-Silan \& Harry., 1995; Koutika et al., 1999). Substâncias antimicrobianas produzidas pelos cupins também podem proteger a matéria orgânica da degradação (Rosengaus et al., 1998). Chen et al. (1998) encontrou naftaleno, substância repelente de artrópodos, helmintos e microorganismos, na saliva e excrementos de cupinzeiros subterrâneos. Além da proteção contra o ataque de microorganismos, os montículos são parcialmente resistentes ao fogo, comum em áreas de savana (observações de campo).

Portanto, os cupinzeiros em estudo, pela sua fragilidade em relação a outros tipos de montículos mais freqüentes no Brasil, podem ser um dos principais contribuintes à redistribuição e ciclagem de matéria orgânica no solo.

\section{$5.9 .2 p H$}

A atividade dos cupins do gênero Armitermes promove aumento do $\mathrm{pH}$, resultado discordantes de Bruyn \& Conacher. (1995). Os maiores valores se devem principalmente pelo acúmulo da matéria orgânica nas estruturas. $\mathrm{O}$ maior acúmulo de bases também contribui para os valores observados. $\mathrm{O}$ aumento do $\mathrm{pH}$ influencia a disponibilidade de alguns macronutrientes, contribuindo para o aumento da fertilidade local.

\subsection{3 $\mathrm{P}_{-} \mathrm{PO}_{4}^{-3}$ (resina)}

Os teores de fósforo são 1,48 vezes superior $\left(4,8 \mathrm{mg} \mathrm{kg}^{-1}\right)$ à camada $0-15$ cm. A concentração deste nutriente nos montículos é muito importante para o crescimento da vegetação, dada a sua escassez no solo $\left(3,2 \mathrm{mg} \mathrm{kg}^{-1}\right.$ na camada $\left.0-15 \mathrm{~cm}\right)$. 
São poucas as informações na literatura relacionando a atividade de cupins e a dinâmica do $\mathrm{P}$ no solo. No presente estudo, a maior concentração de $\mathrm{P}$ trocável nos cupinzeiros pode estar relacionada ao teor de matéria orgânica. No entanto, López-Hernández et al. (1989), estudando a atividade de cupins da espécie Nasutitermes ephratae em uma savana africana, observaram que, embora o C orgânico tenha sido significantemente maior nos cupinzeiros que nos solos associados, não houve aumento correspondente na atividade da fosfatase (enzima que promove a transformação do $\mathrm{P}$ orgânico em inorgânico), sugerindo que outros fatores além da matéria orgânica controlam a atividade da fosfatase nos montículos. Wood et al. (1983) atribuiram para cupins africanos do gênero Cubitermes que se alimentam de humus, a maior concentração de $\mathrm{P}$ ao efeito do elevado $\mathrm{pH}$ na parte anterior do intestino dos cupins. Sabe-se que, sob condições alcalinas, muitos complexos orgânicos e inorgânicos se dissociam, aumentando a disponibilidade do $\mathrm{P}$.

É evidente a importância dos cupins no ciclo do $\mathrm{P}$ em solos de baixa fertilidade natural. São necessários maiores estudos para avaliar os mecanismos de disponibilização do ânion, se por simples efeito de concentração, ou por redução local da adsorção.

\subsubsection{Bases trocóveis}

Os teores de cátions trocáveis são extremamente baixos no solo em estudo. Por outro lado, os cupinzeiros concentram até 4,5 vezes mais bases (no caso do $\mathrm{Mg}$ ) que a superficie do solo.

É clara a relação existente entre os teores trocáveis e a matéria orgânica concentrada nos cupinzeiros. A contribuição da matéria orgânica pode ser melhor compreendida observando-se as relações entre os teores trocáveis e os teores totais (Tabela 26). As relações mais significativas são encontradas nos cupinzeiros, que apresentam valores 2 a 3 vezes superiores a camada $0-15 \mathrm{~cm}$, mesma magnitude que a relação $\mathrm{C}$ cupinzeiro/C $0-15 \mathrm{~cm}\left(76,2 / 23,1 \mathrm{~g} \mathrm{~kg}^{-1}=3,3\right)$. Dentre as bases, $\mathrm{Ca}$ têm as maiores razões (17 a $24 \%$ dos teores totais), reforçando a hipótese de Sheikh \& Kayani 
(1982), de que grande quantidade de $\mathrm{Ca}$ e $\mathrm{Mg}$ se deve à presença destes elementos nas plantas que servem de alimento aos cupins. Ca é nutriente essencial à plantas, e praticamente ausente nos argilominerais do solo (Tabela 26). Sua disponibilidade está intimamente relacionada à dinâmica da matéria orgânica. A atividade dos cupins, é portanto essencial à concentração de disponibilidade do nutriente às plantas, neste solo.

Nos cupinzeiros, o K trocável também está intimamente relacionado com a matéria orgânica no solo. $\mathrm{O}$ cátion também está presente na muscovita, mas na forma não disponível. A contribuição dos argilominerais para os teores de $\mathrm{K}$ é refletida na menor relação $\mathrm{K}$ trocável/K total. A transferência de $\mathrm{K}$ da fração mineral a outra forma é muito lenta. O potássio é retido fortemente nas micas (Tisdale et al., 1993), em especial na muscovita, que são muito resistentes aos processos de intemperismo.

Portanto, dada a escassez de bases no solo, os cupinzeiros são extremamente importantes para a ciclagem e formação de nichos ricos em nutrientes às plantas. Além do crescimento mais vigoroso das gramíneas, observou-se maior germinação de arbustos próximos aos montículos, confirmando Jones (1990), ao observar o crescimento preferencial de plântulas em murunduns anteriormente ocupado por cupinzeiros. 
Tabela 26. Teores totais e trocáveis (troc.) do solo e dos cupinzeiros.

\begin{tabular}{|c|c|c|c|c|c|c|c|c|c|c|c|}
\hline & \multicolumn{3}{|l|}{$\mathrm{K}^{+}$} & \multicolumn{2}{|c|}{$\mathrm{Na}^{+}$} & \multicolumn{2}{|c|}{$\mathrm{Mg}^{+2}$} & \multicolumn{4}{|c|}{$\mathrm{Ca}^{+2}$} \\
\hline & $\begin{array}{l}\text { Tota } \\
l\end{array}$ & troc. & $\begin{array}{l}\text { troc./ } \\
\text { total }\end{array}$ & total & Troc. & total & troc. & $\begin{array}{l}\text { troc. } \\
\text { total }\end{array}$ & total & troc. & $\begin{array}{l}\text { troc. } \\
\text { total }\end{array}$ \\
\hline & & & & & & $m m c$ & $\mathrm{~kg}^{-1}$ & & & & - \\
\hline Cpz & 101,3 & 3,33 & $3,3 \%$ & 18,7 & - & 80,4 & 4,56 & $5,7 \%$ & 16,8 & 4,00 & $23,8 \%$ \\
\hline $0-15 \mathrm{~cm}$ & 103,6 & 0,97 & $0,9 \%$ & 19,7 & - & 74,4 & 1,00 & $1,3 \%$ & 8,2 & 1,44 & $17,56 \%$ \\
\hline $15-30 \mathrm{~cm}$ & 117,0 & 0,54 & $0,5 \%$ & 20,3 & - & 80,4 & 1,11 & $1,4 \%$ & 8,2 & 1,22 & $14,9 \%$ \\
\hline $30-50 \mathrm{~cm}$ & 137,4 & 0,65 & $0,5 \%$ & 23,2 & - & 89,8 & 1,22 & $1,3 \%$ & 10,0 & 2,33 & $23,3 \%$ \\
\hline
\end{tabular}

\subsection{5 $A I^{+3}$ tracável}

A média dos teores de $\mathrm{Al}$ trocável nos cupinzeiros é 3 vezes inferior ao da camada 0-15 cm do solo. Os valores observados estão relacionados ao teor de carbono, e ao $\mathrm{pH}$ dos montículos. Sabe-se que a atividade do $\mathrm{Al}$ no solo é dependente do $\mathrm{pH}$, diminuindo 1000 vezes para cada 1 unidade a mais de pH (Tomé Jr., 1997). O aumento do $\mathrm{C}$ orgânico também pode ocasionar redução da quantidade de Al trocável (Pavan, 1983). Santos (1997) atribui esta diminuição à neutralização do Al por mecanismos de complexação organometálica. Outro processo, refere-se à adsorção de $\mathrm{H}$ e $\mathrm{Al}$ nas moléculas orgânicas.

\subsection{Ocorrência dos Elementos Maiores e Traços nos Cupinzeiros e nos Solos Associados}

Da mesma forma que os elementos maiores, os teores dos elementos traços estão relacionados à fração mineral do solo, a granulometria, ao grau de mobilidade destes elementos químicos, e também, em alguns casos à matéria orgânica. A afinidade destes elementos aos diversos componentes do solo irão determinar a concentração nos cupinzeiros e nos solos associados. 


\subsubsection{Elementos maiores}

Os cupinzeiros, e o solo em estudo, têm como elementos predominantes o silício, seguido de alumínio e pequena quantidade de ferro. Outros elementos pouco abundantes são o $\mathrm{TiO}_{2}, \mathrm{~K}_{2} \mathrm{O}, \mathrm{MgO}, \mathrm{CaO}, \mathrm{Na}_{2} \mathrm{O}$ e $\mathrm{P}_{2} \mathrm{O}_{5}$, sendo $\mathrm{MnO}$ não detectado no solo (Figura 17).

Os montículos apresentam maior concentração apenas do $\mathrm{MnO}$, e tendência a acúmulo de $\mathrm{CaO}$ (acúmulo nos cupinzeiros grandes), em relação ao perfil do solo. Outros elementos nos montículos têm teores similares aos da camada superficial do solo.

A utilização pelos cupins de material orgânico e partículas finas (argilosas), em adição ao material mineral, é evidenciado pelo menor teor de sílica em suas estruturas, quando comparados à subsuperficie do solo. A similaridade dos valores à camada $0-15 \mathrm{~cm}$ pode ser devida a contribuição da superficie para a construção das estruturas, e/ou a contribuição dos montículos para a superficie do solo.

Os teores totais de $\mathrm{CaO}$ nos cupinzeiros têm grande contribuição dos teores trocáveis, enriquecidos nos cupinzeiros pelo acúmulo de matéria orgânica $(23,8 \%)$ - (Tabela 26). Para MnO pode estar ocorrendo a mesma influência da matéria orgânica.

De uma forma geral, as maiores concentrações de elementos maiores são encontradas na subsuperfície do solo, exceção feita para o $\mathrm{SiO}_{2}$, como já explicado anteriormente. As concetrações estão relacionadas à associações destes elementos com os minerais do solo, a granulometria e a mobilidade destes elementos químicos.

Em relação a mineralogia, a predominância de sílica está relacionada a abundância de quartzo, e sua presença nos argilominerais. O alumínio também faz parte da composição de minerais de argila, podendo também estar presente como gibsita, apesar da forma cristalina não ter sido detectada pela difratometria de raios - X. Já o $\mathrm{Fe}$ pode estar presente na forma livre, amorfa, como microcristais, ou como componentes de argilominerais, uma vez que que óxidos de ferro cristalinos são ocasionais no solo e nos cupinzeiros. 
O acúmulo do ferro em subsuperfície está relacionado a movimentação do lençol freático ao longo do perfil, e aos processos de hidromorfismo do solo. Estabelecidas as condições de redução do $\mathrm{Fe}$, este passa para a forma solúvel, e é translocado ao longo do perfil. Em condições físico químicas favoráveis o ferro precipita e acumula, principalmente nos poros de natureza diversa (Brabant, 1988). É possível também a movimentação ascendente do Fe presente no horizonte $\mathrm{C}$ e $\mathrm{R}$ (Rosolen, com. pessoal), também pela elevação do nível d'água.

O titânio também está associado à argila manchada. É um elemento estável, residual, geralmente presente no solo sob a forma de anatásio, mineral muito resistente à ação do intemperismo (Hutton \& Osmond, 1987).

Potássio está presente em micas (muscovita) e minerais interestratificados 2:1. O intemperismo destes minerais possibilita a liberação de $\mathrm{K}$ para a solução do solo, podendo ser desta forma lixiviado. Portanto, nos horizontes que sofreram maior ação do intemperismo, havendo maior disponibilização do elemento à solução, observam-se menores teores totais do elemento. Em subsuperficie, onde o material está menos alterado, a maior parte do $\mathrm{K}$ presente no solo ainda está preso entre as lamelas de micas e argilominerais $2: 1$.

A ocorrência de $\mathrm{Mg}$ explica-se pela associação do elemento químico à vermiculita, que o possui como parte constituinte de sua estrutura.

\subsubsection{Elementos Traços}

Os cupinzeiros apresentaram maior concentração de bário, estrôncio, bromo e ouro. Estes elementos estão relacionados a compostos orgânicos (Dixon, 1987), sendo encontrados com maior freqüência na camada rica em húmus (Kabata-Pendias \& Pendias, 1984). No entanto, o Au tem maior concentração nos montículos pequenos, onde é menor o acúmulo de matéria orgânica. Este elemento pode também estar sendo concentrado na forma particulada nos cupinzeiros. Watson (1972) observou maior concentração de Au nos montículos e na superfície do solo associado, e concluiu que os cupins transportam o elemento para suas estruturas, oriundo de depósitos de ao menos 3 
metros de profundidade. No entanto, para a área de estudo esta hipótese é vaga, pois é desconhecida a concentração de ouro em profundidade.

Em relação ao solo, são vários os elementos que aumentam com a profundidade: $\mathrm{Sr}, \mathrm{Ba} \mathrm{Rb}, \mathrm{Cs}, \mathrm{As}, \mathrm{Sb}, \mathrm{V}, \mathrm{Cr}, \mathrm{Hf}, \mathrm{Zn}, \mathrm{Ni}, \mathrm{Sc}, \mathrm{Cu}, \mathrm{La}, \mathrm{Ce}, \mathrm{Nd}, \mathrm{Sm}, \mathrm{Eu}, \mathrm{Yb}$ e Lu. Muitos destes elementos foram detectados por microanálise, em cristais de goetita presentes em nódulos da camada $30-50 \mathrm{~cm}$ do solo (Figura 41B).

$\mathrm{O} \mathrm{Ba}$ pode também estar associado ao $\mathrm{K}^{+}$, devido ao raio iônico similar, e por ser fortemente adsorvido por argilas (Kabata-Pendias \& Pendias, 1984).

Sr tem fácil mobilidade, especialmente em meios oxidantes ácidos, sendo altamente lixiviado para a base do perfil, incorporados em minerais de argila e óxidos e hidróxidos de Fe (Dixon, 1987).

$\mathrm{O}$ acúmulo de $\mathrm{Rb}$ e o Cs em subsuperficie explica-se pela afinidade destes com micas e minerais expansíveis $2: 1$, tendo estes últimos alta afinidade por muitos cátions monovalentes, (Kabata-Pendias \& Pendias, 1984).

$\mathrm{Zr}$ e Hf ocorrem em minerais que são muito resistentes ao intemperismo (Hutton \& Osmond, 1987), seguindo a tendência, portanto, do Ti. Já o Th e o U são facilmente mobilizados na forma de cátions complexados ionicamente e organicamente, sendo que as frações argila têm grande afinidade em adsorver estes elementos.

Os lantanídeos são enriquecidos nas estruturas dos minerais de argila, e aos sítios de adsorção (Balashov \& Girin, 1969).

\subsection{Por que os estoques são baixos?}

Apesar da alta concentração de cupinzeiros no local, e concentração de alguns elementos em suas estruturas, podemos relacionar alguns fatores que determinam os baixos estoques:

a. Densidade aparente dos cupinzeiros - a densidade aparente das estruturas é baixa $\left(0,74 \mathrm{~g} \mathrm{~cm}^{-3}\right)$ em relação ao solo. A baixa densidade é atribuída à sua morfologia interna, repleta de câmaras. 
b. Volume considerado para o solo e para os cupinzeiros - para a estimativa dos estoques, os cálculos foram realizados considerando as amostras de solo cilíndricas, e dos cupinzeiros cônicos. Para o mesmo raio e altura, um cilindro apresenta volume 3 vezes superior a um cone (volume cilindro $=\pi r^{2} h$; volume cone $=1 / 3 \pi r^{2}$ h). Desta forma, com maior volume e maior densidade aparente, a quantidade de terra considerada é maior, tendo como conseqüência maior estoque de elementos no solo.

Nestes aspectos, quando consideramos a contribuição local dos estoques dos cupinzeiros e do solo em uma mesma área (no caso, relativo ao perímetro do cupinzeiro), observa-se que a contribuição de ambos é da mesma ordem de grandeza (Figura 18).

c. Área coberta pelos cupinzeiros - apesar de ser alta, representa apenas $0,21 \%$ da área total. É o principal fator determinante do baixo estoque de elementos nos montículos.

Pelos fatores supracitados, a contribuição para o estoque de elementos é localizada, e a grande importância dos montículos está, portanto, na ciclagem de elementos e não no seu estoque. 


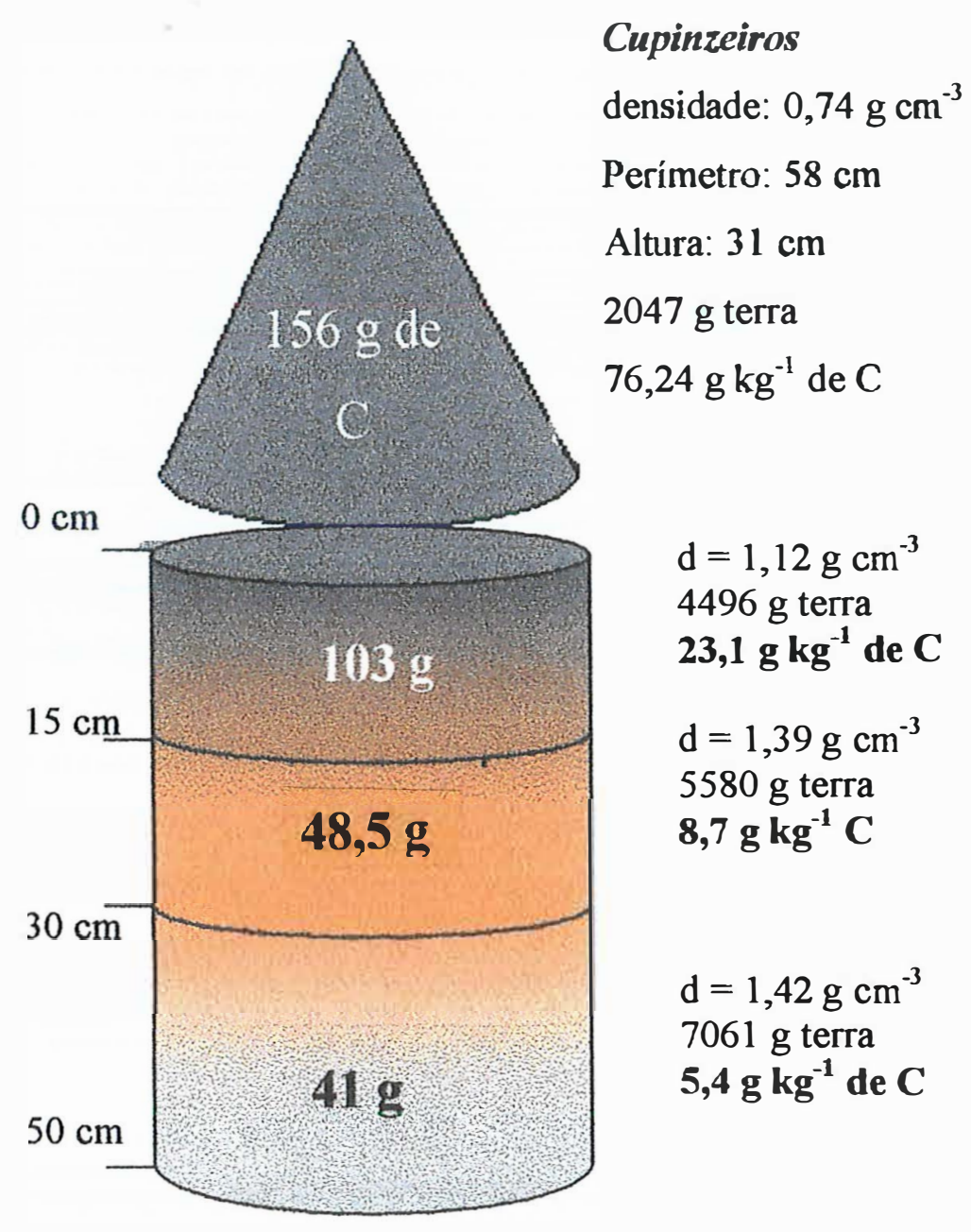

Figura 18 - Estoque local de $\mathrm{C}$ nos cupinzeiros e no solo associados 


\subsection{Cupins e ciclagem de elementos no solo}

Os cupins atuam de diversas formas nos ciclos biogeoquímicos do solo. Diretamente, operam no transporte e ingestão de material orgânico e partículas minerais, que são concentradas em suas estruturas, e posteriormente liberadas ao solo com a erosão parcial ou total dos montículos. Indiretamente, afetam a microbiota do solo em vários níveis. $\mathrm{O}$ material ingerido, mais facilmente metabolizado pelos cupins, uma vez liberado ao solo e sem a ação dos produtos antimicrobianos é facilmente assimilado pela microbiota de vida livre, que mineraliza mais rapidamente a matéria orgânica. Ainda, a mobilidade limitada dos microorganismos é compensada pelo trânsito de animais de elevada mobilidade, como os cupins e as minhocas, que podem dispersar os microorganismos presentes na superfície do corpo, ou no conteúdo intestinal. A dispersão, ativação e movimentação da microflora é melhor elucidado para as minhocas (Lavelle et al., 1992; Barois \& Lavelle, 1986; Brown, 1995), mas pouco discutido para os cupins.

Além do efeito sobre a microbiota, a intensa atividade de outros organismos, como as minhocas, formigas, besouros e outros, evidencia a relação dos cupinzeiros com componentes da pedofauna. Eles são atraídos pelo acúmulo da matéria orgânica no montículo e contribuem para a homogeneização da camada superfícial, por ingerir partículas da superfície e liberar seus dejetos em subsuperficie.

Estabelece-se, portanto, complexa interação dos cupins do gênero Armitermes com fatores bióticos e abióticos do solo (Figura 19). A compreensão destes mecanismos contribui para a elucidação da dinâmica atual do solo em estudo. 


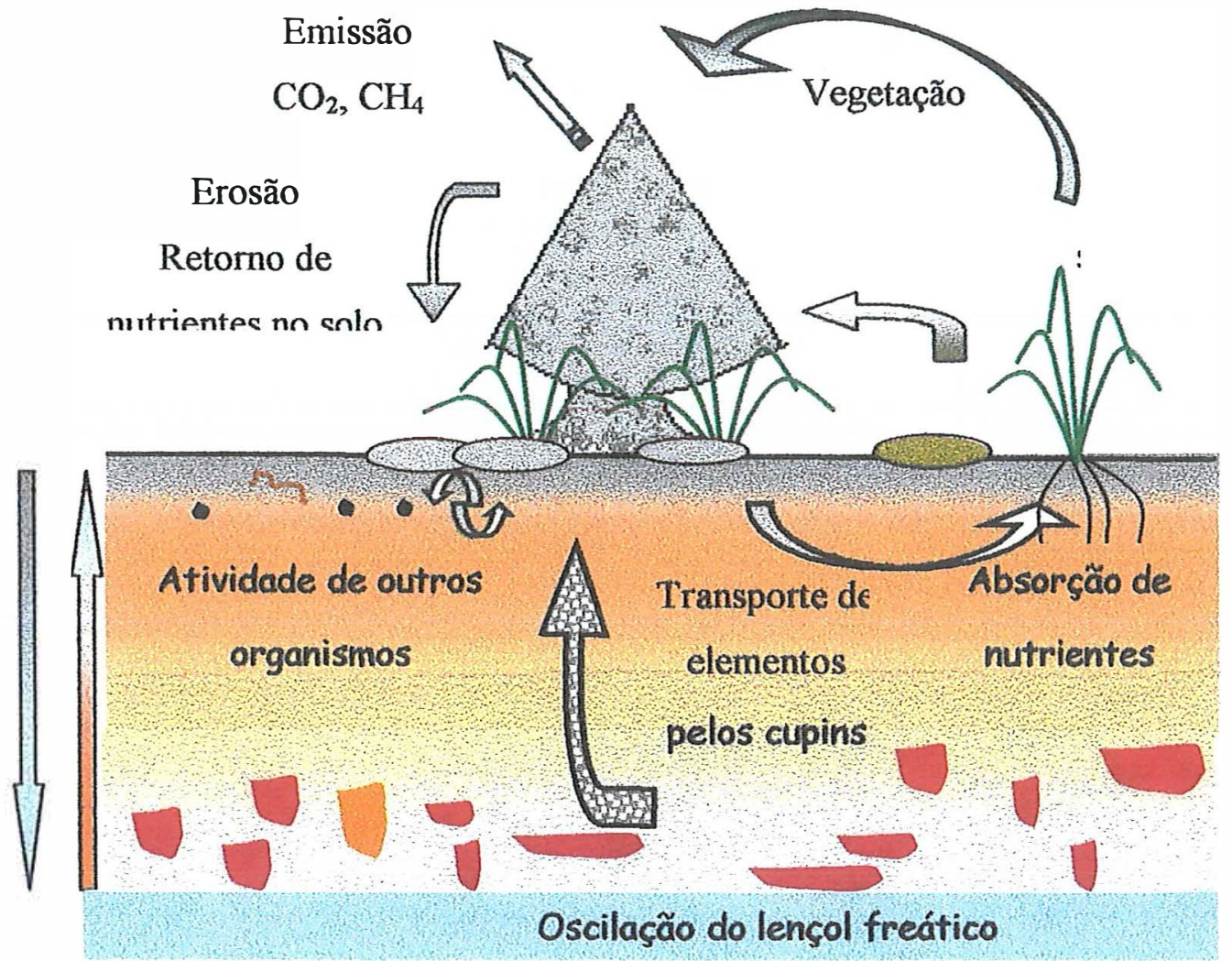

Figura 19 - Interação entre os cupinzeiros e o solo associado, com ênfase na ciclagem de elementos. 


\section{CONCLUSÕES}

Os cupins contribuem significativamente para a morfologia do solo, ao construir câmaras e galerias no perfil (formação de vazios), e para a transferência de partículas da subsuperficie para os montículos. Com a erosão dos montículos, os cupinzeiros são fundamentais para a dinâmica do horizonte superior do solo.

A transferência de materiais para câmaras e galerias encontradas no solo, na forma de revestimento de galerias, é fundamental para a ciclagem de nutrientes e elementos no solo estudado, principalmente de carbono.

A ausência da seleção de partículas pelos cupins está relacionada a granulometria muito fina do solo (predominância das frações silte e argila). Por este motivo, a composição mineralógica dos cupinzeiros é similar a encontrada no solo associado.

Os cupinzeiros apresentam maiores concentrações de carbono (3 vezes superior ao solo) e nutrientes (1,5 a 4,6 vezes superiores), em relação ao solo associado;

Para os teores de elementos totais, os cupinzeiros acumulam $\mathrm{Mn}, \mathrm{Ca}, \mathrm{Ba}$, $\mathrm{Sr}, \mathrm{Br}$ e Au.

As concentrações dos nutrientes e dos elementos maiores e traços supracitados, nos montículos, estão relacionadas ao acúmulo de matéria orgânica;

Apesar da grande quantidade de cupinzeiros $\left(608 \mathrm{ha}^{-1}\right)$ e das elevadas concentrações de nutrientes e de alguns elementos totais, os estoques são mínimos quando comparados com o solo associado. $\mathrm{O}$ fato está relacionado principalmente à pouca área coberta pelos montículos $(0,21 \%)$. 
APÊNDICES 
APÊNDICE 1 - Figuras 
Figura 20 - Vista geral da área de estudo (“Campos de Humaitá").

Figura 21 - Aspecto geral do cupinzeiro "G $\mathrm{G}_{3}$ " e suas respectivas câmaras e galerias.

(1) Altura da zona epígea: $43 \mathrm{~cm}$;

(2) Câmara de formiga do gênero Acromyrmex abandonada, preenchida por material cartunoso preto. Diâmetro $10 \mathrm{~cm}$. 
20

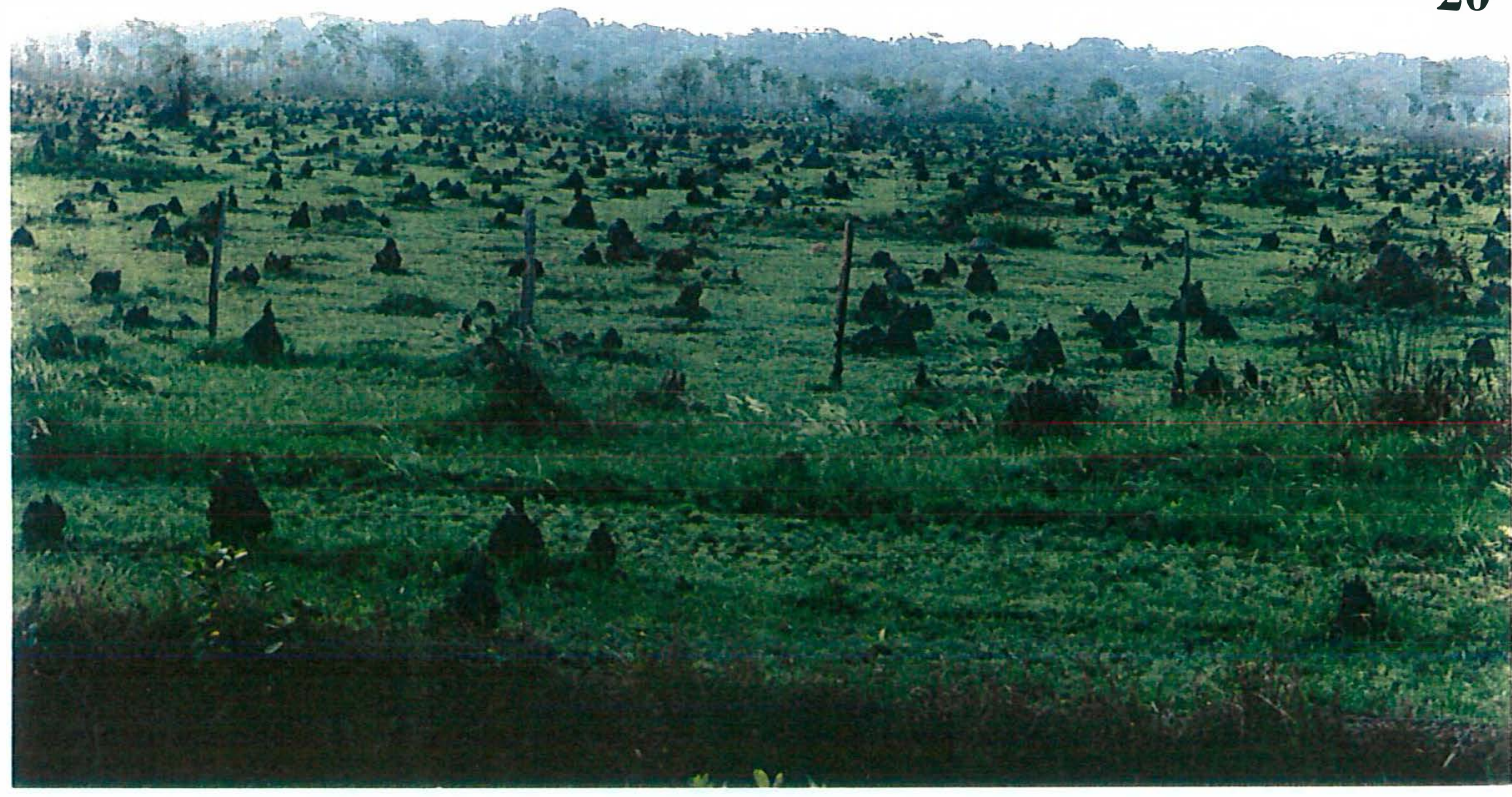

is

\%

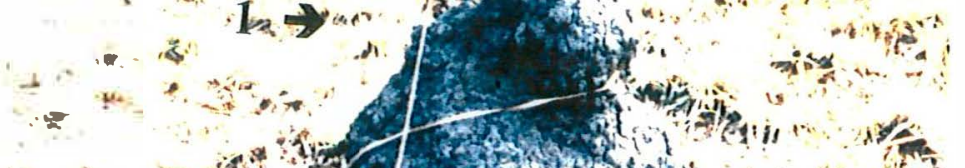

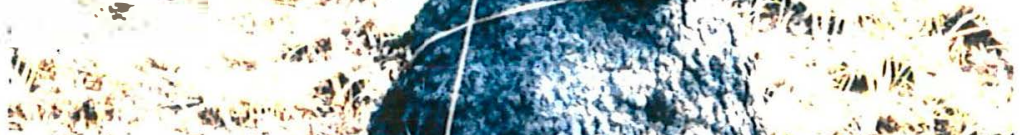

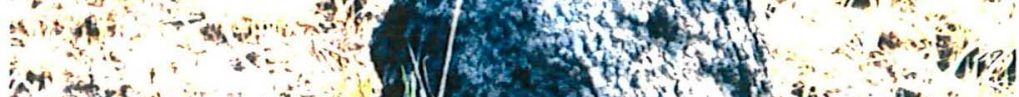

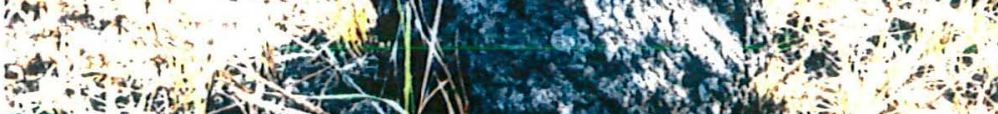
20.

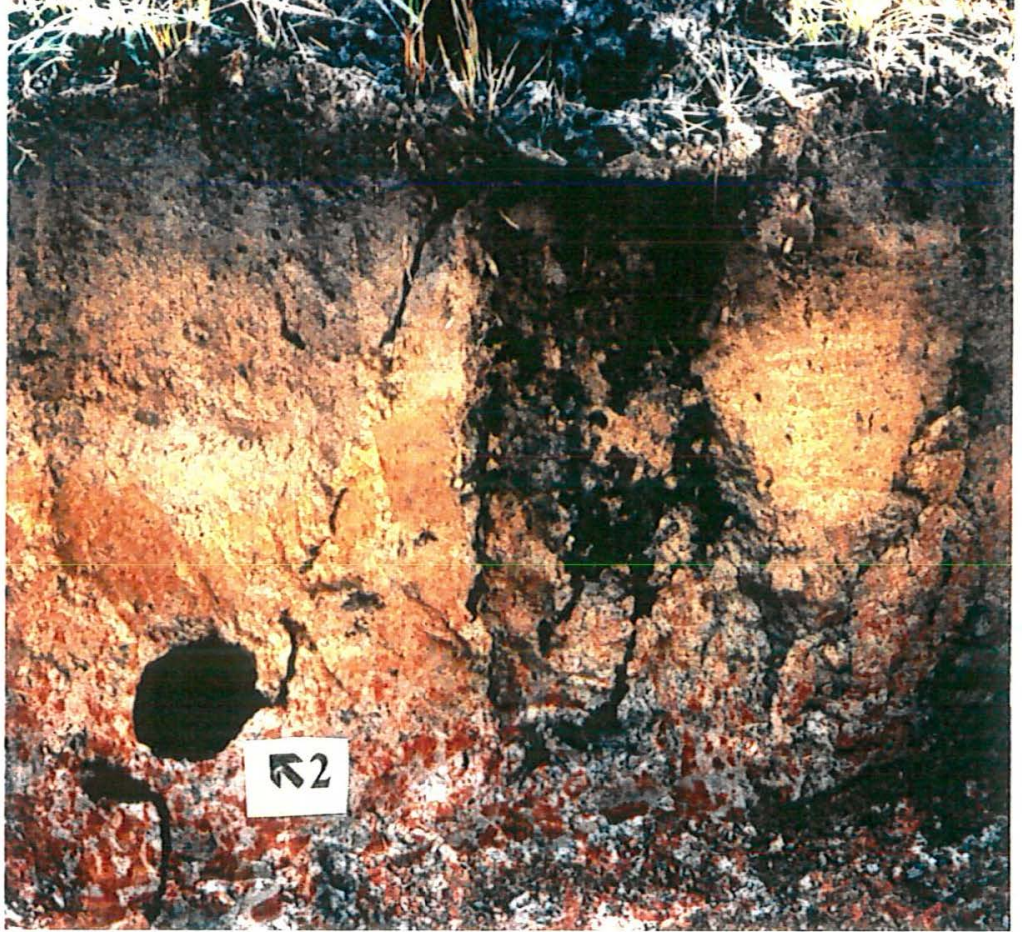


Figura 22 - Amostragem para análises físicas, químicas e da densidade aparente do solo, das camadas $0-15,15-30$ e $30-50 \mathrm{~cm}$.

Figura 23 - Corte vertical-axial de um cupinzeiro e do solo. Presença de fissuras no perfil.

Figura 24 - Corte longitudinal do solo ( 1 x $1 \mathrm{~m}$ ), expondo o início do horizonte pseudoglei. Detalhe da estruturação em blocos prismáticos. 

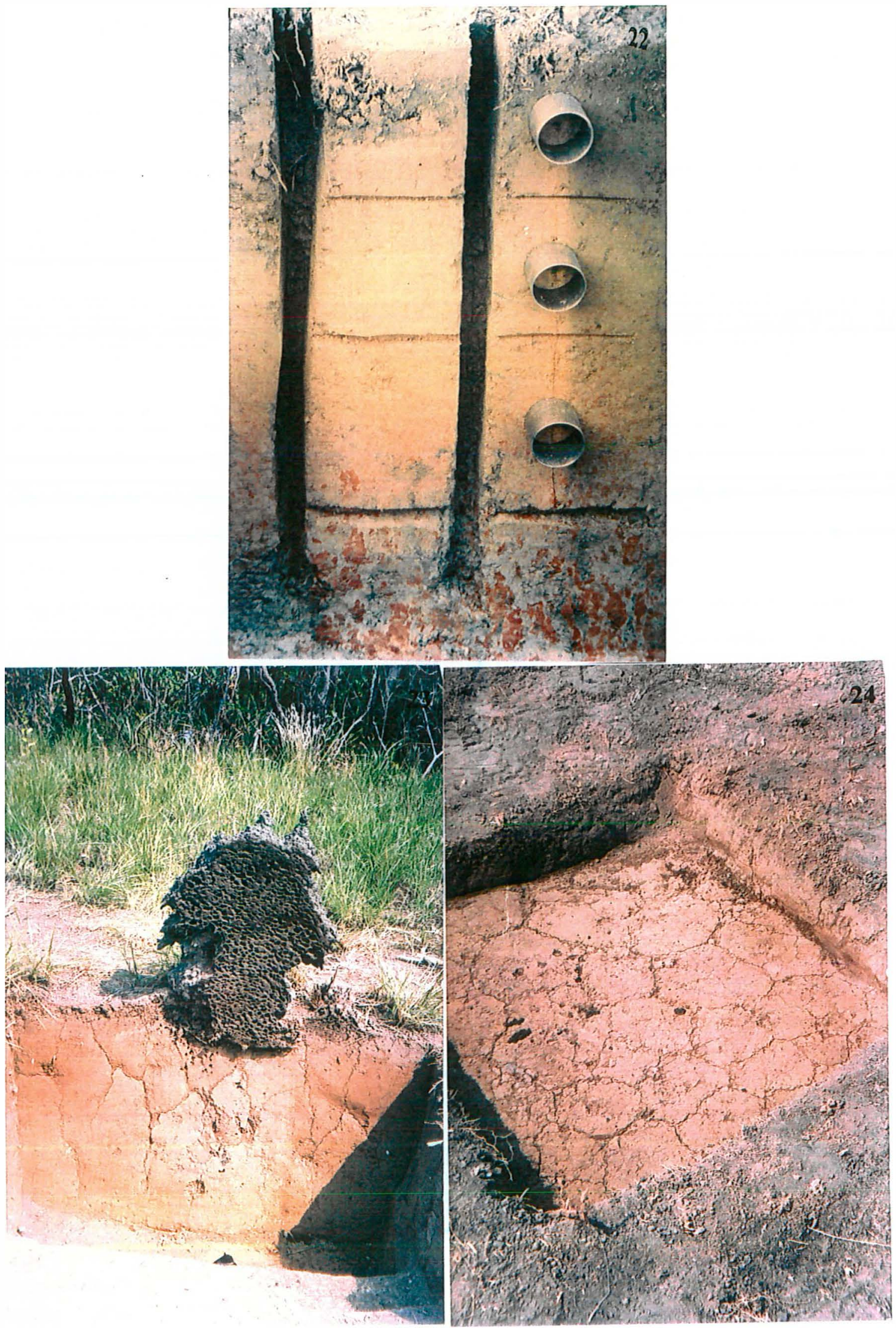
Figura 25 - Corte vertical - axial de um cupinzeiro $I_{3}$ (altura: $31 \mathrm{~cm}$ ) e do solo, evidenciando câmaras e galerias na trincheira.

Figura 26 - Detalhe das câmaras e galerias no solo, referente ao cupinzeiro $\mathrm{I}_{3}$ (Figura 25). Altura da imagem: $21 \mathrm{~cm}$. 
25
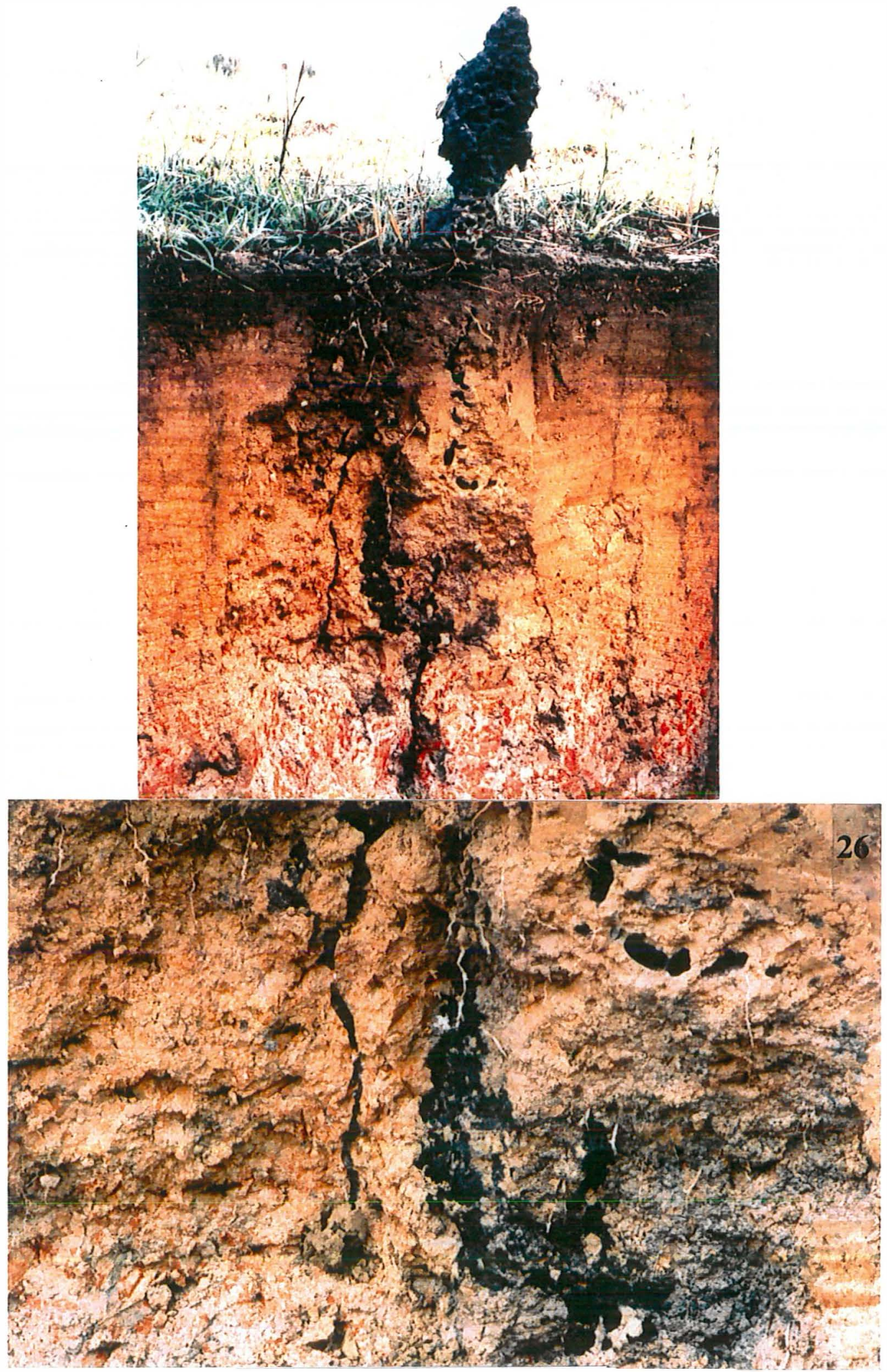
Figura 27 - Região central do cupinzeiro G3.

(1) deposições brunas nas paredes das câmaras;

(2) câmara real, cupular, com piso plano e teto arqueado. Largura: $3,5 \mathrm{~cm}$; altura: $1,0 \mathrm{~cm}$.

Figura 28 - Conexão entre câmaras, diâmetro $1,4 \mathrm{~mm}$. 


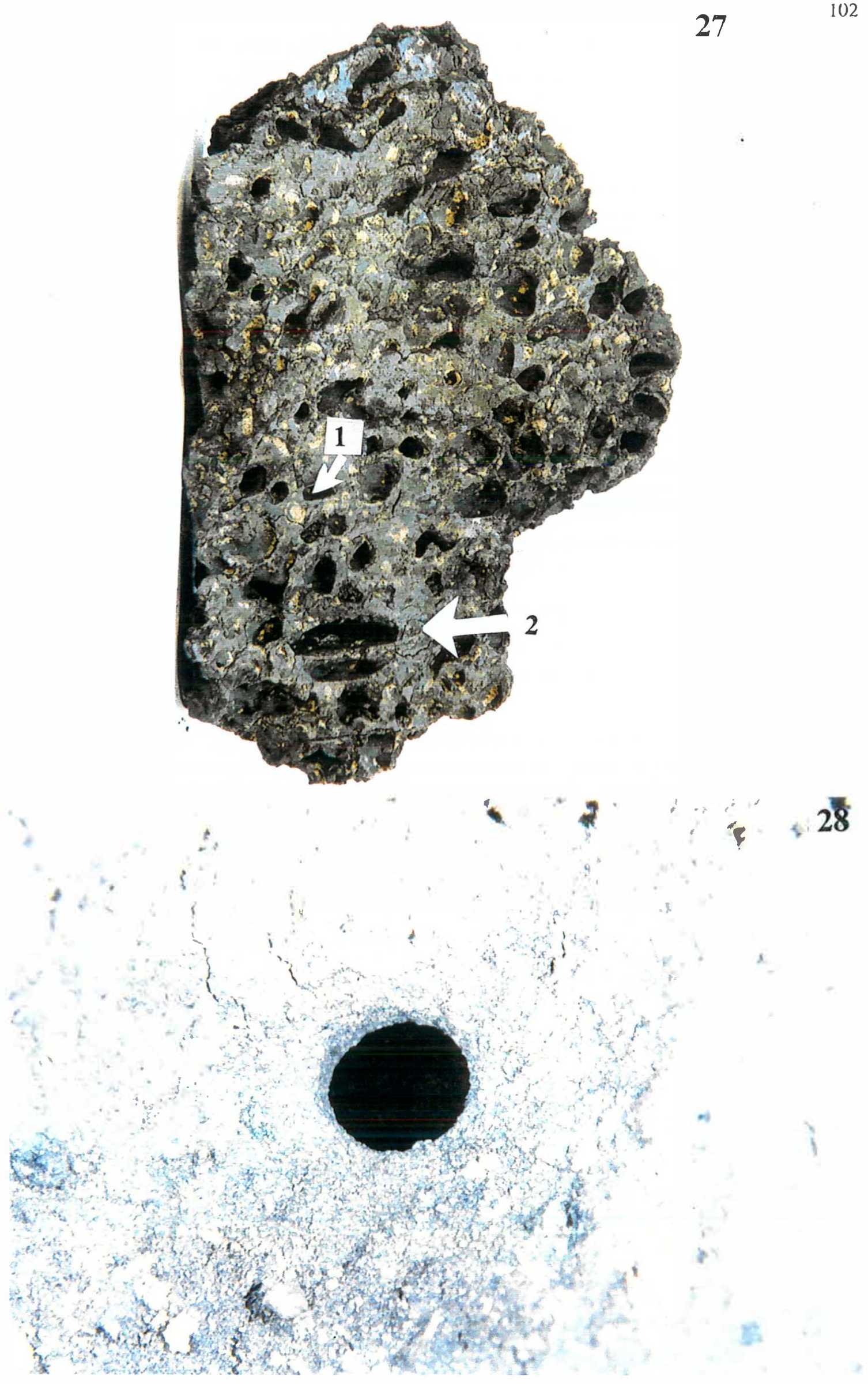


Figura 29 - Aspecto geral de uma câmara da zona epígea, com $2 \mathrm{~cm}$ de largura, próxima à câmara real. As deposições estão concentradas principalmente nos vértices.

Figura 30 - Detalhe de deposições localizadas no vértice de câmara, de diversas cores, formatos e tamanhos, coalescentes. Ao centro, deposição vermelha, regular discóide, com pequenas ondulações, bem aderida à parede, de $1 \mathrm{~mm}$ por 0,7 $\mathrm{mm}$. 

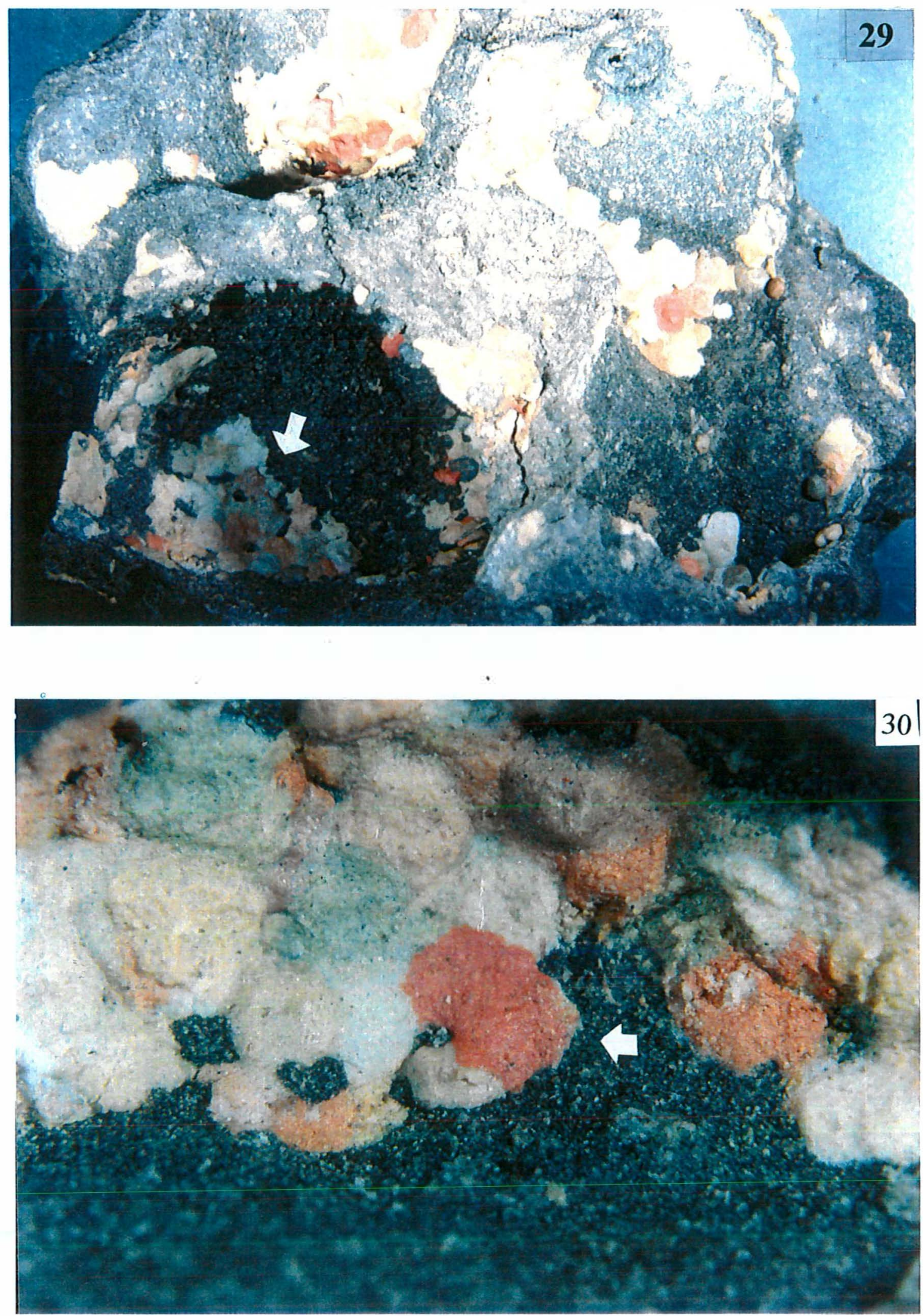
Figura 31 - Vértice de uma parede de câmara, construída em câmara abandonada da formiga Acromyrmex. Deposições sem contato entre si, discóides, com as seguintes características:

(1) branca, irregular ondulada a plana, $1,15 \times 0,8 \mathrm{~mm}$;

(2) vermelha, irregular paralelipédica ou quadrática, $0,7 \times 0,96 \mathrm{~mm}$, de espessura indefinida, porém apresentando ondulações em sua superficie; (3) branca irregular, diâmetro $0,7 \mathrm{~mm}$. Apresenta ondulações.

Figura 32 - Pelotas que não sofreram forte pressão pelos cupins, sendo:

(1) bruna escura, cupular, $0,4 \times 0,4 \times 0,24 \mathrm{~mm}$.

(2) vermelho, elipsoidal, $0,4 \times 0,4 \mathrm{~mm}$, espessura $0,52 \mathrm{~mm}$. 

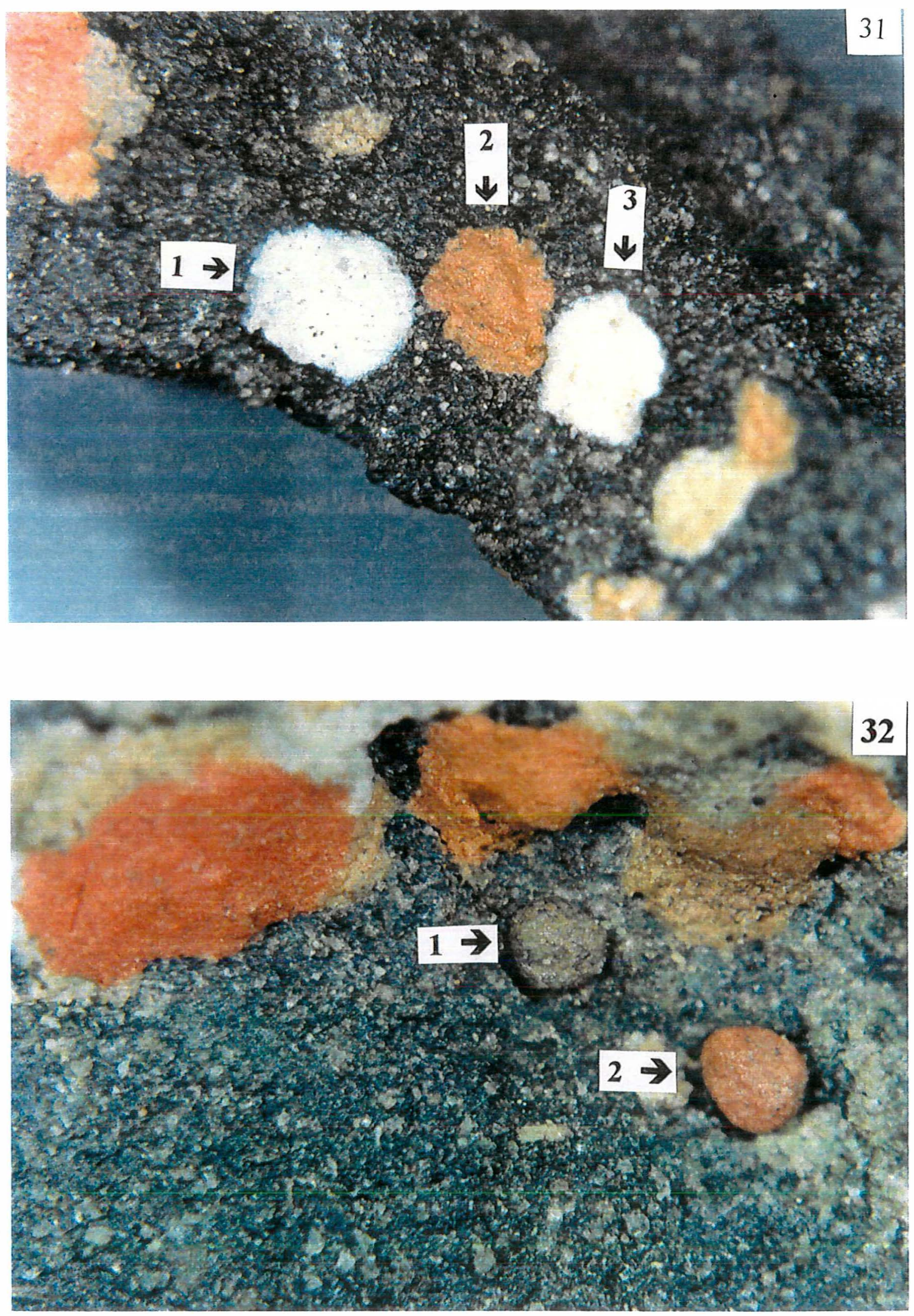
Figura 33 - Aspecto geral das deposições de diversas cores e formas. Indicado pela seta: pelota vermelha, de diâmetro $0,3 \mathrm{~mm}$.

Figura 34 - Parede de fissura, revestida por deposições pretas e brunas. No centro, pelota bruna, esferoidal, com diâmetro $0,4 \mathrm{~mm}$. 

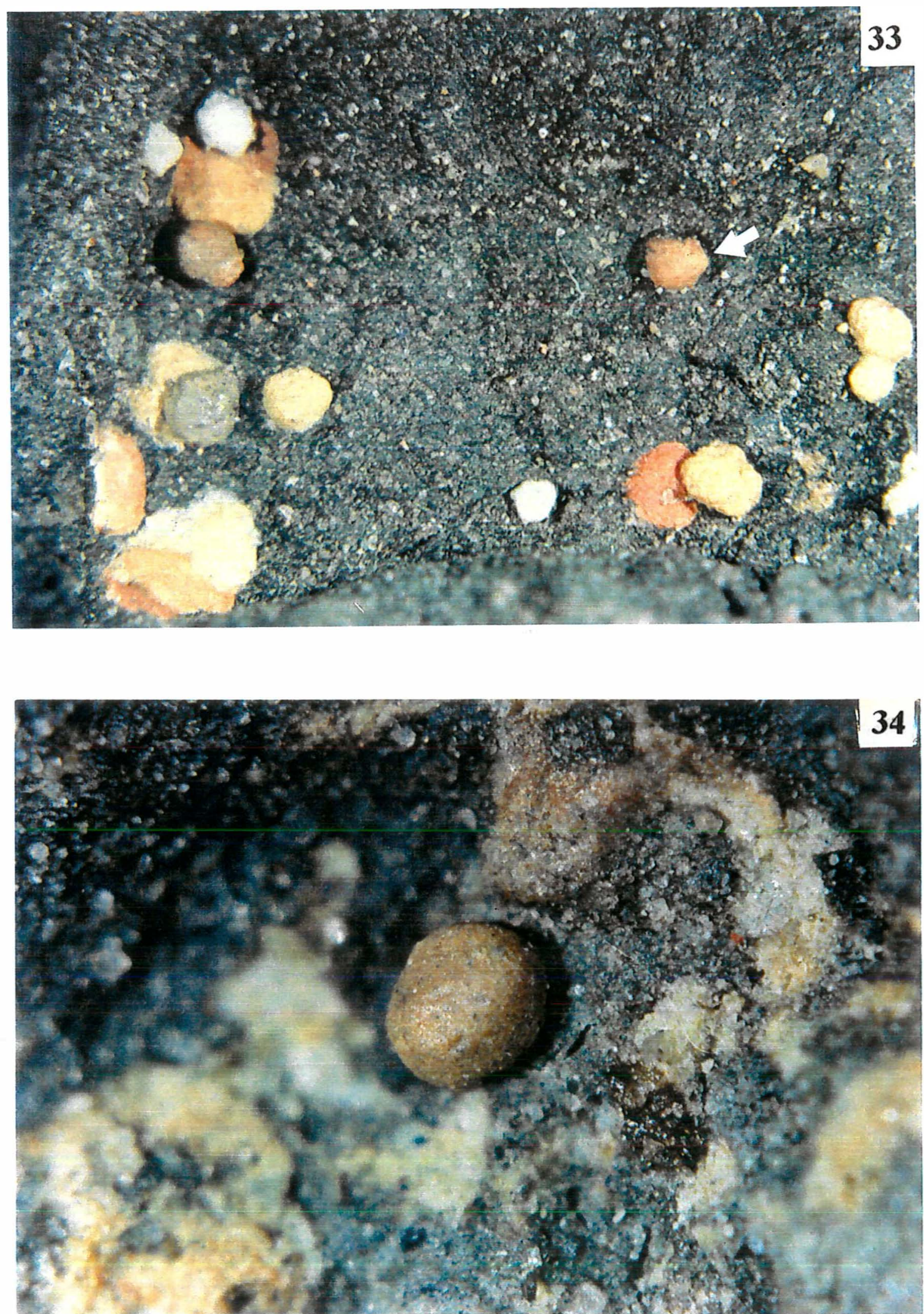
Figura 35 - Parede de obstrução em formação, constituída por pelotas pretas esferoidais, com diâmetro entre 0,5 e $0,8 \mathrm{~mm}$.

Figura 36 - Detalhe da de obstrução em formação. 

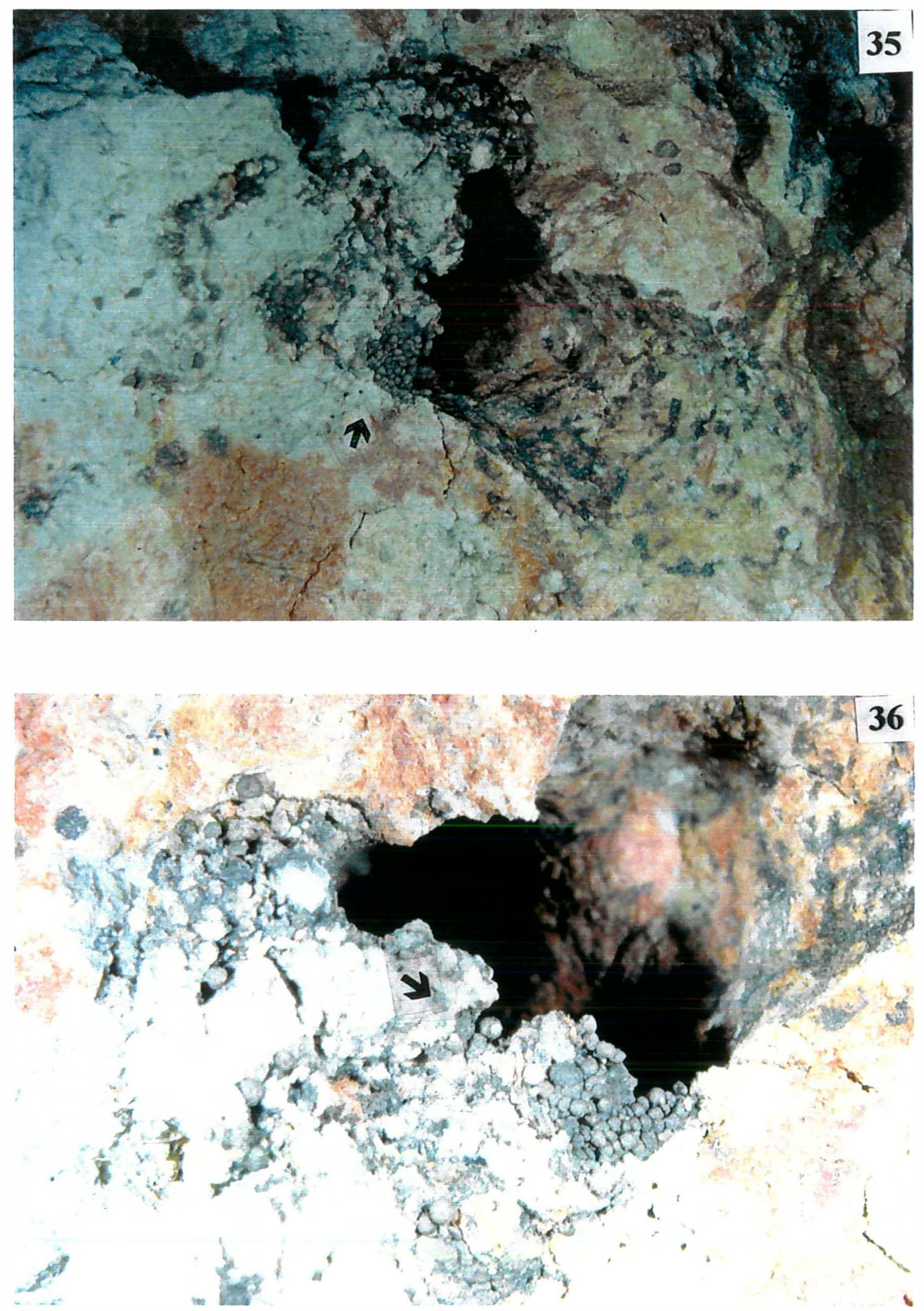
Figura 37 - Vértice de uma parede de câmara, construída em câmara abandonada da formiga Acromyrmex. Deposição de material vermelho, de diferentes tonalidades, sobre o material preto. Coalescência completa.

(1) Deposição vermelha escura, regular, seção circular, diâmetro $0,5 \mathrm{~mm}$ e espessura $0,2 \mathrm{~mm}$;

(2) parede de câmara.

Figura 38 - Superficie da câmara de formiga Acromyrmex, revestida por pelotas escuras, coalescentes. 

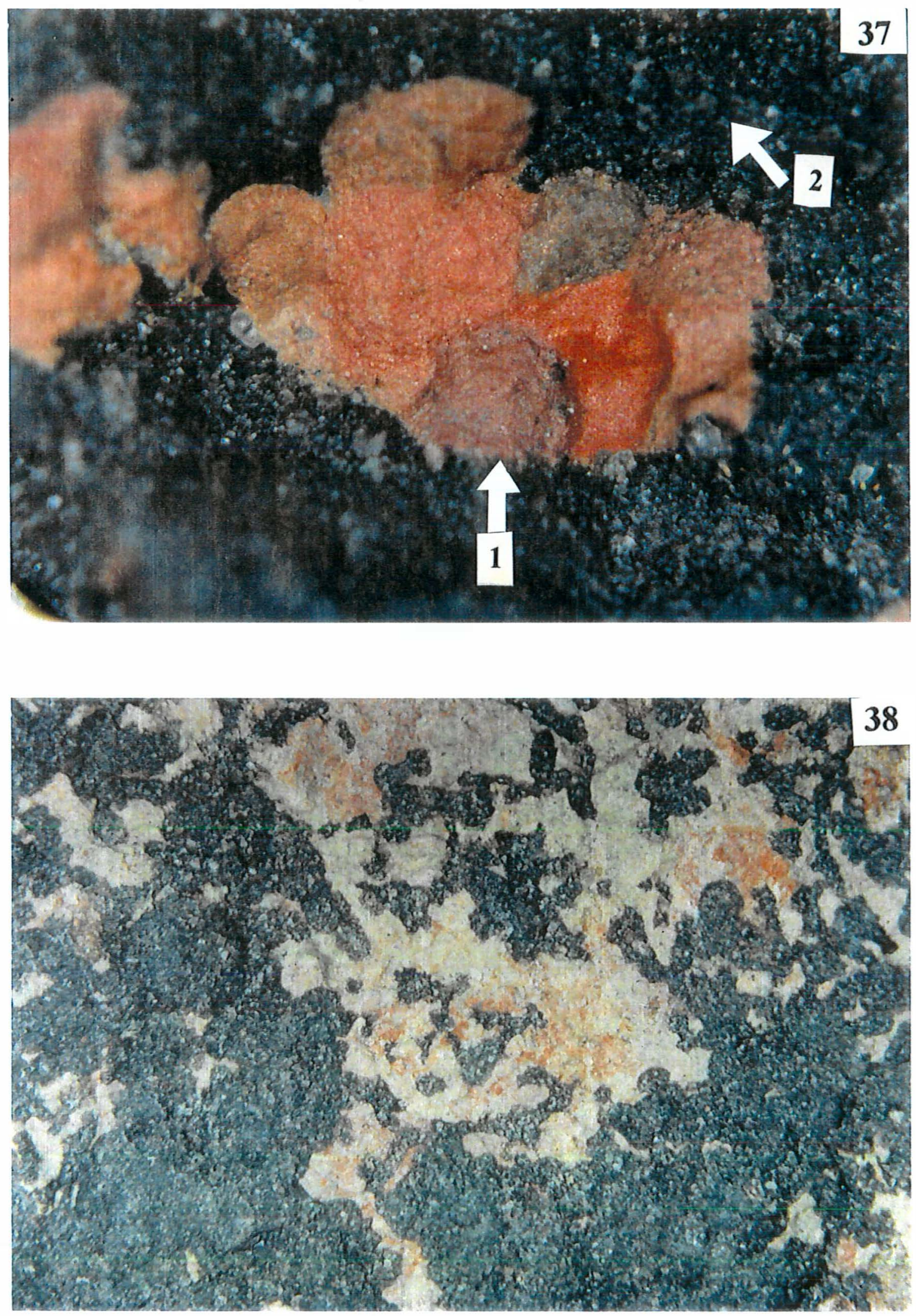


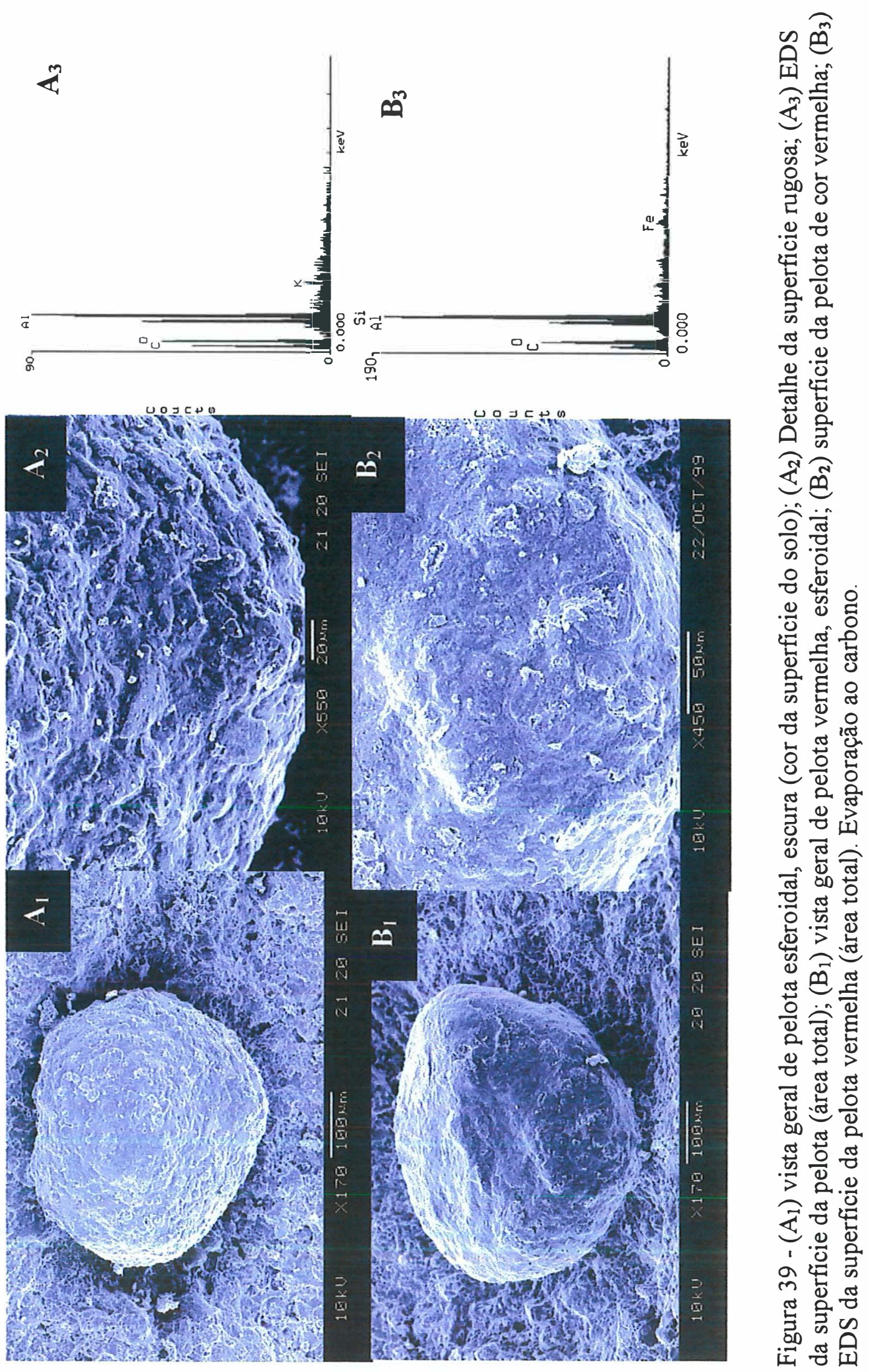




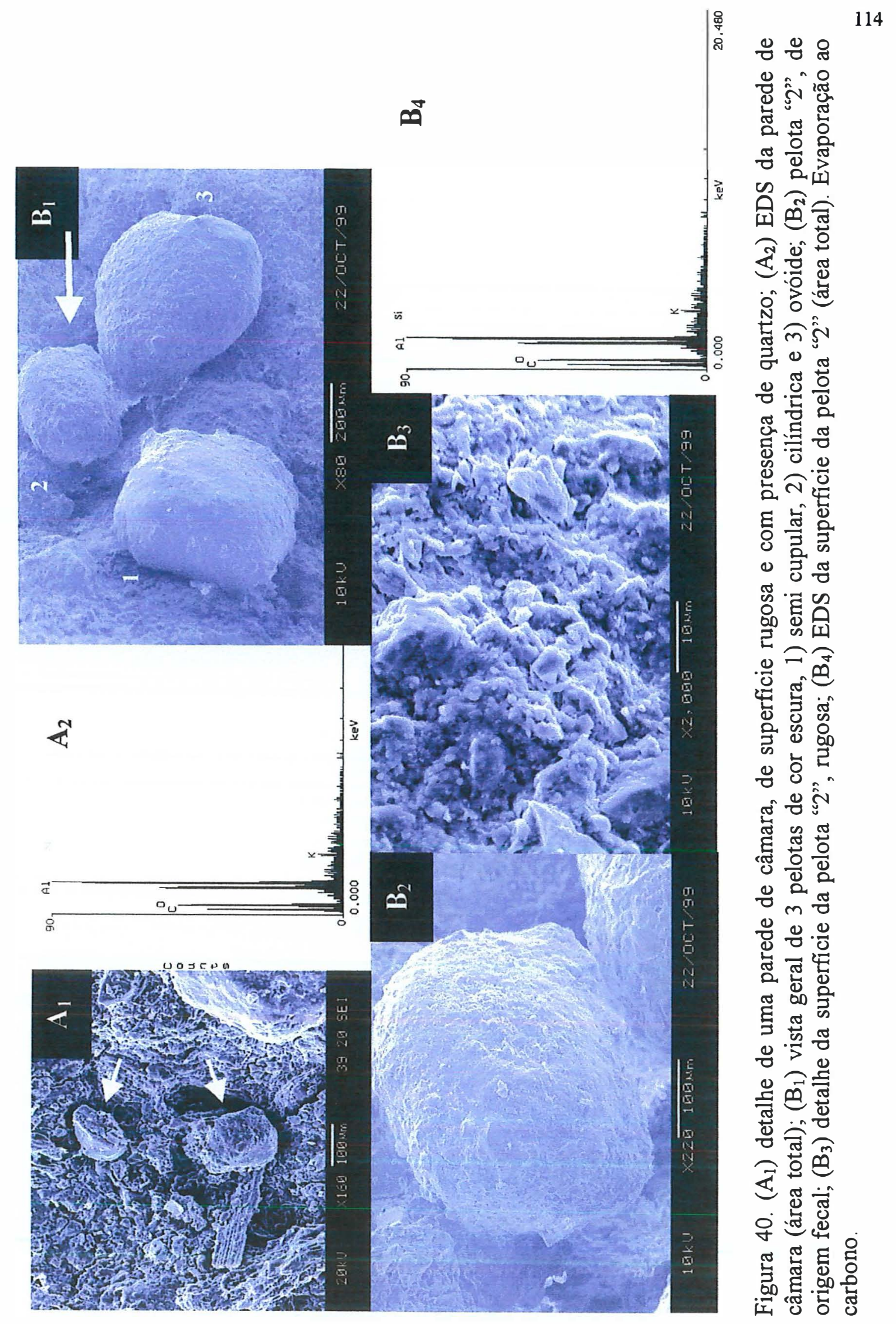




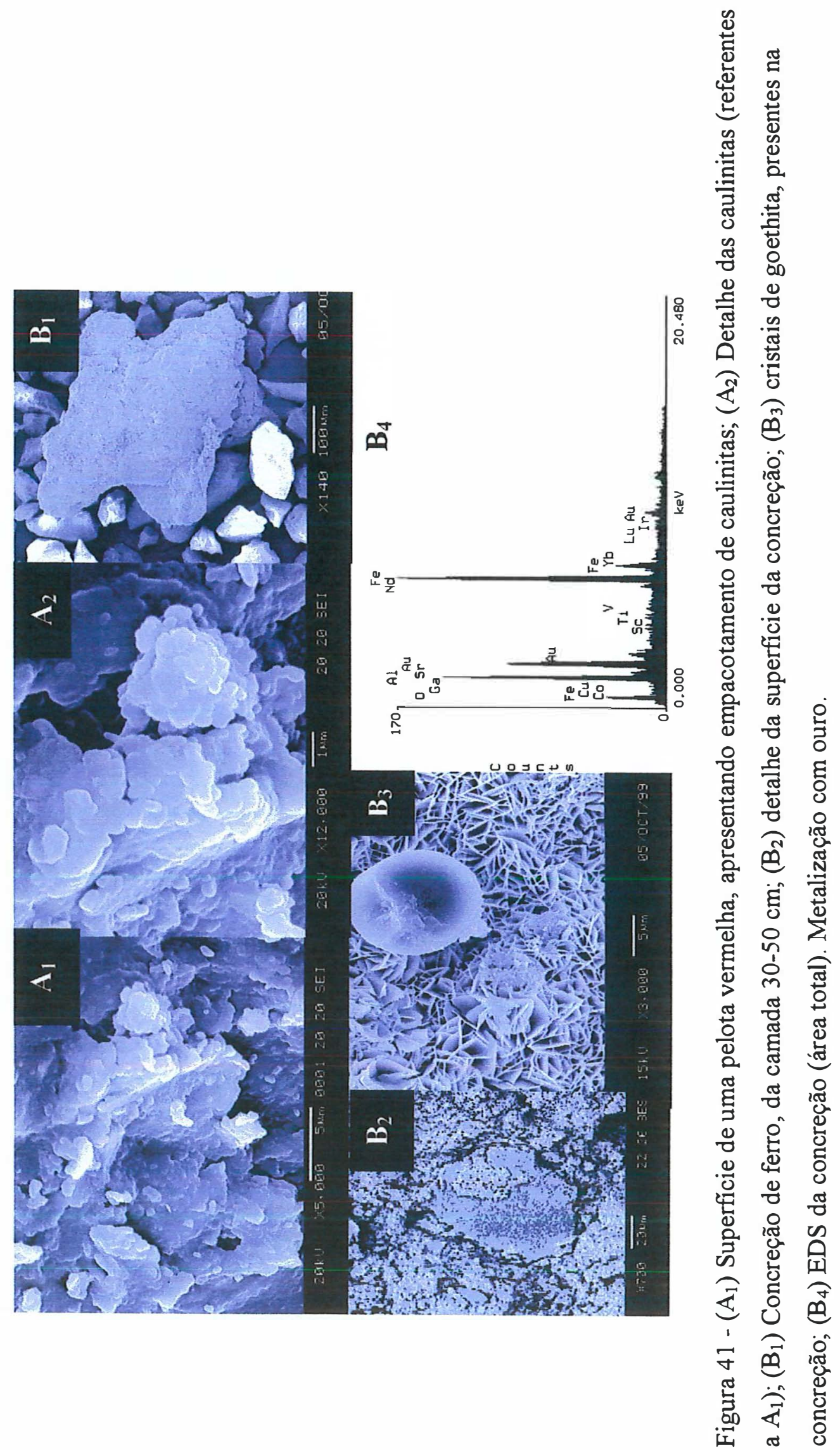




\section{APÊNDICE 2 - Caracterização morfológica do solo}

A11 0-3/8 cm; cinza (2,5 Y 4,5/1, seco) e preto (2,5 Y 2,5/1, úmido). Argilo-siltoso. Agregados granulares, irregulares, tamanho médio $1 \mathrm{~cm}$; duro, friável, não plástico, não pegajoso, sem fissuras; grande densidade de raízes finas. Poros tubulares menores que $0,5 \mathrm{~mm}$, muitos preenchidos por radicelas; poros de empilhamento de segunda ordem entre os agregados, de diâmetro médio 0,5 mm; galerias de cupins e câmaras de origem biológica (formigas e cupins); densidade total 10 seções $\mathrm{cm}^{-2}$. Isotúbulos preenchidos por material mineral cinza escuro, correspondente a atividade de minhocas, e granotúbulos de galerias e de câmaras, preenchidos por pelotas de cupins. Transição horizontal clara $(3 \mathrm{~cm})$.

A123/8-14/18 cm; cinza brunado (10 YR a 2,5 Y 5,5/2, seco) e cinza escuro a bruno (10 YR a 2,5 Y 3,5/2, úmido), com manchas amareladas. Argilo-siltoso. Prismática, diâmetro $20 \mathrm{~cm}$, que se desfaz em poliédrica sub-angulosa, de 1 a $3 \mathrm{~cm}$; duro, friável, não plástico, não pegajoso. Poros tubulares menores que $0,5 \mathrm{~mm}$, (muitos preenchidos por radicelas), de fissuras (diâmetro $1,5 \mathrm{~mm}$ ), galerias, e câmaras de origem biológica; abundância 10 seções $\mathrm{cm}^{-2}$. Isotúbulos preenchidos por coprólitos cinzas, resultante da atividade de minhocas, e granotúbulos, da atividade de cupins. Raízes verticais finas e abundantes. Transição ondulada clara $(3 \mathrm{~cm})$.

Bg 14/18 - 30/40 cm; cinza claro a bruno (10 YR a 2,5 Y 5,5/2, seco) e bruno acinzentado escuro - bruno muito escuro acinzentado (10 YR a 2,5 Y 3,5/2, úmido). Argilo siltoso. Prismática que se desfaz em poliédrica subangulosa, $1 \mathrm{~cm}$ diâmetro; duro, friável, ligeiramente plástico, ligeiramente pegajoso. Poros tubulares com diâmetro igual ou menor que 1,0 mm, de fissuras (diâmetro 1,5 $\mathrm{mm}$ ); galerias e câmaras biológicas; abundância poros (média) 10 secções $\mathrm{cm}^{-2}$. Isotúbulos preenchidos por coprólitos, pedotúbulos de galerias com revestimento 
de paredes preto descontínuo e granotúbulos de galerias (resultantes da atividade de cupins de outras espécies) e de câmaras (atividade de cupins e formigas); câmaras da formiga do gênero Acromyrmex vazias, parcialmente preenchida ou totalmente preenchida por grânulos cinza, com ou sem atividade de cupins. Coprólitos nas bordas de algumas câmaras. Raizes finas pouco abundantes. Transição horizontal abrupta $(1 \mathrm{~cm})$.

Bp 30/40 - $70 \mathrm{~cm}^{+}$; branco - cinza claro - bruno muito claro - amarelo claro (10 YR 7,5/1,5 a 2,5 Y 7,5/2, seco) e bruno amarelado claro - bruno amarelado - bruno oliváceo claro (10 YR a 2,5 YR 5,5/4, úmido); com variegados vermelhos. Argilo siltoso. Maciça, localmente poliédrica subangulosa com $1 \mathrm{~cm}$ diâmetro, pouco desenvolvida e fracamente estruturada; muito duro quando seco, firme quando úmido, ligeiramente plástico e ligeiramente pegajoso. Poros tubulares com 2-3 mm, ou menores; galerias e câmaras de atividade biológica; abundância 10 seç̧ões $\mathrm{cm}^{-2}$. Pedotúbulos de galerias, preenchidos por coprólitos. Raízes finas pouco abundantes. 


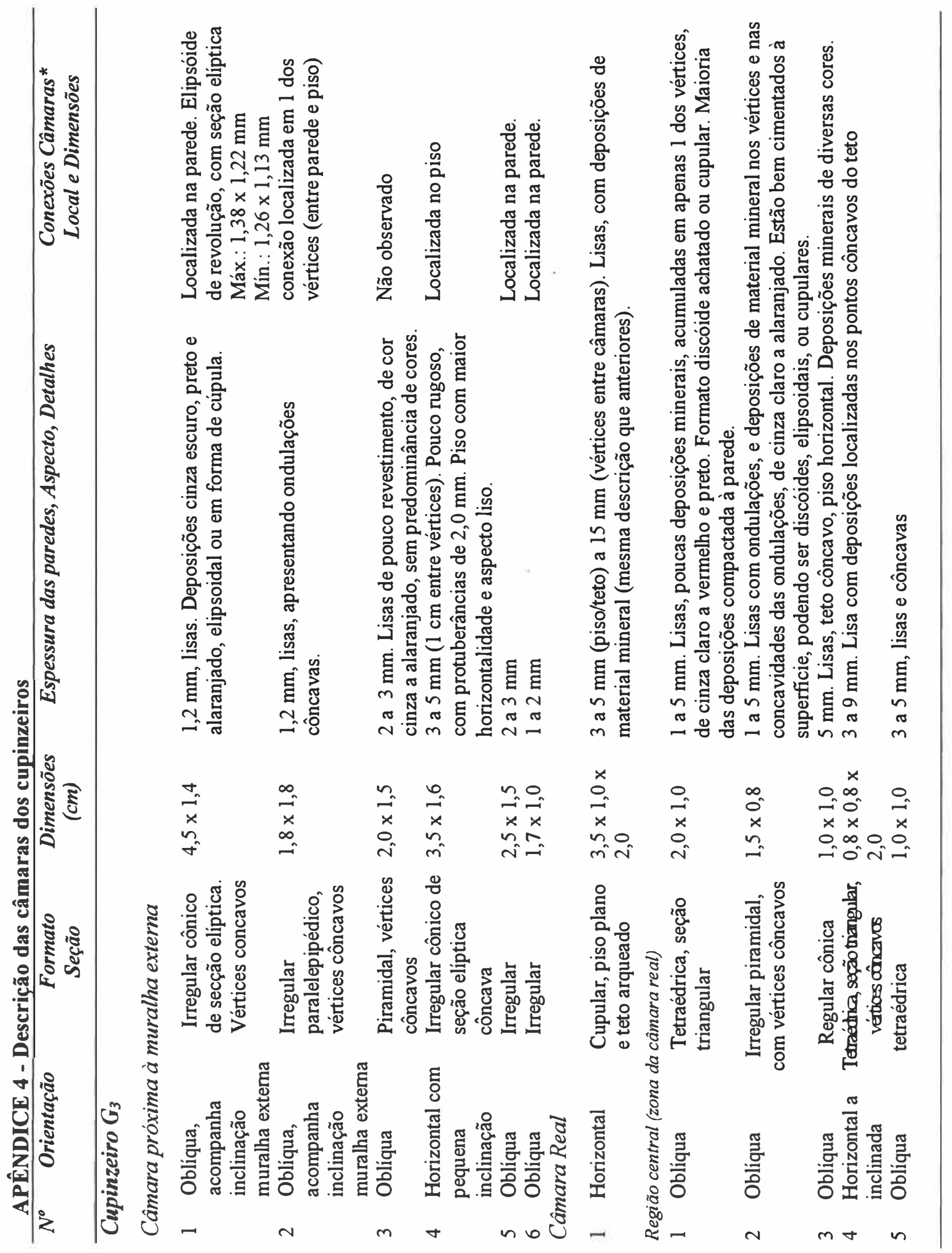




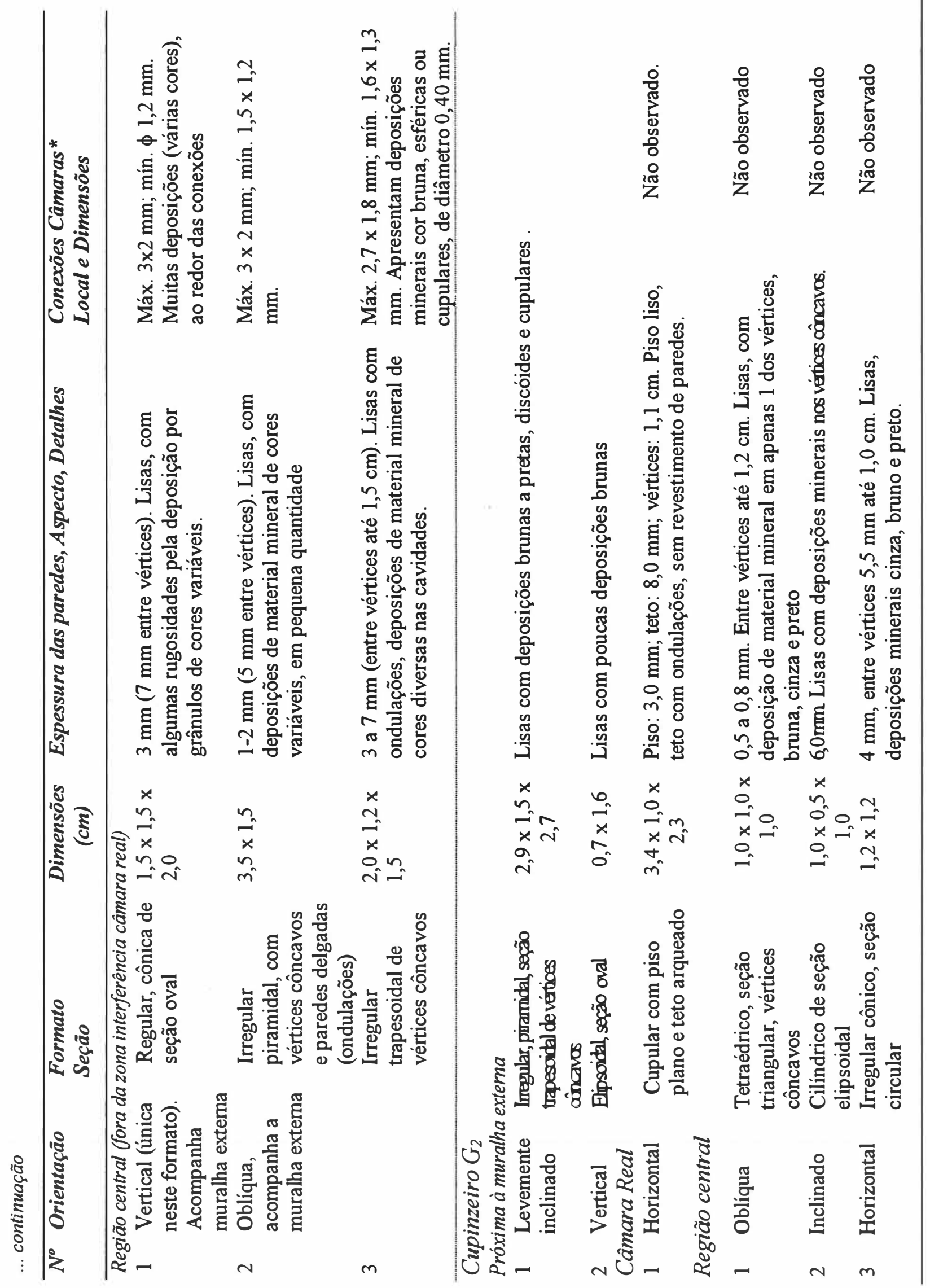




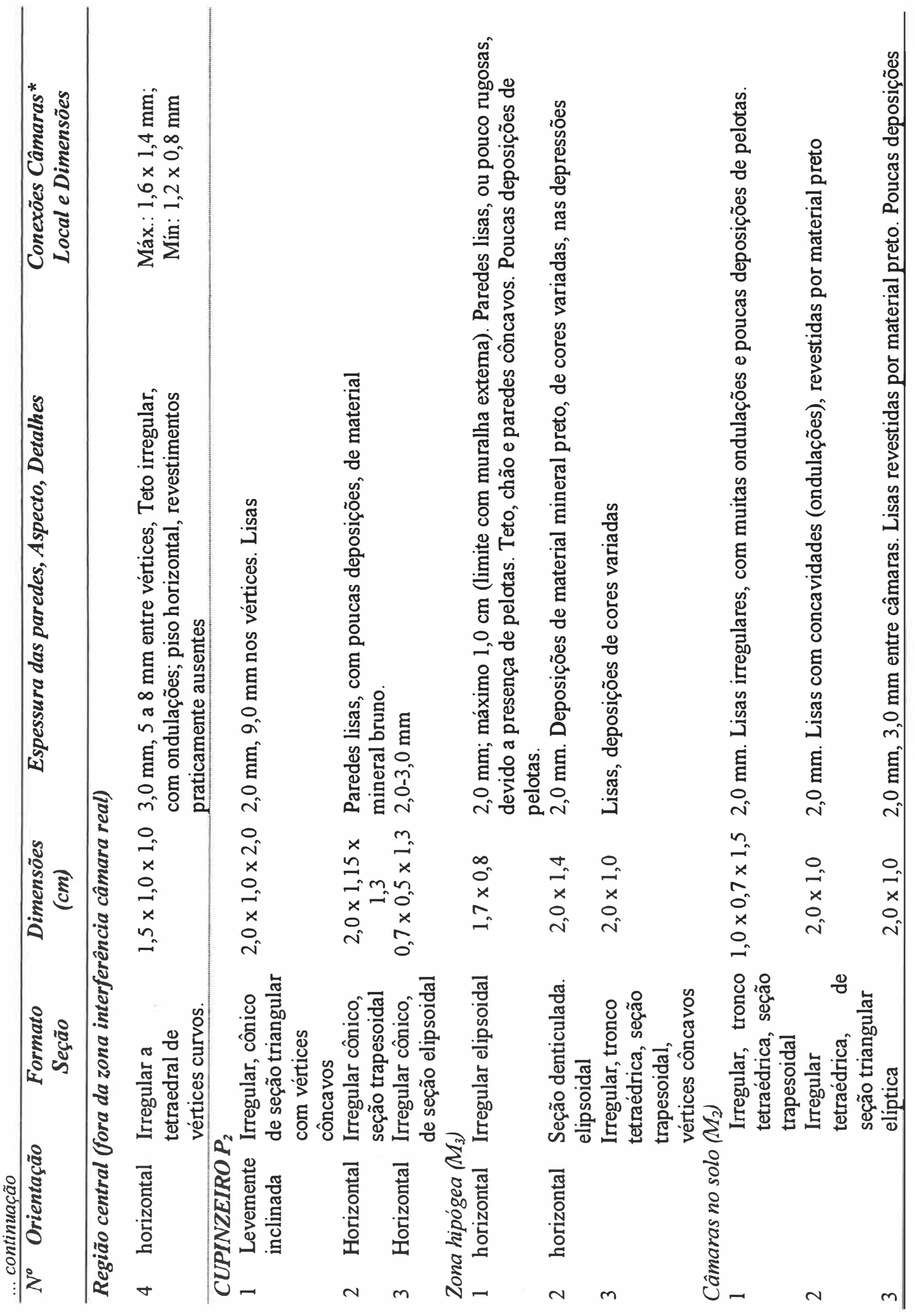




\section{REFERÊNCIAS BIBLIOGRÁFICAS}

AMARAL FILHO, Z.P. do; NEVES FILHO, J.P.; CUNHA, N.G. da Folha SC 20 Porto Velho. III - Pedologia. In: BRASIL. Ministério de Minas e Energia. Departamento Nacional de Produção Mineral. Projeto RADAMBRASIL: Folha SC 20: Porto Velho; geologia, geomorfologia, pedologia, vegetação e uso potencial da terra. Rio de Janeiro, 1978. v. 16, p.251-412.

ANDERSON, J.M. Spatiotemporal effects on invertebrates on soil processes. Biology and Fertility of Soils, v.6, p.216-227, 1988.

BALASHOV, Y.A.; GIRIN, Y.P. On the reserve of mobile rare earth elements in sedimentariy rocks. Geochemica International, v.6, p.649-659, 1969.

BANDEIRA, A.G. Termites (Insecta: Isoptera) consumidores de liteira na Ilha de Maracá, Roraima. Acta Amazonica, v.21, p. 15-23, 1991.

BAROIS, I; LAVELLE, P. Changes in respiration rate and some physicochemical properties of a tropical soil during transit through Pontoscolex corethrurus (Glossoscolecidae, Oligochaeta). Soil Biology and Biochemistry, v.18, p.539-541, 1986. 
BARONI-UBANI C.; JOSENS, G; PEAKIN, G.J. Empirical data and demographic parameters. In: BRIAN, M.V. (Ed.) Production ecology of ants and termites. Cambridge: Cambridge University Press, 1978. p.5-44.

BARROS, M.E.; BLANCHART, E.; DESJARDINS, T.; CHAUVEL, A.; SARRAZIN, M.; LAVELLE, P. Relação entre a macrofauna e a agregação do solo em três sistemas na Amazônia Central (compact disc). In: CONGRESSO LATINOAMERICANO DE CIÊNCIA DO SOLO, 13., Águas de Lindóia, 1996. Solo-suelo 96: trabalhos. Piracicaba: SBCS/SLCS, 1996.

BASU, P.; BLANCHART, E.; LEPAGE, M. Termite (Isoptera) community in the Western Ghats, South India: influence of anthropogenic disturbance of natural vegetation. European Journal of Soil Biology, v. 32, n.3, p. 113-121, 1996.

BOYER, P. Quelques aspects de l'action des termites du sol sur argiles. Clay Mineralogy, v.17, p. 453-504, 1982.

BRABANT, P. Le sol des forêts claires du Cameroum. s.l. ORSTOM, s.d. t.1, 530p.

BRASIL. Ministério da Agricultura e Reforma Agrária. Secretaria Nacional de Irrigação. Departamento Nacional de Meteorologia. Normas climatológicas (19611990). Brasília, 1992. 84p.

BROWN, G.G. How do earthworms affect microfloral and faunal community diversity? Plant and Soil, v.170, p.209-231, 1995.

BRUYN, L.A.L; CONACHER, A.J. Soil modification by termites in the Central Wheatbelt of Western Australia. Australian Journal of Soil Research, v.33, p.179-193, 1995. 
BUOL, S.W.; HOLE, R.D.; McCRACKER, R.J.; SOUTHARD, R.J. Soil genesis and classification. Ames: Iowa State University Press, 1997. cap.3, p.107-142: Biogeochemical process in soil formation.

DIXON, J.B.; WEED, S.B.; KITTRICK, S.B.; MILFORD, M.H.; WHITE, J.L. Mineral in soil environments. Madison: Soil Science Soiciety of America, 1987. 948p.

CHEN, J. HENDERSON, G. GRIMM, C.C.; LLOYD, S.W.; LAINE, R.A Termites fumigate their nests with naphthalene. Nature, v.392, p.558-559, 1998.

CURRY, J.P.; GOOD, J.A. Soil faunal and restoration. Soil Science, v.17, p.171-215, 1992

DOI, S.; GUIMARÃES, J.G.; DILMAN, M.S.; BARROS-SILVA, S. Folha SC 20 Porto Velho. IV - Vegetação. In: BRASIL. Ministério de Minas e Energia. Departamento Nacional de Produção Mineral. Projeto RADAMBRASIL: Folha SB 20: Purus; geologia, geomorfologia, pedologia, vegetação e uso potencial da terra. Rio de Janeiro, 1978. v.17, p.367-490.

DOMINGOS, D. J. Preferência alimentar de Armitermes euamignathus (Isoptera, Termitidae, Nasutitermitinae) em cinco formações vegetais do cerrado. Revista Brasileira de Biologia, v.43, n.4, p.339-344, 1983.

EMPRESA BRASILEIRA DE PESQUISA AGROPECUÁRIA. Manual de métodos de análise de solos. Rio de Janeiro, 1997. 212 p. (EMBRAPA: SNPS. Documentos, 1).

EMPRESA BRASILEIRA DE PESQUISA AGROPECUÁRIA. Sistema brasileiro de classificação de solos. Rio de Janeiro, 1999, 412 p.

ESCHENBRENNER, V. Contribuition des termites à la micro-agrégation des sols tropicaux. Cahier ORSTOM, Série Pedologie, v.22, n.4, p.397-408, 1986. 
ESCHENBRENNER, V. Termites activity and soil morphology in tropical areas (compact disc). In: CONGRESSO LATINO-AMERICANO DE CIÊNCIA DO SOLO, 13., Águas de Lindóia, 1996. Solo-suelo 96: trabalhos. Piracicaba: SBCS/SLCS, 1996.

ESWARAN, H.; SYS, C. An evaluation of the free iron in tropical basaltic soils. Pedologie, v.20, p.62-85, 1970.

FLACH, W.; CADY, J.G.; NETTELTON, W.D. Pedogenetic alteration of highly weathered parent material. In: INTERNATIONAL CONGRESS OF SOIL SCIENCE, 9., Adelaide, 1968. Proceedings. v.4, p.343-351.

GARNIER-SILLAM, E.; HARRY, M. Distribution of humic compounds in mounds of some soil-feeding termites species of tropical rainforest: its influence on soil structure stability. Insectes Sociaux, v. 42, p. 167-185, 1995.

GOMES, P.C. Influência da cobertura vegetal na formação e evolução do húmus e sua relação com algumas propriedades físico-químicas de um Latossolo Vermelho Amarelo do Município de Viçosa-MG. Viçosa, 1992. 60p. Dissertação (Mestrado) - Universidade Federal de Viçosa.

GRASSÉ, P.P. Termitologia. Anatomie, phisiologie, biologie systématique des termites. Tome 2: Fondation des sociétés-Constructions. Massom: Foundation Singer Polignac, 1984. 676p.

HOLE, F.D. Effects of animals on soil. Geoderma, v.25, p. 75-112, 1981.

HUTTON, J.T.; OSMOND, G. Titanium and zirconium minerals. In: DIXON, J.B.; WEED, S.B.; KITTRICK, S.B.; MILFORD, M.H.; WHITE, J.L. Mineral in environments. Madison: Soil Science Soiciety of America, 1998, p.673-687. 
JACKSON, M.L. Soil chemical analysis: advance course. Madison: University of Wisconsin, Department of Soil Science, 1969. 895p.

JONES, J.A. Termites, soil fertility and carbon cycling in dry tropical Africa: a hypothesis. Journal of Tropical Ecology, v.6, p.291-305, 1990.

KABATA-PENDIAS, A; PENDIAS, $H$. Trace elements in soil and plants. Boca Raton: CRC Press, 1984. 315p.

KIEHL, E.J. Manual de edafologia. São Paulo: CERES, 1979. 262p.

KOUTIKA, L.S.; CHONE, T.; ANDREUX, F.; BURTIN, G.; CERRI, C.C. Factors influencing carbon decomposition of topsoil from the Brasilian Amazon Basin. Biology and Fertility of Soils, v.28, n.4, p.436-438, 1999.

LAL, R. Tropical ecology and physical edaphology. Chichester: Wiley- Interscience, 1987. cap. 2, p.229-423: Ecological factors and soil physical properties.

LAVELLE, P. Earthworm activitie and the soil system. Biology and Fertility of Soils, v.6, p.237-251, 1988.

LAVELLE, P.; PASHANASI, B. Soil macrofauna and land management in Peruvian Amazonia (Yurimaguas, Loreto). Pedobiologia, v.33, p.283-291, 1989.

LAVElle, P.; MELENDEZ, G.; PASHANASI, B.; SHAEFER, R. Nitrogen mineralization and reorganization in casts of the geiphagous tropical earthworm Pontscolex corethrurus (Glossoscolecidae). Biology and Fertility of Soils, v.14, p.49-53, 1992. 
LAVELLE, P.; DANGERFIELD, M; FRAGOSO, C.; ESCHENBRENNER, V.; LOPEZ-HERNANDEZ, D.; PASHANASI, B.; BRUSSAARD, L. The relationship between soil macrofauna and tropical soil fertility. In: WOOMER, P. L.; SWIFT, M. J. (Ed.) The biological management of tropical soil fertility. Chichester: John Wiley, 1994. cap.4, p. 137-170.

LEE, K.E.; WOOD, T.G. Termite and soil. New York: Academic Press, 1971. 251p.

LEMOS, R.C.; SANTOS, R.D. Manual de descrição e coleta do solo no campo. Campinas: Sociedade Brasileira de Ciência do Solo e Serviço Nacional de Levantamento e Conservação de Solo, 1982. 45p.

LOPES ASSAD, M.L. Fauna do solo. In: VARGAS, M.A.T.; HUNGRIA, M. (Ed.) Biologia dos solos dos cerrados. Planaltina: EMBRAPA, CPAC, 1997. cap.7, p.363-443.

LOPES ASSAD, M.L.; LACERDA, R.C.A. Caracterização de cupinzeiros em áreas de pastagem degradada da região dos cerrados. In: CONGRESSO BRASILEIRO DE CIÊNCIA DO SOLO, 25. Viçosa, 1995. Resumos Expandidos. Viçosa: UFV, 1995. v.1, p.445-447.

LÓPEZ-HERNÁNDEZ, D.; FARDEAU, J.C.; NIÑO, M.; NANNIPIERI, P.; CHACON, P. Phosphorus accumulation in savanna termite mound in Venezuela. Journal of Soil Science, v.40, p.635-640, 1989.

MANDO, A.; STROOSNIJDER, L.; BRUSSAARD, L. Effects of termites on infiltration into crusted soil. Geoderma, v. 74, n. 1/2, p. 107-113, 1996.

MARTINEZ-DELCLOS; MARTINELL, J. The oldest known record of social insects. Journal of Paleontology, v.69, n.3, p.594-599, 1995. 
MARTINS, E.S. Papel das térmitas na formação do solo: um tema de abordagem. In: CONGRESSO BRASILEIRO DE CIÊNCIAS DO SOLO, 24. Goiânia, 1993. Resumos. Goiânia: SBCS, 1993. p.33-35.

MARTIUS, C. Diversity and ecology of termites in Amazonian forest. Pedobiologia, v.38, n.5, p.407-428, 1994.

MERMUT, A.R.; ARSHAD, M.A.; ARNAUD, R.S.ST. Micropedologicak study of termite mound of three species of Macrotermes in Kenya. Soil Science Society of America Journal, v.48, p.613-620, 1984.

NYE, P.H. Some soil-forming processes in the humid tropics in the action of the soil fauna. Journal of Soil Science, v.6, p.73-83, 1955.

OADES, J.M. Soil organic matter and structural stability: mecanisms and implications for management. Plant and Soil, v.76, p.319-337, 1984.

PAVAN, M.A. Alumínio em solos ácidos do Paraná: relação entre o alumínio não trocável, trocável e solúvel, com o $\mathrm{pH}, \mathrm{CTC}$, porcentagem de saturação de $\mathrm{Al}$ e matéria orgânica. Revista Brasileira de Ciência do Solo, v.7, n. 1, p.36-46, 1983.

PERES FILHO, O.; SALVATORI, J.R.; SANCHEZ, G.; NAKANO, O.; TÉRAN, F.O. Componentes do material utilizado na construção do termiteiro do cupim-demontículo, (Isoptera: Termitidae). Pesquisa Agropecuária Brasileira, v.25, n.2, p.167-171, fev. 1990.

PINHEIRO, C.S.S.M; BATISTA, R.B.; QUEIROZ, S.B. Alterações morfológicas em perfis de solos afetados por cupins no município de Areia - PB. In: CONGRESSO BRASILEIRO DE CIÊNCIA DO SOLO, 24. Goiânia, 1993. Resumos. Goiânia: SBCS, 1993. p.259-260. 
PRESTWICH, G.D.; BENTLEY, B.L. Nitrogen fixation in intact colonies of the termite Nasutitermes corniger. Oecologia, v.49, p.249-251, 1981.

RAIJ, B. van; QUAGGIO, J.A Métodos de análise de solo para fins de fertilidade. Campinas, Instituto Agronômico, 1983. (IAC. Boletim Técnico, 81).

ROSENGAUS, R.B.; GULDIN, M.R.; TRANIELLO, J.F.A. Inhibitoru effect of termite fecal pellet on fungal spore germination. Journal of Chemical Ecology, v.24, n.10, p.1697-1706, 1998.

SANTOS, J.C.F. Mobilização de cálcio e alumínio em solos ácidos por compostos orgânicos hidrossolúveis de resíduos vegetais. Piracicaba, 1997. 72p. Tese (Doutorado) Centro de Energia Nuclear na Agricultura, Universidade de São Paulo.

SETA, A.K.; KARATHANASIS, A.D. Water dispersible colloids and factors influencing their dispersability from soil agregates. Geoderma, v.74, p.255-266, 1996.

SHEIKH, H.K.; KAYANI, Termite-affected soils in Pakistan. Soil Biology and Biochemistry, v.14, p.359-364, 1982.

SYLVESTER-BRADLEY, R.; BANDEIRA, A.G.; OLIVEIRA, L.A. de. Fixação de nitrogênio (redução de acetileno) em cupins (Insecta: Isoptera) da Amazônia Central. Acta Amazônica, v.8, n.4, p.621-627, 1978.

TANO, Y; LEPAGE, M. Les termites: dynamique des nids epiges et interactions avec les composantes du milieu. In: JOURNÉER HYDROPÉDOLOGIQUE DE L'ORSTON, Montpellier, 1989. Struture et fonctionamente hidropédologique d'un petit basin versant de savane humide. Paris: ORSTON,1990. p. 105-116. 
TISDALE, S.; NELSON, W.L.; BEATON, J.D.; HAVLIN, J.. Soil fertility and fertilizers. New York: Macmillan, 1993. cap.7, p.230-265: Soil and fertilizer potassium.

TOMÉ Jr., J.B. Manual para interpretação de análise de solo. Guaíba: Agropecuária, 1997. $247 p$.

VITTI, G.C. Avaliação e interpretação do enxofre no solo e na planta. Jaboticabal: FUNEP, 1988. 37p.

WALLER, D.A.; LA FAGE, J.P. Nutritional ecology of termites. In: SLANSKY Jr., F.; RODRIGUEZ, J.G. (eds.) The nutritional ecology of insects, mites and spiders. New York: John Wiley, 1987. p.487-532.

WATSON, J.P. The distribuition of gold in termite mounds and soil at a gold anomaly in Kalahari Sand. Soil Science, v.113, n.5, p.317-321, 1972.

-WOOD, T.G. Termites and the soil environment. Biology and Fertility of Soils, v. 6, p.228-236, 1988.

WOOD, T.G.; SANDS, W.A. The role of termites in ecossystems. In BRYAN, M.V. (Ed.) Production ecology of ants and termites. Cambridge: Cambridge University Press, 1978. p.245- 292.

WOOD, T.G.; JOHNSON, R.A.; ANDERSON, J.M. Modification of soils in Nigerian savanna by soil-feeding Cubitermes (Isoptera, Termitidae). Soil Biology and Biochemistry, v. 15, p.575-578, 1983. 